Historic, Archive Document

Do not assume content reflects current scientific knowledge, policies, or practices. 



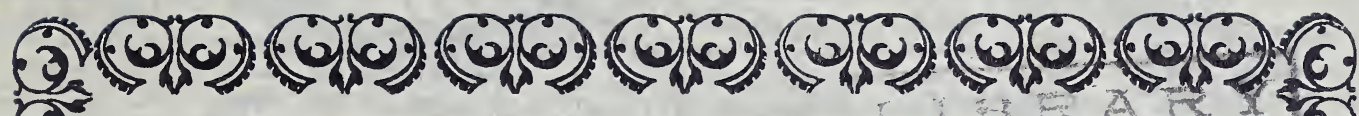
(3)

Hedge Lawn

3

3

Nurseries

3

3

ROANOKE

3

VIRGINIA

3

(3)

(3)

3)

(3)

3

3

(3)

(3)

(3)

(3)

(3)

Q

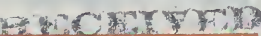

c.

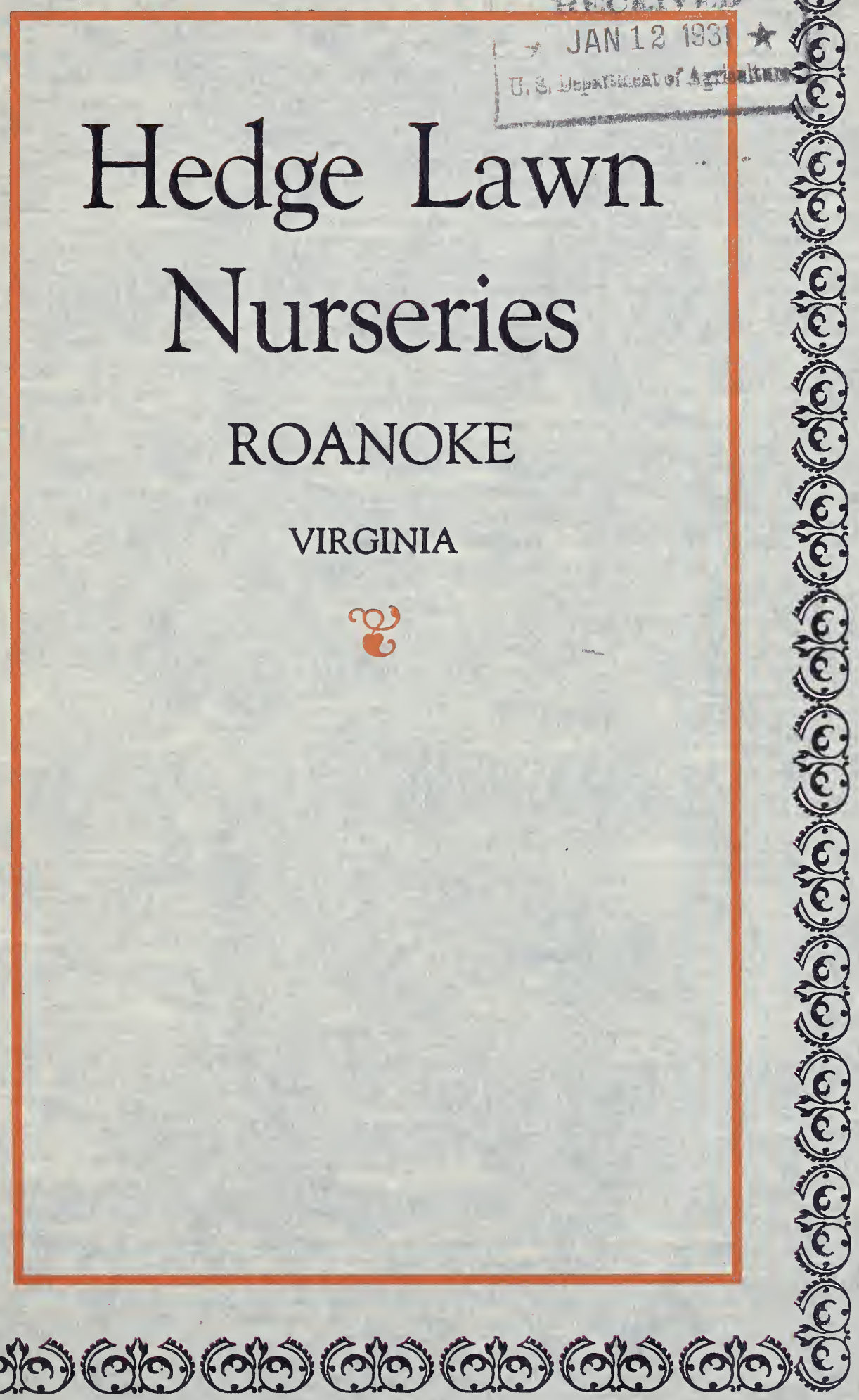




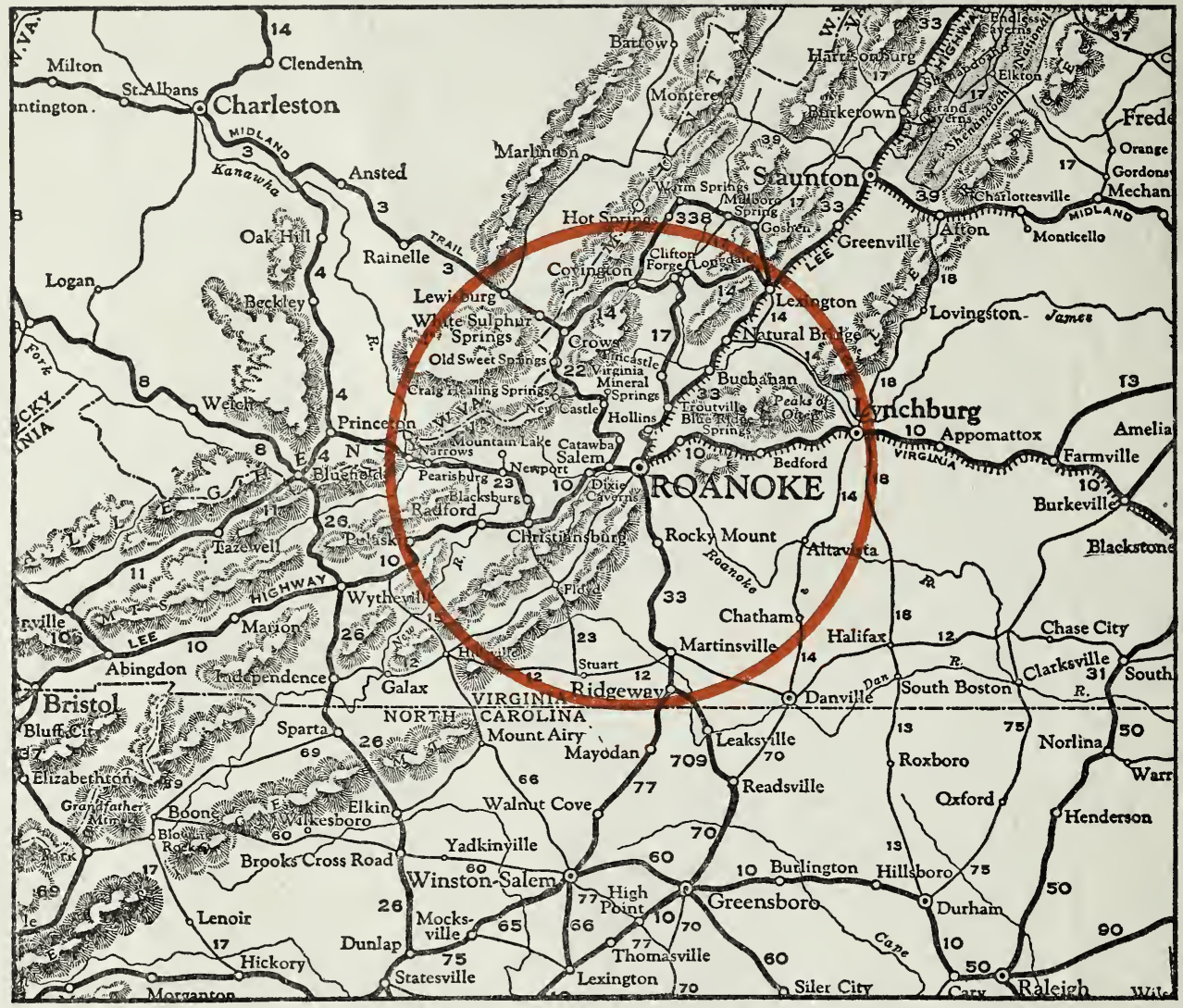

FREE DELIVERY BY TRUCK TO ANY POINT WITHIN CIRCLE

WE ALSO DELIVER BY TRUCK TO

BLUEFIELD, W. VA. WINCHESTER, VA. BRISTOL, TENN.

\section{CHARLOTTESVILLE, VA.}

AND

Intermediate Points for Which We Make a

Reasonable Charge 


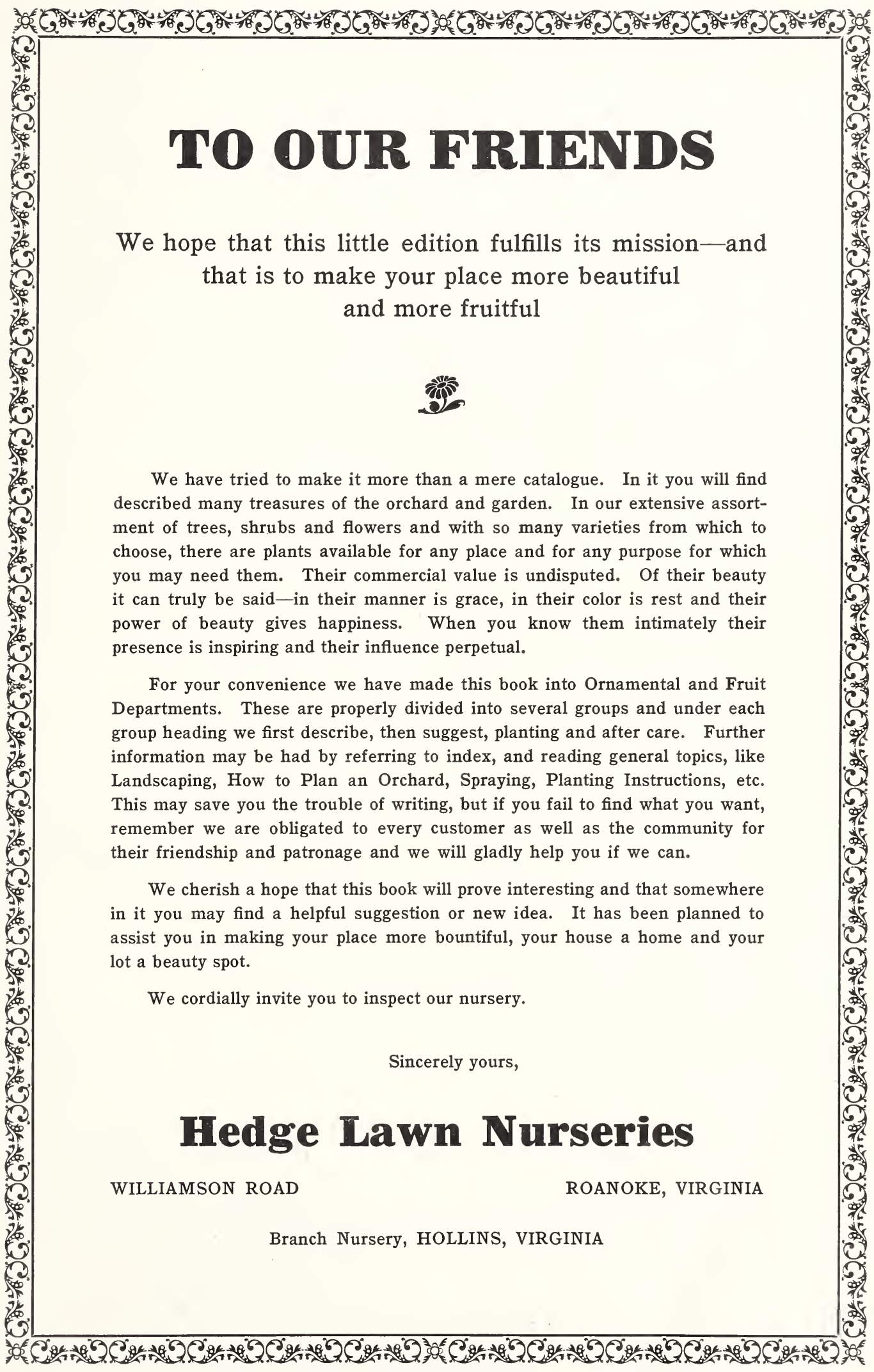




\section{OUR POLICIES AND SERVICE}

READ BEFORE ORDERING

Adjustments-Our chief aim is delivering to our customers-to you-a full measure of satisfaction, and any errors made in filling orders will be promptly and cheerfully corrected.

It is on this foundation that we have built our business and solicit your patronage. The coöperation we ask of you in establishing satisfaction is that you advise us immediately should an examination of your shipment disclose an error. Delays often make satisfactory adjustments impossible.

We have but few misunderstandings and believe that any differences which might arise in your dealings with us can be amicably straightened out.

In selling direct, without the expense of agents' commissions, we are enabled to give our customers a better value of goods and greater satisfaction.

Replacements-Everything that is humanly possible is done to insure the receipt by our customers of live, healthy stock that will thrive and give fine results if properly cared for.

The digging of stock, that is, cutting roots and moving the plants from one place to another, has in it a certain amount of risk as does a surgical operation. Nursery stock is perishable in nature, for the plants we sell are living things. In the transplanting of them a few may die.

Ninety per cent. of failures are due to causes which you will readily recognize are beyond our control, such as delay in transit, improper care after receiving, undue exposure during planting, improper setting, failure to prune, impoverished or unadapted soil, disease and injury with lack of subsequent care and attention. Not only do we carefully pack and ship live, healthy stock, but we instruct our customers as to the correct handling, planting and caring for the nursery stock they receive. Regardless of our many precautions a combination of the above circumstances may cause a tree to die although it possessed vigor and vitality when shipped.

Every bit of thought and knowledge we possess goes into the growing of our plants for a period of sometimes from two to fifteen years. It has cost us just as much to raise those that fail as it does those that grow. In view of our nominal prices and the fact that only live, healthy stock, properly prepared for shipment, leave our nursery, replacements without charge are not possible.

Guarantee-All stock sent out by us must not only be healthy but true to labeled name and as described in this catalogue.

Errors, of course, sometimes occur. We pride ourselves on conducting our business on the highest ethical lines. We deplore misrepresentation and carelessness alike, and the fact that our business is singularly free of adjustments speaks for the consistently satisfying service we render our customers.

Should, by any chance, a plant be found untrue to name we will gladly replace with the genuine or refund the purchase price. Beyond this we can assume no responsibility.
Substitution-Occasionally we find ourselves out of a certain variety. In such cases we always send the nearest match in color and season unless you instruct us, when placing the order, to make no substitution.

On many orders for fruits or ornamentals our intimate knowledge of varieties, soils and climate enable us to make changes which are profitable to our customers. We make no effort, however, to better a selection of varieties unless our customer gives us specific permission to do so.

Terms-Unlike most types of business, the average turnover of our stock is four and a half years. In other words, we are that length of time in getting our money back even when the goods are sold on a cash basis. For this reason our terms are cash with order.

\section{WHEN TO PLANT}

When is the best time to plant? This question is asked more than any other. There is no best time. Several conditions make it impossible to name either spring or fall. The best time to plant hardy things is when your soil is in the best condition to receive the plants. This preparation is the most necessary. The temperature of the ground changes little, fall or spring, after you get under the surface a few inches. All things being equal, fall has advantages over spring. The cut roots heal over during the winter, the rains usually firm the soil about the plant and with the first breath of spring air your tree is on your grounds ready to start. But the spring planter doesn't have to risk winter injury on the tender plants; he has the long winter evenings to plan his requirements and the soil is usually a little easier to dig and prepare.

A state certificate of inspection accompanies each shipment, assuring its freedom from insect pests and disease. We are members of the American Association of Nurserymen.

\section{BRIEF PLANTING INSTRUCTIONS}

We send out planting instructions with each order. Some cultural hints are given under each heading throughout the catalogue. Briefly, this is what you should do:

On arrival of trees, place in a protected place, keeping moist if held for a day only, else bury roots in ground at once.

Pruning is necessary. General rule is to cut off one-half to two-thirds the length of the lateral branches. This balances loss of root system necessary in digging the tree. Remove all label wires.

Plant carefully. Dig ample holes to take roots without crowding. Plant not more than an inch or two deeper than they formerly stood. Work fine soil into the roots, be sure there are no air pockets and tamp earth solid to insure contact with every root. Water, if possible, before applying the top three inches. 
Mulching or cultivation is necessary if good growth is expected. Both conserve the moisture, which is very essential.

Watering, sprinkling and spraying are of little value during times of drought. Remember the roots of most plants are buried eight to eighteen inches in the soil and it takes a good soaking to reach them. Let the hose run slowly for an hour or so-it pays.

\section{LET US SOLVE YOUR LANDSCAPE PROBLEMS}

Have you hesitated about beautifying your lawn because you hardly knew how to go about it? The proper selection and arrangement of plants in some cases does take more time and study than some busy folks can find to give to the subject. Just what plants to use to screen your (or your neighbor's) clothes yard from the house; to give your lawn seclusion; to relieve the bare look of the house foundation-these are among the problems that, perhaps, confront you. We have endeavored to make this book as helpful as possible and we feel confident the lists, descriptive matter and illustrations will point the way to the solution of many problems. Some, however, cannot be dealt with in generalities.

For the solution of individual problems we maintain men well trained in plant adaptabilities and arrangements. They will gladly give you our ideas on plant selections and arrangements, together with estimate of cost. This is done in either of two ways:

Personal calls to go over the problem right on the lawn or Letter Aid Service is offered to patrons at more distant points. Through it we are able to give you much the same service as is rendered through a personal call, for with a detailed description of your problem, a sketch showing dimensions and existing features and a photo or two, if available, we can readily visualize it, and give you our ideas and estimate.

\section{THE SECRETS OF SUCCESSFUL LANDSCAPE GARDENING}

Start out with a definite object in view and plan accordingly.

Locate your walks and roadways, arranging them for service and beauty.

Avoid straight lines and sharp angles if possible. Graceful curves are more pleasing to the eye.
If shipment is wanted by parcel post, be sure to include in your remittance sufficient to cover postage charges.

Plan to leave the center of lawn unobstructed, planting the borders with masses of shrubs and trees.

Remember, in arranging your shade trees on the lawn, your idea should not be to play checkers with them but to "frame" the house and not hide it. Always leave the center open as it makes the approach more inviting.

Background, or sky line, is a feature not half appreciated. Given a proper setting a cottage will often be more attractive than a poorly planted mansion. Plant heavily behind and to the rear sides of your home if on a big lawn.

Avoid too much variety in mass planting. Alternating or "salt and pepper" arrangement is not nearly so effective as grouping plants of each kind. Where space permits, at least five plants of a single kind is suggested.

For front line or border planting especially, choose few varieties and plant more of them. The result will be more pleasing. Plant the taller things in the back of the border with the lowergrowing ones alternating and the border plants in curves or groups.

For the foundation remember always-height in the corners, immediately in front of pillars and at the bare wall spaces. Under the windows, low or medium plants only.

\section{PLANTING THE GARDEN}

You'll find few diversions more delightful than the simple acts of planting and caring for a garden. If you have not already, now is the time to plant those varieties that you have seen this summer on other lawns and envied for your own. If you haven't, no better time will ever come to tap the treasure-trove of beauty and of richest enjoyment that exists right at your very doorstep.

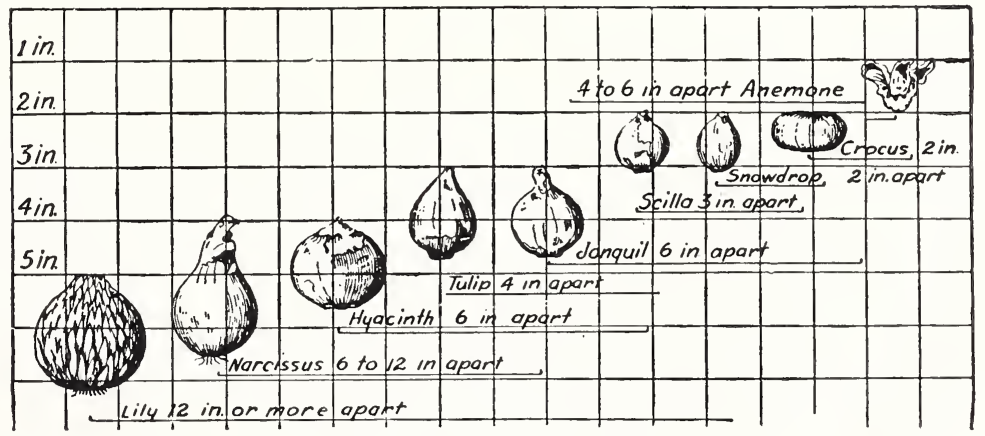

SCALE FOR PLANTING BULBS 


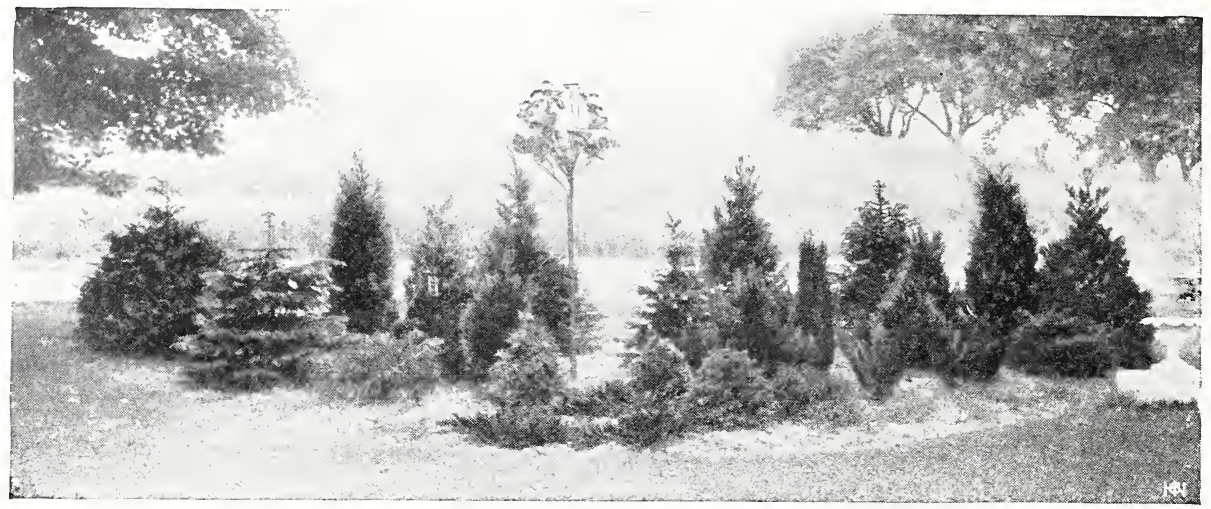

A GROUP OF SPECIMEN EVERGREENS

\section{EVERGREENS}

\section{ARE IMPORTANT IN ANY PLANTING}

Green of every shade and hue, charmingly contrasted with blue, gold and gray, their foliage is always pleasing. Pyramidal or erect, globular or spreading, you can find forms for every fancy. For groups or screening, in shelter planting or hedges, you have nothing quite to equal them. In summer they are attractive, in winter they offer a comforting note to the bleak landscape and under the weight of ice and snow their great drooping branches of green seem to cheer.

Out in the lawn, the larger growing Pines, Spruces and Hemlocks suggest a permanency and a grandeur that cannot be duplicated with other planting materials. For small premises there are appropriate varieties. As backgrounds, hedges and specimens you will find plants suitable for every use. In landscape work they simply have no rivals. They are so wonderful because of their beauty throughout the four seasons of the year.

Their most popular use, of course, is for doorstep or foundation planting. No home is now complete without something to break the bare walls or soften the harsh lines. The day of cannas is past, persons demand something more permanent and more lasting than a few weeks of summer blossom and foliage. Evergreens fill every requirement. They are hardy, they are enduring and their beauty permanent. Their habits of growth, their various forms and interesting foliage enable any one to choose, no matter how fastidious, varieties that will be pleasing in effect and congenial of location.

\section{PLANTING SUGGESTIONS}

Before you dig your holes or loosen the burlap (as all evergreens should be handled with balls of soil intact) set them up in arrangement as planned and move them about, view them from different angles so as to get the very best effect. When planting, the burlap should be loosened and laid down in the hole or removed, or if the ball of soil is broken, then the hole should be partially filled with earth and then the top portion of the burlap cut away with a sharp knife. By all means tread the soil firmly about the roots. The general planting directions also apply here. Watering is very necessary during periods of drought and especially the first year. Remember the caution to water copiously these deeply set plants-and one good soaking is worth a dozen light sprinklings.

\section{PRUNING}

At planting time evergreens seldom need pruning. If well grown like ours they are shapely and when handled with balls of soil they should grow off without trouble. However, in a year or so some varieties are inclined to grow "open." Then shearing may be done with hedge tools, clipping the young growth, preferably not further than that made the previous season. This causes the inner branches to advance, making a very close and compact plant, thus hiding the unsightly interior of open trees.

ARBOR VITAE, BERKMAN GOLDEN, T. orientalis aurea nana-This is, without doubt, the showiest of all the Arbor Vitae family. The color is an unusually attractive bright green and is striking in appearance. Does especially well with us and should be in every planting.

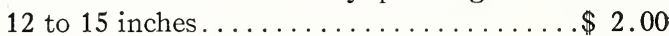

18 to 20 inches................. 3.50

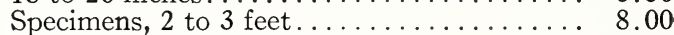

Specimens, 3 to 4 feet............. 15.00

ARBOR VITAE, ORIENTAL or CHINESE, T. orientalis - This has the typical pressed foliage of the Arbor Vitae family, but is inclined to branch erect forming in "folds" about the stems of the plant. It is different from the other varieties in character of growth and appearance. It grows very rapidly and can be used where mass effect is wanted, as a specimen or in a hedge. It shears especially well and it is often necessary to prune it to make it real compact as it is inclined to grow open.

18 to 24 inches................. \$ 1.00

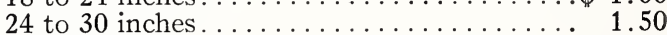

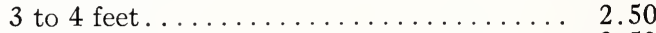

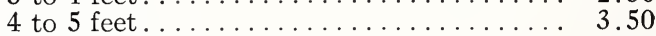

5 to 6 feet.................. 5.00

8 to 10 feet. . . . . . . . . . 


\title{
EVERGREENS
}

ARBOR VITAE, PYRAMIDAL, T. occidentalis pyramidalis-This is strikingly attractive, being perfectly pyramidal in shape, spreading very little at its base and retaining the shape without shearing. The color is deep, rich green and, like all Arbor Vitaes, is easy to transplant. For corners, in front of pillars, center or background of group plantings, there is hardly an evergreen of the dwarf variety that is quite so popular.

18 to 24 inches

$\$ 2.00$

2 to 3 feet

3.00

3 to 4 feet

3.50

4 to 5 feet

5.00

5 to 6 feet.

\section{PLUME RETINISPORA}

(Retinispora Plumosa)

\author{
FOR PRICES AND DESCRIPTION
} SEE PAGE 8

\section{SPECIAL 12 EVERGREENS (2 to 3 Feet)}

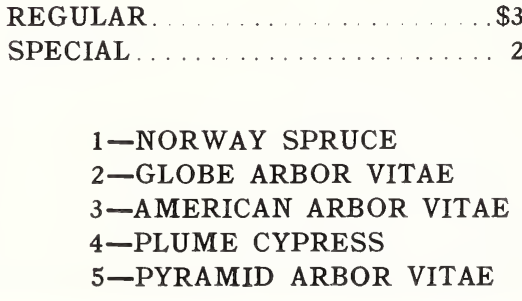

REGULAR

SPECIAL

\section{1-NORWAY SPRUCE \\ 2-GLOBE ARBOR VITAE \\ 3-AMERICAN ARBOR VITAE \\ 4-PLUME CYPRESS \\ 5-PYRAMID ARBOR VITAE}

( Two each of the above Evergreens, except the American Arbor Vitae; four of these are included

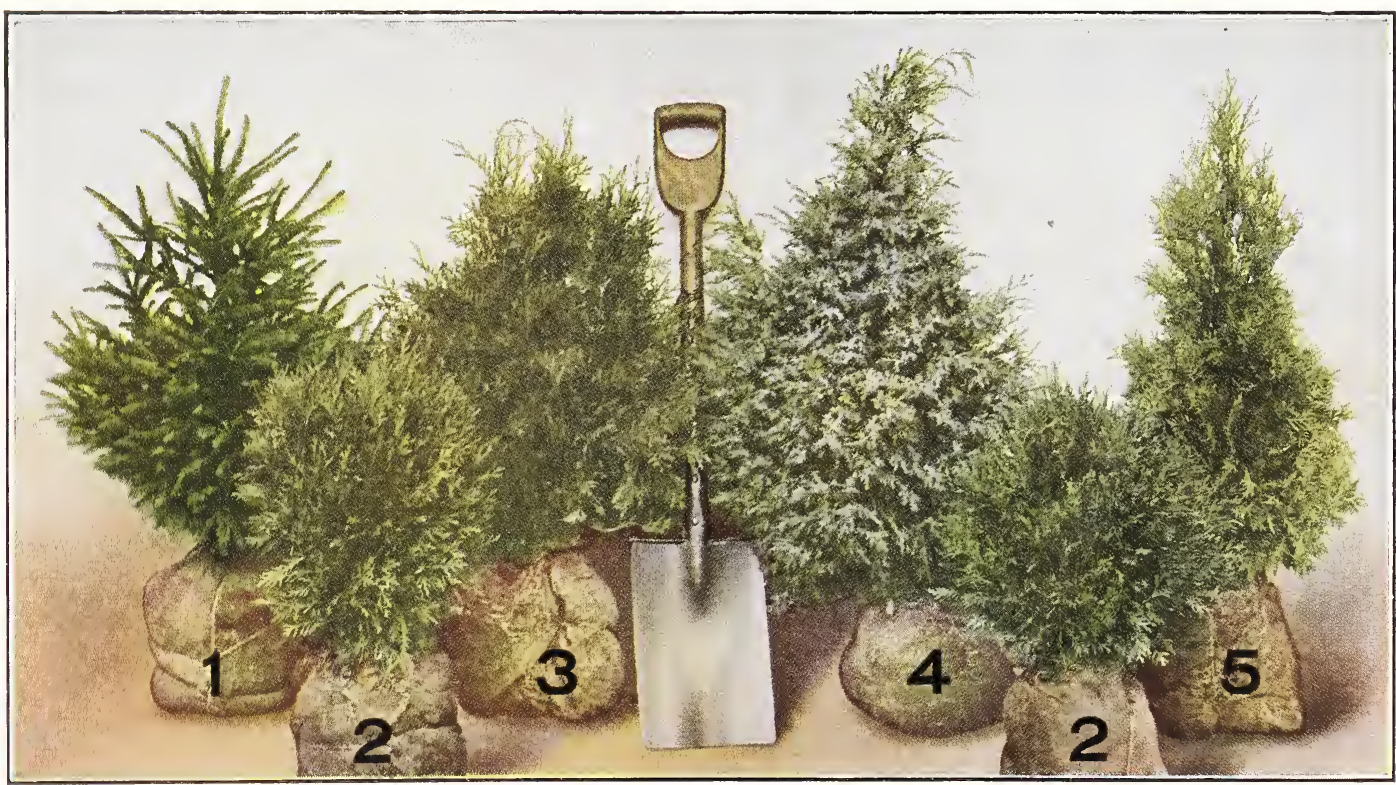




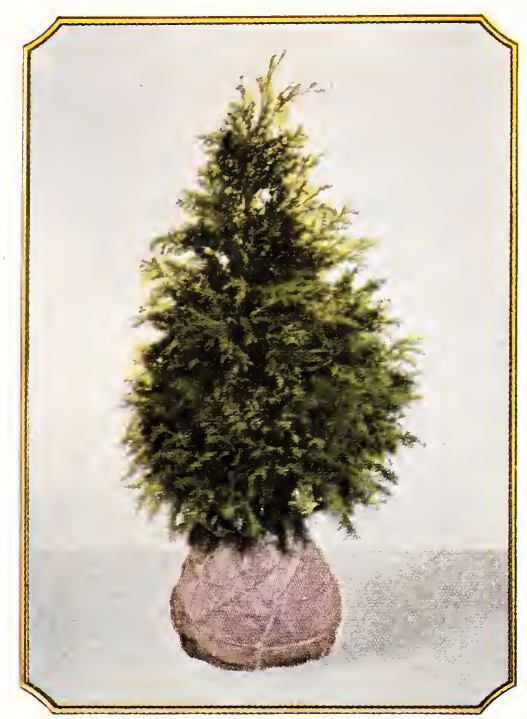

ARBOR VITAE, AMERICAN, Thuja Occidentalis-One of the most popular evergreens because of its easiness to transplant, growing kindly under adverse conditions, and as a specimen or hedge plant it is very attractive. It is inclined to be conical in habit of growth and while it is not as green in color during the winter as some of the other varieties it is one of the most popular because of its many good quantities.

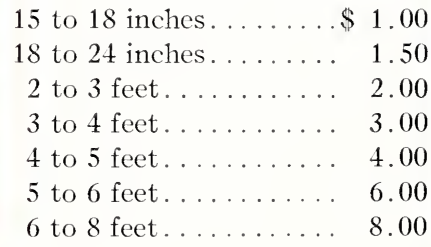
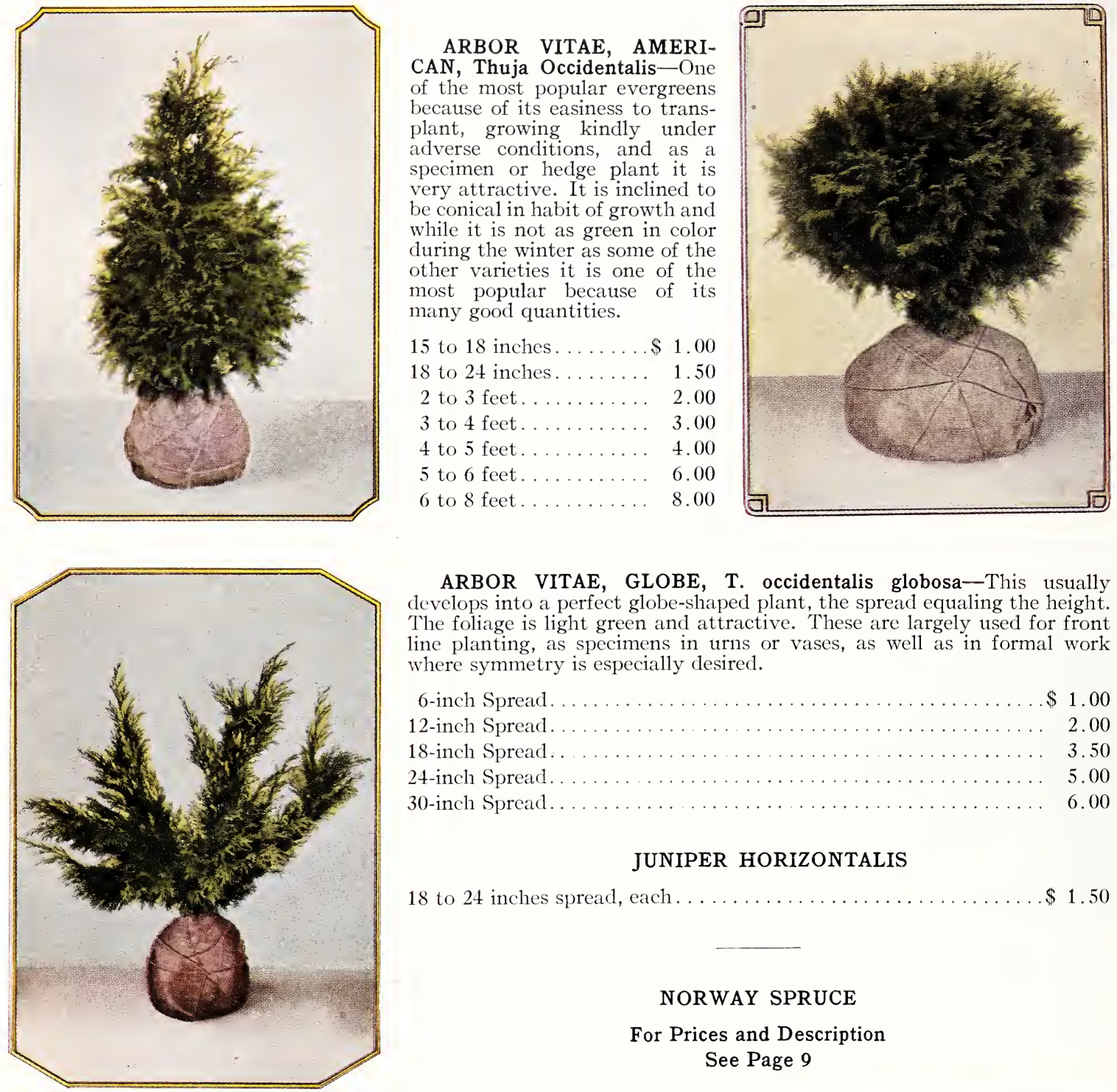

ARBOR VITAE, GLOBE, T. occidentalis globosa-This usually develops into a perfect globe-shaped plant, the spread equaling the height. The foliage is light green and attractive. These are largely used for front line planting, as specimens in urns or vases, as well as in formal work where symmetry is especially desired.

6-inch Spread

$\$ 1.00$

12-inch Spread.

2.00

18-inch Spread.

3.50

24-inch Spread.

5.00

30-inch Spread. . .

6.00

\section{JUNIPER HORIZONTALIS}

18 to 24 inches spread, each . . . . . . . . . . . . . . . . $\$ 1.50$

\section{NORWAY SPRUCE}

\section{For Prices and Description} See Page 9

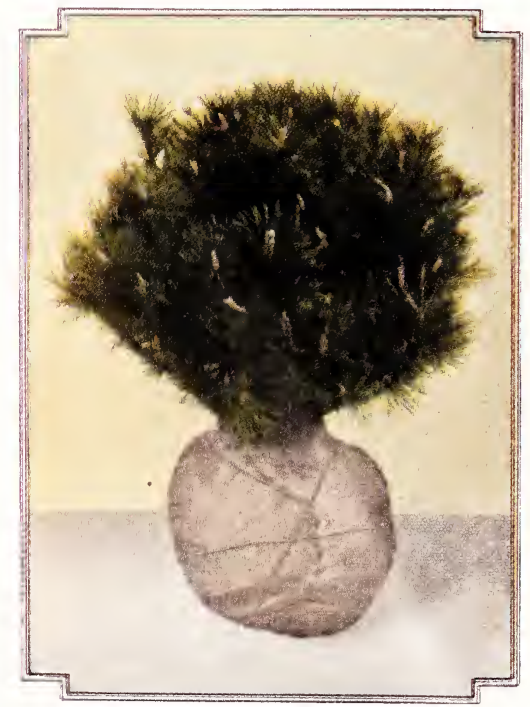

P I N E, M U G H O. Pinus montana mughus-This is an excellent dwarf pine, being globe shaped and erect branching. It is very attractive, especially in spring when the new growth, which seems like miniature candles, completely covers the bush.

8 to 10 inches

12 to 18 inches
$\$ 2.00$ 3.50

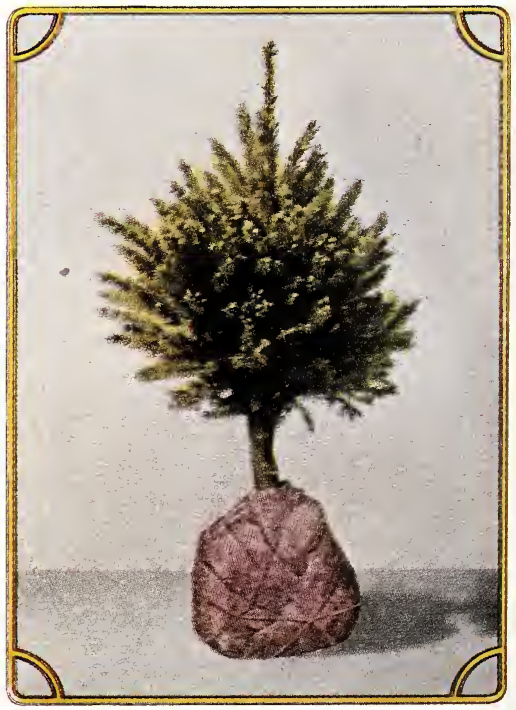




\section{T. or COMPACTA, COMPACT CHINESE ARBOR VITAE}

15 to 18 inches................. 1.50

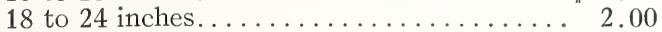
24 to 30 inches................. 2.50

ARBOR VITAE, SIBERIAN or WARE'S, T. occidentalis waureana-This is a small globe variety and its unusually dark green color makes it very useful. It is the darkest green of all the American Arbor Vitaes. It can be sheared to a perfect globe, though if left to develop naturally it is oblong.

2 to $2 \mathrm{r} / 2$ feet................ 3.50

ARBOR VITAE, ELLWANGER'S, T. occidentalis ellwangeriana-This has very fine cut foliage and does not exactly resemble the "pressed" leaves that characterize the other varieties. This is very compact growing and has a soft, feathery appearance not found in other evergreens.

18 to 24 inches...............\$2 2.00

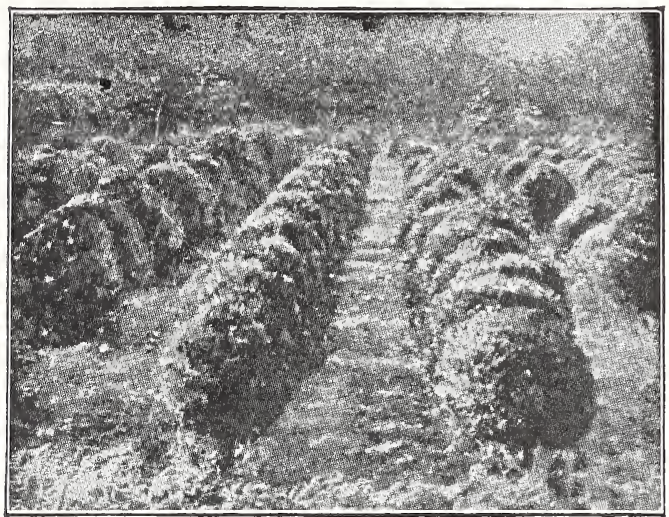

A BLOCK OF AMERICAN ARBOR VITAE

ARBOR VITAE, GOLDEN, T. occidentalis lutea-This has bright yellow foliage in the growing season and is especially fine where contrast in color is wanted. It is distinctly pyramidal in shape, being broad at the base.

18 -inch.....................\$2 . . . . . . . 30-inch.

\section{ROSENTHALII ARBOR VITAE}

18 to 24 inches.................. \$ 2.50

AUREA CONSPICUA (biota), $7^{\prime}-\mathbf{8}^{\prime}$-Gold Spire Arbor Vitae. Golden yellow in spring, bronze yellow in winter. Distinctive.

2 to 3 feet. .

$\$ 3.50$

3 to 4 feet.

5.00

TOM THUMB ARBOR VITAES. $\$ 1.00$ to $\$ 3.00$

\section{T. or PYRAMIDALIS, PYRAMIDAL} ARBOR VITAE (Baker's)

3 to 4 feet...................\$ 5.00

FIR, NORDMANN'S. Abies nordmannianaA pyramidal tree with small dense needles, dark green on surface with silvery tones on under side. It is a little slow to get started but when it has developed its tap root will make a fine specimen plant.

18 to 24 inches.

$\$ 4.00$
FIR, SILVER or WHITE. A. concolor-This tree has unusual light bluish green foliage and rivals the Blue Spruce in attraction in the spring. It is pyramidal in shape and will grow quickly when it becomes established. One of the best evergreens for the lawn.

24 to 30 inches................\$3 . 50

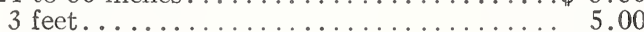

4 feet..................... 15.00

5 feet...................... 20.00

DOUGLAS FIR

HARDY, ONE OF THE BEST

18 to 24 inches................... \$ 1.50

2 to 3 feet................... 3.50

3 to 4 feet $\cdots \cdots \cdots \cdots \cdots \cdots \cdots \cdots \cdots \cdots \cdots \cdots \cdots \cdots \cdots$

4 to 5 feet.................... 6.00

8 to 10 feet.................. 15.00

\section{HEMLOCK}

TSUGA CAROLINIANA, Carolina HemlockCarolina Hemlock is unique in habit, with dark, dense tufted foliage on sweeping, pendulous branches with a "Japanese effect." It is hardier and more adapted to trying city atmospheres than the Canadian Hemlock and seems to thrive in southern latitudes where the latter becomes thin, yellow and unsightly.

2 to 3 feet.................... 55.00

4 to 6 feet.................... 10.00

HEMLOCK, Tsuga canadensis-We consider Hemlock the very best of all the evergreens. It grows rapidly in the open lawn, in confined places it adapts itself to all conditions and, if kept sheared, can be well used as a foundation plant. If left to develop naturally, it has sweeping pendulous branches that are most graceful and when sheared it has a soft, billowy appearance that cannot be duplicated with other evergreens. The foliage is

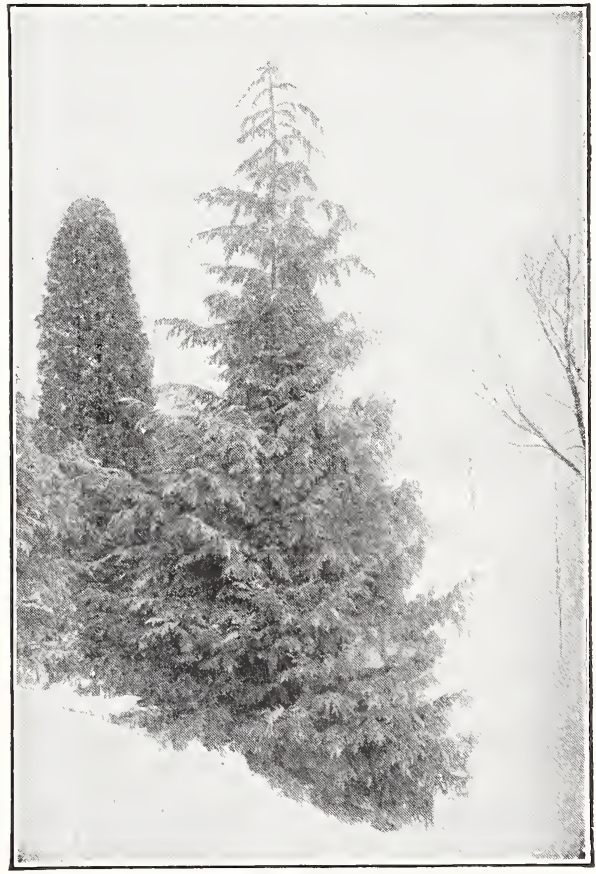

CANADIAN HEMLOCK 


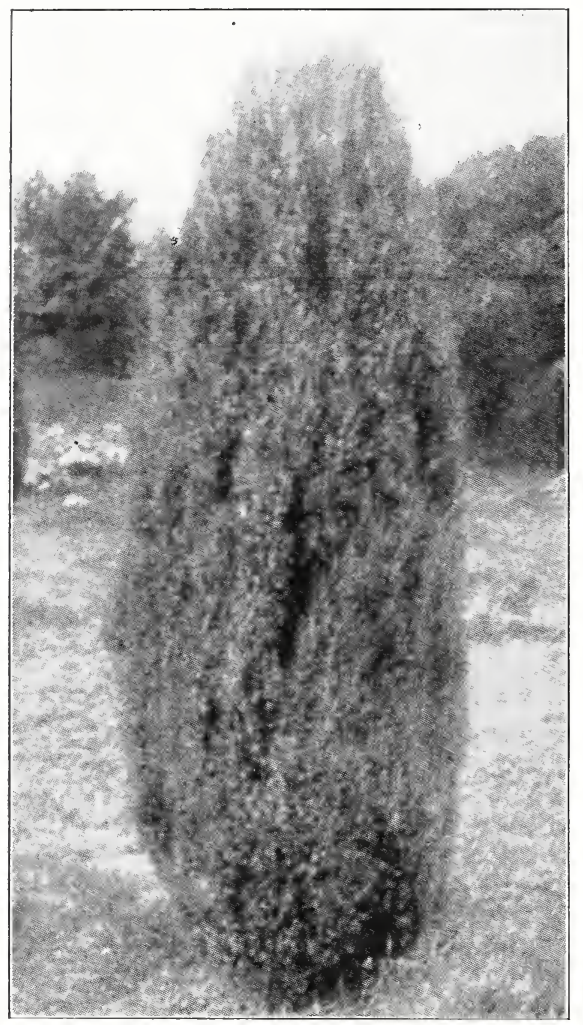

IRISH JUNIPER

always a very deep green and as it will grow in all exposures and under adverse circumstances it is more largely planted than any other evergreen. We have a saying here, "When in doubt, plant a Hemlock."

18 to 24 inches.

$\$ 2.00$

2 to 3 feet

3.00

3 to 4 feet

4.00

5 to 6 feet

12.50

JUNIPER, IRISH. J. communis hibernica-This is a decided columnar form and immediately at-

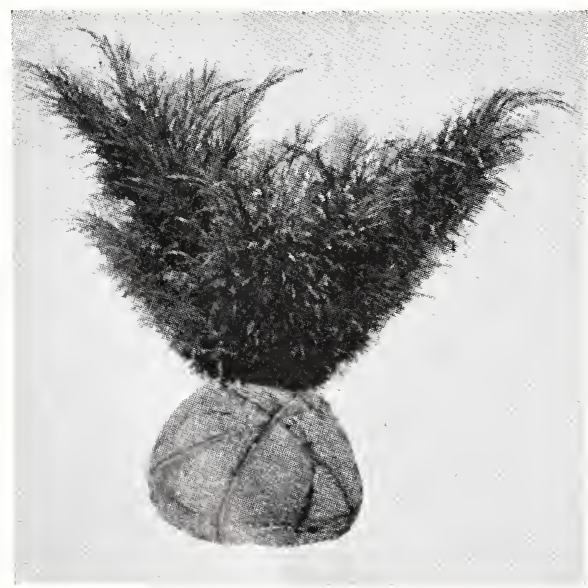

JUNIPERSUS SABINA (Savin Juniper) tracts attention. The foliage is a glaucous green. For formal work, especially in contrast with other plants, it has decided advantage over anything you can use for such work. It is very slender in habit of growth and needs no shearing.

Irish Juniper, 2 feet...............\$2 2.00 Irish Juniper, 2 to 3 feet. . . . . . . . . . . 2.50 Irish Juniper, 3 to 4 feet. . . . . . . . . . . . . . . 3.50 Irish Juniper, 5 to 6 feet. . . . . . . . . . . . 6.00

JUNIPER, SAVIN'S. J. sabina-One of the best. Spreading, fan-shape habit, of pleasing color of dark green. Stands the city dust, soot, etc., exceptionally well.

15 to 18 inches Spread.... . . . . . . . .\$2 2.50

18 to 24 inches................. 3.50

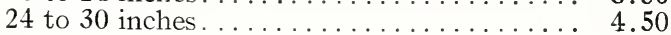

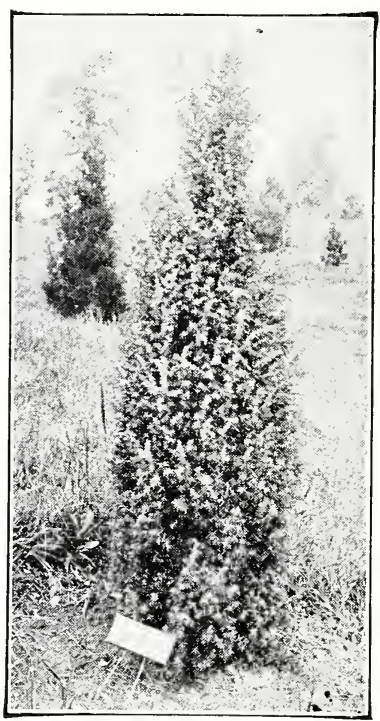

SWEDISH JUNIPER

JUNIPER, SWEDISH. J. communis suecicaThis is another columnar form of gray-green foliage and unusually attractive in the winter. Where formal effects are wanted this can be used. It is not as quick in growth as Irish Juniper and in limited areas is preferred.

18 to 24 inches..................\$2 2.50

JUNIPER, PFITZER'S. J. chinensis pfitzeriana-This is the most popular of all the spreading types. Its habit of growth, its pendulous branches and attractive foliage is strikingly beautiful. The branches are horizontally spreading and the terminals slightly drooping. It lays close to the ground and for edging larger plantings there is nothing superior. Flowing lines are especially valuable in landscape planting and this juniper seems to fill this requirement better than any other. The foliage is a gray-green, both summer and winter, and, because of its ability to withstand the soot and dust of cities, will thrive where others fail. Another advantage is that it lends itself to severe pruning in case it outgrows its location.

15 to 18 inches Spread.............. 2.50

18 to 24 inches..................... 3.50

24 to 30 inches................. 4.50

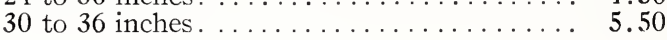


JUNIPER DOUGLASI. Waukegan Juniper-

Evergreen. Long branches trailing along ground. Steely-blue foliage. A splendid ground cover; also effective among rock. Distinct purple hue in winter. 18 to 24 inches..................... $\$ 2.50$

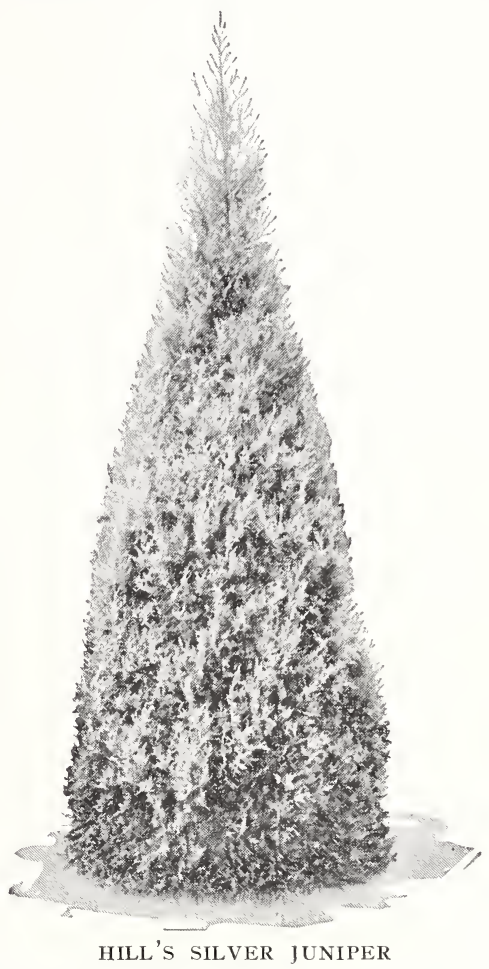

HILL'S SILVER JUNIPER. Juniperus scopulorum-Beautiful silvery-blue color. Narrow, compact and symmetrical. It has one single stem, in contrast to some varieties of junipers with several stems. This makes it safe from heavy snows and wind. The inner foliage does not turn brown. New introduction by D. Hill. This is the seedling form containing both blue and green trees.

24 to 30 inches.

$\$ 3.00$

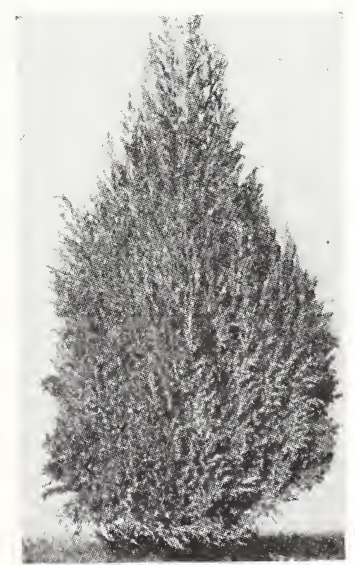

JUNIPERUS EXCELSA STRICTA (Greek Juniper)

Greek Juniper, 18-inch. . . . . . . . . . . . . \$ 3.50

Greek Juniper, 24-inch. . . . . . . . . . . . . 5.00

\section{JUNIPER}

English Juniper, 18 to 24 inches......... .\$2 2.50

English Juniper, 3 feet. . . . . . . . . . . . . . . 4.00

\section{IMPORTANT}

Prune evergreens when they are growingbetter just as the spring growth comes on and at least before it becomes hard in July.

The principal trouble is the dog. Tie up the pup, as canines and conifers don't mix, or else plant something on the front row in protection.

\section{THE RETINISPORA OR JAPAN CYPRESS}

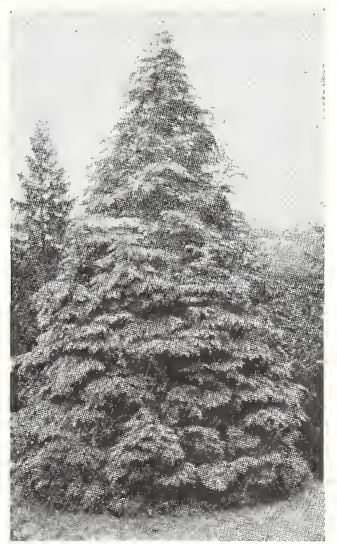

CHAMAECYPARIS LAWSONIANA

$$
\text { (Lawson Cypress) }
$$

15 to 18 inches..................... \$ 2.00

18 to 24 inches....................... 2.50

2 to 3 feet....................... 4.00

3 to 4 feet....................... 5.00

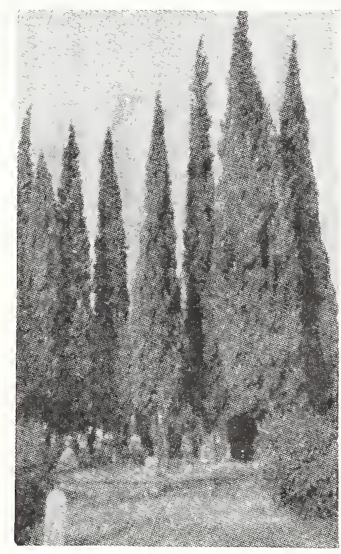

CUPRESSUS SEMPERVIRENS STRICTA (Italian Cypress)

Cypress, 18 to 24 inches.

$\$ 2.00$

Cypress, 4 feet.......................... 5.00

Arizona Cypress, 3 feet............... . 4.00

Arizona Cypress, 4 to 5 feet........... 8.00 
SQUARROSA. Veitchii-Light bluish-green foliage, which is spreading and prickly; very dense growth.

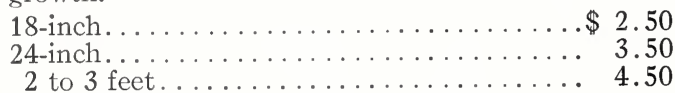

RETINISPORA, Pea Fruited or Sawara Cypress. Chamaecyparis pisifera-The foliage of this resembles the Arbor Vitae very much and the tree d e ve 1 op s decidedly erect with very graceful branches. When sheared especially does the foliage develop its true color. It is very lacy in appearance with a silvery color on the underneath side. It is a fine plant in the foundation where a heavy plant is wanted and on the lawn it makes an attractive specimen.

18 to 24 inches.

$\$ 2.50$

R E T I N I S P O R A, Golden Pea Fruited. C. pisifera aurea-This has all the characteristics of the green form described above except that the foliage is a very light green or bordering on yellow. Both of these will do well in city planting where more tender evergreens fail.

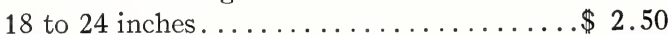

2 to 3 feet.................... 3.50

3 to 4 feet................... 4.50

RETINISPORA, Plumed or Plumed Cypress. C. pisifera plumosa-The foliage of this is a grayish green, very fine cut, and has a feathery appearance. It resembles a fine cut fern frond at certain stages of its development. Pyramidal in habit of growth and if kept sheared, as all varieties of this family should be, in foundation planting it will make a wonderful specimen.

Plumed Cypress, 24-inch............\$3.00

Plumed Cypress, 2 to 3 feet........... 3.50

RETINISPORA, Golden Plumed. C. pisifera plumosa aurea-In habit of growth and appearance, is like the green form precedingly described. The young foliage is very light green bordering on yellow and for contrast planting for foundation or lawn groups is one of the most popular.

15 to 18 inches................\$2.00

24 -inch........................ 3.00

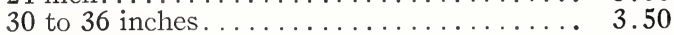

3 to 4 feet................ 5.00

\section{RETINISPORA OBTUSA NANA}

18 to 24 inches.................\$5.00

RETINISPORA FILIFERA AUREA. Golden Thread Branched Cypress-Evergreen. Very bright, conspicuous, golden-yellow. Grows more slowly than preceding.

18 to 24 inches.

\section{STATELY BEAUTY WITH CONIFERS}

Just as different effects in building architecture are obtained with different materials, so are different plants, employed in planting the home grounds. Tall conifers produce the stately effects found in classical lines of architecture. Plant them in corners, at formal entrances, against tall buildings, and in groups at points which form a view from convenient windows. Italian or Arizona Cypress is the variety much used to accent the corners.

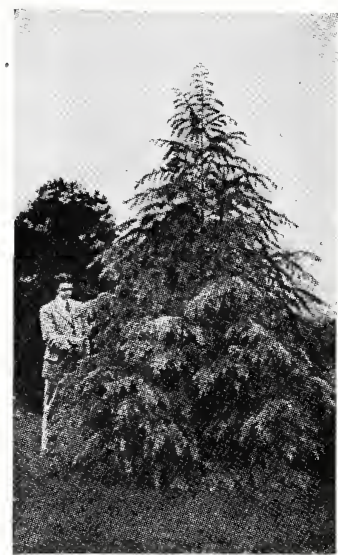

CEDRUS DEODARA

(Deodar Cedar)

\section{CEDARS (Cedrus)}

This group includes the familiar and characterful red cedar, the cedrus deodara, and the blue cedarthe first, a native of the South, and the others, plants in great demand now for prominent positions as specimen lawn plants.

DEODAR (c. deodara). Himalayan Cedar.Beautiful, pyramidal, large evergreen growing from broad base to point at tip. Branching horizontal, foliage silver or bluish. A striking beauty on the lawn as specimen or in groups. Highest quality. Adds grace and beauty to the finest grounds. Perfectly adapted to the South, although a native of Asia, the Indian Cedar of Kipling's writings.

18 to 24 inches.................\$2.00

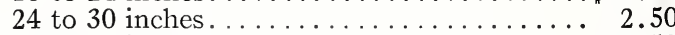

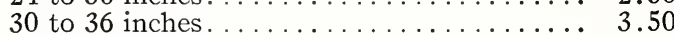

40 to 48 inches............... 5.00

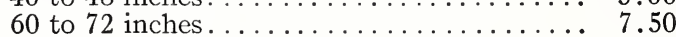

\section{THE SPRUCES}

PICEA, Pungens--Colorado Spruce. Sharp leaves are bluish to dull green and rather thicker than usual. Branches horizontal, in regular whorls.

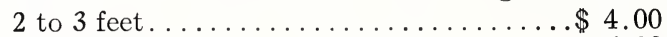

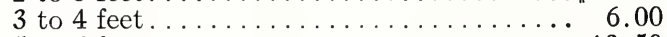

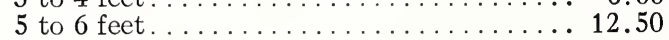

PICEA, Glauca-Colorado Blue Spruce. From selected specimens only. A bluer form of the preceding, and in many ways just as effective as the Koster variety following.

15 to 18 inches..............\$3.50

2 to 3 feet....................... 15.00

3 to 4 feet (specimens) . . . . . . . . 25.00

5 to 6 feet (specimens) . . . . . . . . . . 40.00

6 to 8 feet (specimens) . . . . . . . . 60.00

SPRUCE, KOSTER'S BLUE. Picea pungens kosteri-Its striking blue color is noticeable as far as it can be seen. It is best used as a specimen with a dark background or in groups where contrast is to be had. The past few years it has become very scarce and the plants are decidedly expensive. 24 to 30 inches. . . . . . . . . . . . .\$ 15.00

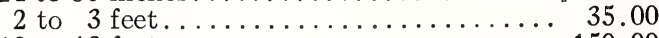

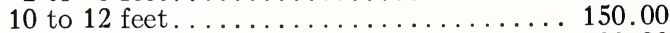
12 to 15 feet.................. 200.00 


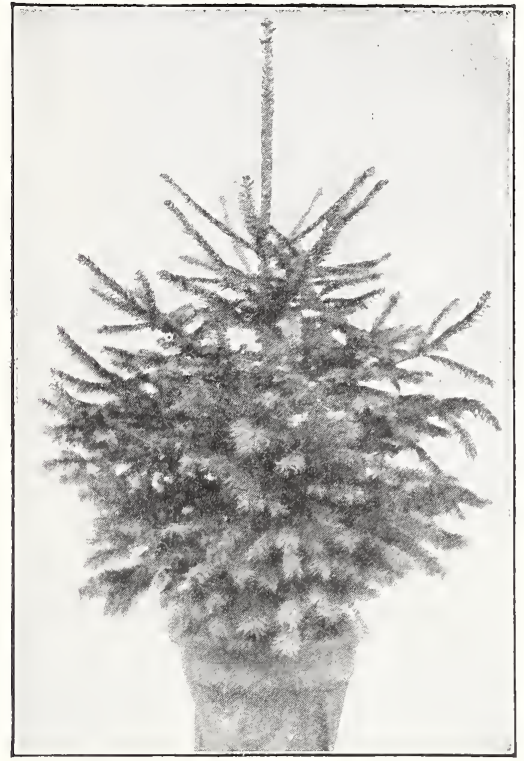

NORWAY SPRUCE-P. EXCELSA

SPRUCE. Norway P. Excelsa-This has been the most popular of the spruce family as it is easy to transplant, hardy and grows rapidly. Pyramidal in shapc and when used as a specimen is very fine. For screcn, wind break and hedges they are equally appropriate. The needles are dark green in color. Norway Spruce has been largely planted and really has no serious fault.

12 to 18 inches................ $\$ 1.00$

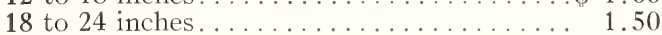

2 to 3 feet.................... 2.50

4 to 5 feet................. 6.00

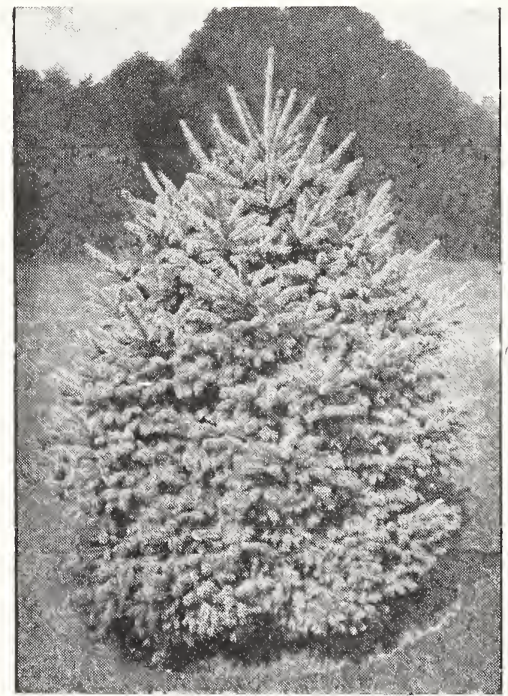

BLACK HILL SPRUCE

\section{BLACK HILL SPRUCE}

24 to 30 inches.

$\$ 2.50$

2 to 3 feet........................ 4.50

3 to 4 feet........... 8.00

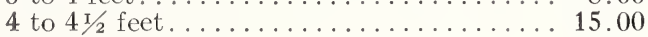

SPRUCE, WHITE. Picea canadensis-This is a very hardy evergreen with light green foliage and similar in many respects to the preceding variety except that it is decidedly slower growing in our locality and can safely be used where a medium sized or small tree is wanted.

24 to 30 inches.................\$ 2.50

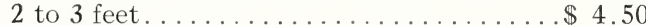

3 to 4 feet.................... 8.00

4 to $4 \mathrm{r} / 2$ feet. . . . . . . . . . . . . 15.00

\section{SCOTCH PINE, PINUS SYLVESTRIS}

2 to 3 feet.................... 3.00

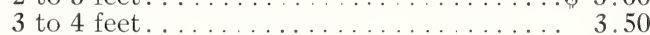

4 to 5 feet................... 6.00

RESINOSA - Norway or Red Pine. Very ornamental; is quite hardy and of vigorous growth; the needles are lustrous green, long and most often in pairs, contrasted by the russet-colored, stubby cones.

4 to 5 feet

$\$ 10.00$

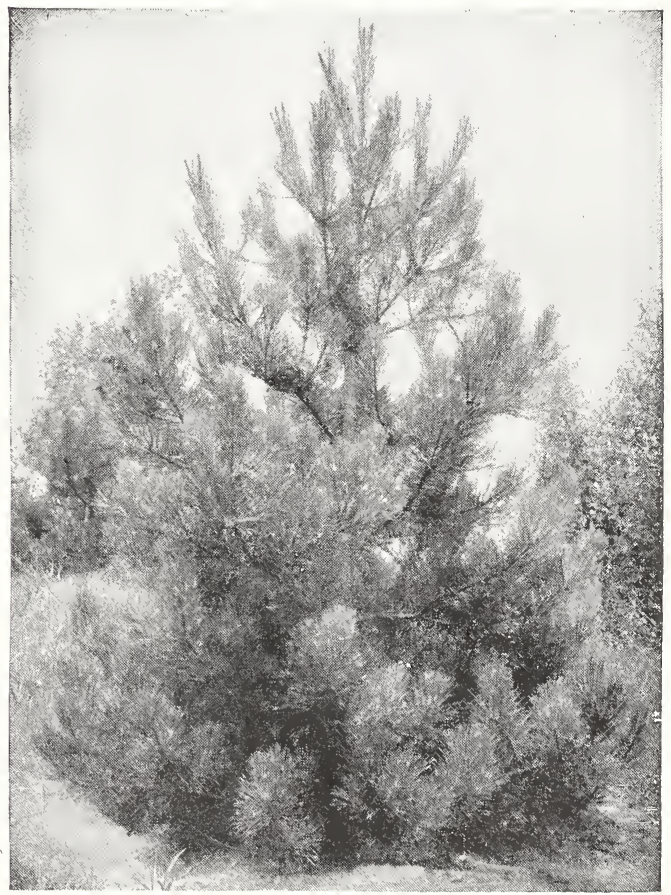

AUSTRIAN PINE

NIGRA AUSTRIACA - Austrian Pine. A robust, stately tree of rapid growth, and very hardy. Stiff, long, dark green leaves in pairs. The winter buds are whitish and long.
2 to 3 feet
$\$ 4.00$
3 to 4 feet.
5.00

\section{JAPANESE BLACK PINE}

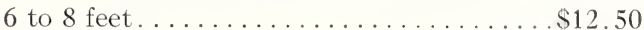

\section{YEWS}

YEW. Taxus-This is a group of evergreens that is just coming into use in landscape work. In the end it is rather doubtful if they will succeed in 
most localities out in the open, but along north foundation walls, in semi-shaded positions their value is not appreciated. The foliage is as bright and pleasing as boxwood, the needles like those of the spruce or fir, but larger. Plants may be clipped to formal shape or left to develop naturally. They are perfectly hardy in climates much colder than ours and, we believe, would do well used in shady spots where other plants fail.

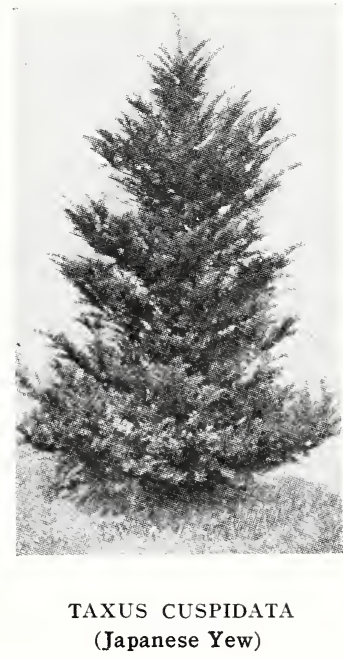

CUSPIDATA. Capitata-Of all the yews this is the only hardy, upright-growing variety in the northern states. A fast grower, standing our most severe winters and keeping its fresh color throughout the year.

12 to 15 inches................. 3.00

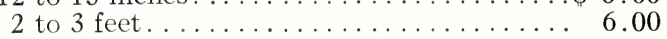

\section{REASONS WHY YOU SHOULD BUY AT HEDGE LAWN}

Because of the extensiveness of our assortment.

Because all our stock is freshly dug especially for your order.

Because we deliver by truck within a reasonable radius of our Nurseries.

Because careful packing is a feature of our service to more distant points.

Because no charge for packing is made.

Because we have a prestige of many years of dependable, satisfactory service to our customers.

Because individual digging is practiced at our Nurseries.

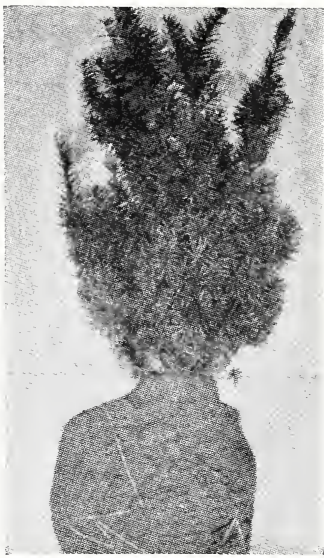

TAXUS CUSPIDATA NANA

(Dwarf Japanese Yew)

CANADENSIS. Canadian Yew. Low-spreading and bushy with small, pale green leaves, which are less numerous than the English Yew and turn to a pretty reddish tint in winter. Fruit is bright red. Very nice habit; very hardy.

15 to 18 inches................... \$ 3.50

NANA. Brevifolia-Really an excellent yew with fine, spreading branches and rich, deep green, short leaves. Highly recommended.

12 to 15 inches. . . . . . . . . . . . . . . . . . \$ 3.50

15 to 18 inches...................... 6.00

18 to 24 inches......................... 8.00

TAXUS BACCATA - English Yew. Bushy; dark, glossy foliage, rather leathery and about three-quarters of an inch in length. The berry-like fruit is intense scarlet and stands erect. Tree attains great age.

14 to 30 inches...................\$ 6.00

\section{BABY EVERGREENS}

We supply the following evergreens to those desiring a planting of the best varieties, and to those who want quality and do not mind waiting until they grow large.

EACH DOR.

Oriental Arbor Vitae, 8 to 12 inches. $\$ 1.00 \$ 10.50$

American Arbor Vitae, 8 to 12 inches $1.00 \quad 10.50$

Douglas Fir, 8 to 12 inches........ $1.00 \quad 10.50$

Concolor Fir, 8 to 12 inches........ $1.00 \quad 10.50$

Norway Spruce, 12 to 15 inches. . . 1.00, 10.50

White Spruce, 8 to 12 inches...... $1.00 \quad 10.50$

Colorado Spruce, 8 to 12 inches..... $1.00 \quad 10.50$

Deodara Cedar, 8 to 12 inches...... $1.00 \quad 10.50$

The above represent excellent values and are well worth your consideration. 


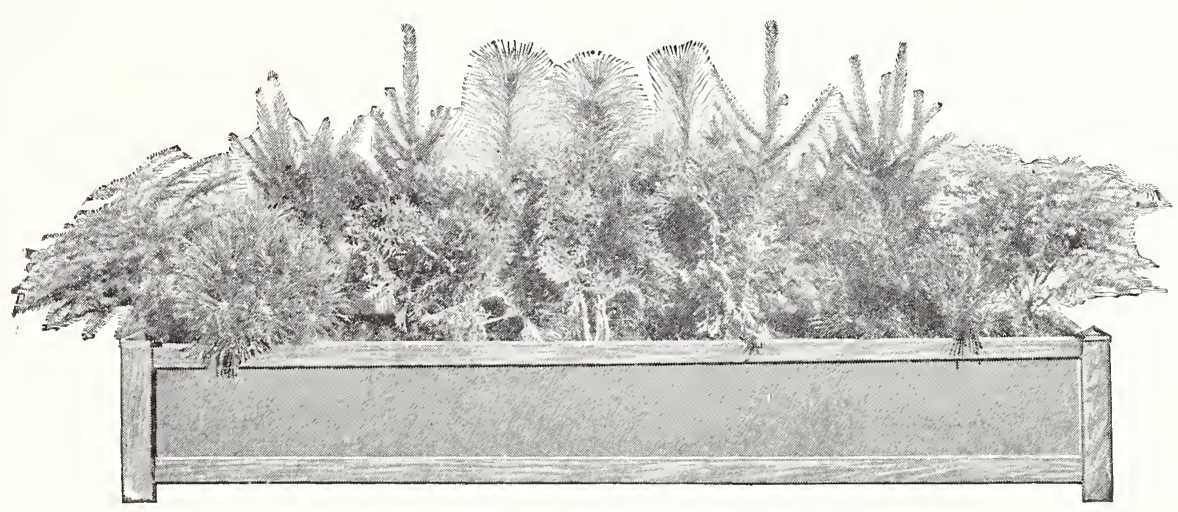

WE SPECIALIZE ON SMALL EVERGREENS FOR WINDOW BOXES

\section{BROAD-LEAVED EVERGREENS}

ACUBA JAPONICA LATIMACULATA. Golddust Plant. A shrub with glossy evergreen leaves, beautifully spotted with yellow.

12 to 15 inches

\section{THE EVERGREEN AZALEAS}

A family of Dwarf Evergreen Shrubs unique in the abundance and brilliancy of their blossoms, which occur in May. They are useful in border plantings in front of Rhododendrons and in groups and masses by themselves.

AZALEA AMOENA-Dwarf and bushy, with small green leaves, a coppery hue in winter. Always attractive, but doubly so in April or May, when clothed in a mass of dark pink or magenta flowers. Easy to transplant and maintain.

8 to 10 inches.................\$2 2.00

AZALEA, HINODEGIRI-Vivid red flowers in spring make this plant extremely showy and desirable. Its deep green leaves turn reddish in the fall. An appealing plant to the garden lover and one deserving a place on any lawn.

Jap Azalea Hinodegiri, Red, 8-inch. . . . . . . \$2.00 Jap Azalea Hinodegiri, Red 10 to 12 inches.

MACRANTHA - Red Salmon Azalea-Evergreen. A beautiful plant, with large flowers that appear at intervals, and not at one time like the preceding. Single and double varieties.

8 to 10 inches.................\$2.00

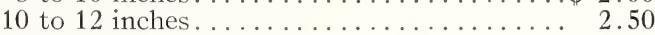

12 to 15 inches........................ 30

CALENDULACEA-Flame Azalea-Not Evergreen. The great flame Azalea of Carolina Mountains; very showy; burnt orange flowers.

18 to 24 inches.................. . 1.50

24 to 30 inches.................... 2.00

30 to 36 inches $\ldots \ldots \ldots 2.50$

3 to 4 feet..................... 3.50
MOLLIS-Chinese Azalea-Not Evergreen. Large showy flowers in shades of orange and red. May-June. Large hairy leaves. Likes sun.

8 to 10 inches............... 2.00

12 to 15 inches................ 3.00

MAHONIA Aquifolium. Holly-leaved Ashberry - A handsome, ornamental shrub, with dark, lustrous green, spiny-toothed leaves. In winter the foliage assumes a bronzy or coppery hue. Produces many yellow flowers in early spring. Berries blue or nearly black. 3 to 6 feet

18 to 24 inches...................\$ 1.50

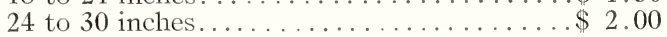
2 to 3 feet.................... 2.50

MAHONUA Japonica-Leatherleaf Holly-grape. 15 to 18 inches................\$2 . . . . . .

ILEX Crenata. Japanese Holly-A shrub with small, glossy, dark green leaves and black berries. At a distance resembles boxwood. Perfectly hardy in the South and makes a good hedge plant. 6-12 feet.

12 to 15 inches................. . . . . . . .

2 foot specimen................. 5.00

\section{ILEX, OPACA. AMERICAN HOLLY}

24 to 30 inches................ \$ 1.50 3 to 4 feet, Grafted, Guaranteed to Berry . 3.50 4 to 5 feet, Guaranteed to Berry......... 10.00 5 to 6 feet, Guaranteed to Berry......... 15.00

NANDINA Domestica-An evergreen Japanese shrub which grows well in either sun or shade and is not particular as to soil conditions if the drainage is good. The white flowers are produced in panicles and are followed by red berries. The new foliage is tinted with pink and in winter becomes a beautiful red color from the effects of cold. When old, the plants will reach a height of 6 to 8 feet.

12 to 15 inches................\$ 1.50

15 to 18 inches................... 2.00

2 to 3 feet.................... 3.50 


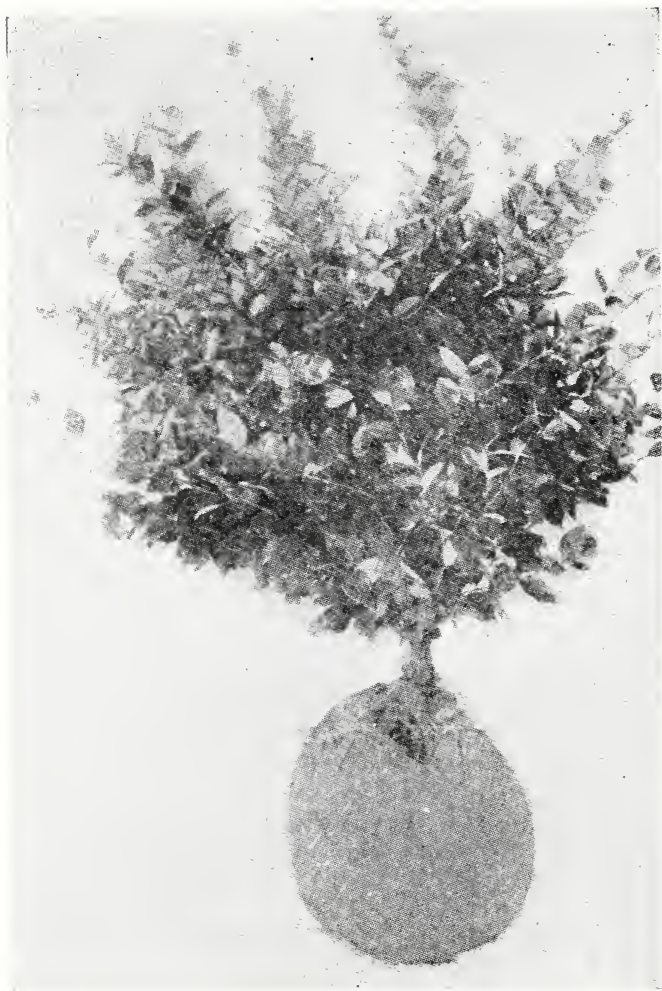

LIGRUSTRUM LUCIDIUM

\section{LIGRUSTRUM Lucidium}

15 to 18 inches.

$\$ 1.50$

2.00

24 to 30 inches.

3.50

PHILLYREA. Decora P. Vilmoriniana-Lanceleaf Phillyrea. Ornamental, woody shrub with spreading branches; grows 10 feet high.

18 to 24 inches. . . . . . . . . . . . . . 1.50

24 to 30 inches.................. 2.00

\section{RHODODENDRONS}

Handsome, large-leaved, hardy evergreen shrubs that make effective foundation planting and frontline specimens for large-growing evergreen masses. They are the most imposing and attractive of all shrubs in foliage and when in bloom the most gorgeous. No other flower is so rich in bloom and color as the Rhododendron. No planting is complete without them for they are attractive the year round and form a very pleasing mass of dark green color in the winter landscape.

R. Carolinianum-A new American species. Clear pink. Absolutely hardy. This is one of our finest introductions and fills a long-felt want for a hardy dwarf Rhododendron, with flowers free from any hint of magenta. It was described and named by Alfred Rehder, of the Arnold Arboretum. It is the smallest Alleghanian species, attaining a height of six to eight feet in cultivation. The thick-set leaves are dark green, usually blunt and narrow. Much smaller than either Maximum or Catawbiense. Flower clusters appear in greatest profusion in
June, covering the plant with a rose-colored mantle. Stands exposure unusually well and is invaluable as a single specimen or for massing.

18 inches.................. 2.00

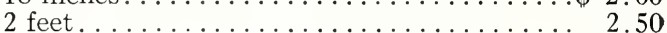

Heavy clump in bud............ 3.50

R. Catawbiense-Of the Carolina mountains. The hardiest of all the Rhododendrons. It was this magnificent Rhododendron that, over a hundred years ago, was introduced into Europe-supplying, together with R. maximum, color and hardy blood to the cultivated "hybrids." Considering the extreme hardiness, color of flower, compact growth, and remarkable texture of foliage, which is a deep, shining green, and far superior to the better-known $\mathrm{R}$. maximum, we can recommend the true native Catawbiense as the finest for general use, withstanding exposure and extremes of temperature where other Rhododendrons fail. Unlike R. maximum, it is a very free bloomer, with foliage of a dark, rich, lasting green, which never rusts. The trusses of flowers are a bright red-purple.

18 to 24 inches..................... 1.50

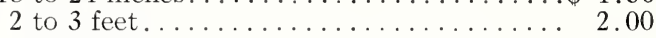

3 to 4 feet............................ 3.50

R. Maximum. Great Laurel-A well known native of our mountain regions, with great white or rose-pink clusters of flowers in June and July, just after the hybrid varieties have ceased blooming.

18 to 24 inches.................\$ 1.50

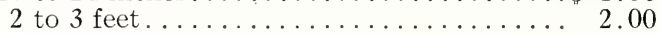

3 to 4 feet.................... 2.50

KALMIA, Latifolia. Mountain Laurel-One of the most beautiful of our Broadleaf Evergreen Shrubs of surpassing beauty when in bloom. Pink.

18 to 24 inches................... 1.50

24 to 30 inches. . . . . . . . . . . . . . 2.00

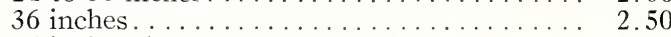

36 inches, heavy clump........... 3.50

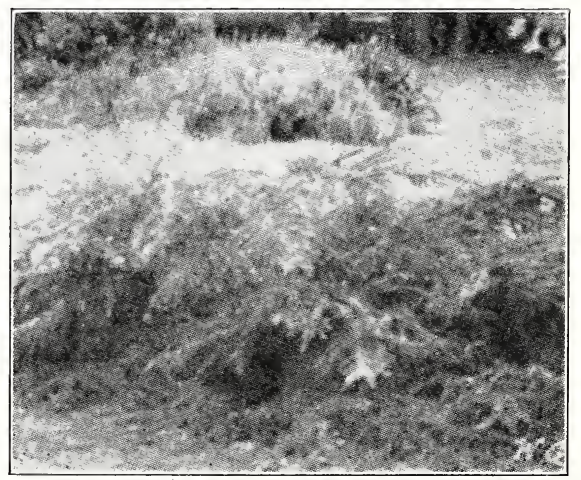

COTONEASTER HORIZONTALIS

C O T O N E A S T R Horizontalis. Prostrate Cotoneaster-A dwarf shrub with horizontal branches and small, dark green leaves. Flowers pinkish; conspicuous bright red fruit. Fine as a border plant.

2 feet....................\$2 2.00

C O T O N E A S T E R Divaricata. Spreading Cotoneaster-Spreading habit. Crimson autumn leaves; scarlet berries.

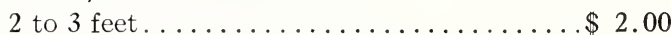


COTONEASTER Foveolata. (S)-Spreading nature. Black fruit. Autumn foliage orange and scarlet.

2 to 3 feet. .

COTONEASTER Nitens. (D)-Spreading habit. Bright red fruit in autumn.

3 feet.................\$2 2.00

\section{FIRETHORN (Pyracantha)}

Sometimes called Crataegus and Evergreen Hawthorn. A family of plants of the greatest beauty in masses against foundations, along borders, etc.; graceful branches, brilliant winter berries. The berries cling on till spring, when attractive white flowers take their place, so that the plant always has some beauty in addition to its green foliage.

\section{ANGUSTIFOLIA (Pyracantha Angustifolia)-} 8-foot growth, spreading; somewhat spiny; leaves long and narrow; berries very abundant, orangeyellow, developing very late and holding it throughout the winter.

18 inches.

$\$ 1.50$

2 to 3 feet

2.50

LALAND (Pyracantha Lalandii)-Sometimes called "Burning Bush." An evergreen shrub of spreading habit; foliage a rich, dark, glossy green; clusters of white flowers in the spring are followed by a wealth of orange-colored berries, which remain on the plant all winter.

18 inches.

2 to 3 feet

$\$ 1.50$

2.50

YONNANESE (Pyracantha Yunnanensis)-A variety of Pyracantha crenuiata; but a more vigorous grower with larger leaves. In the fall and winter there is nothing more striking than a specimen of this plant with its glossy green foliage and red berries.

18 inches. ...................\$2 2.00

2 to 3 feet

2.50

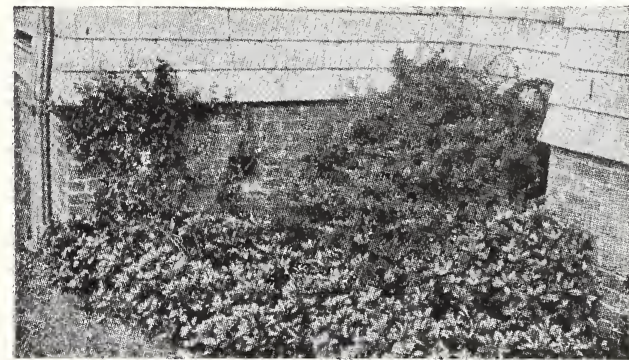

JAPANESE SPURGE AS A BORDER BARBERRY IN CORNER

PACHYSANDRA (Japanese Spurge). Terminalis-A trailing plant 6 to 8 inches high, forming broad mats of bright glossy green foliage. A ground cover which will grow in all shady situations and the only plant which will thrive under pine trees. Some of its main uses are: Under all evergreen plantings, under all shrub plantings, for areaway copings, for loggia and enclosed porch uses, for shrub and flower bed borders, for bordering walks and drives, for steep terraces in sun or shade, for city yards it is ideal, for dense shade under any kind of trees.

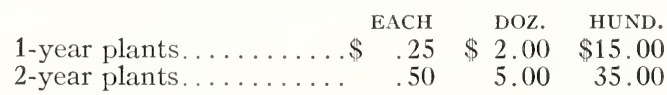

EUONYMUS Japonicus. Evergreen Euonymus - Handsome, large shrubs with glossy green leaves, holding their color all winter. Very hardy. Red berries.

18 to 24 inches.................. 1.50

2 feet....................... 2.00

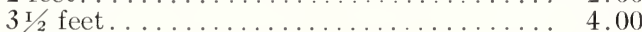

E. Japonicus Alba Variegatus. Silver Variegated Euonymus.

18 to 24 inches.... . . . . . . . . . . . . . . . \$ 2.00

2 to 3 feet..........................

E. Japonicus Aurea-Variegatus. Golden variegated Euonymus.

18 to 24 inches..................... \$ 2.00

2 to 3 feet.................... 2.50

EUONYMUS Carrierei (Glossy Wintercreeper). 18 to 24 inches.................. 1.50

2 to 3 feet..................... 2.50

E U O N Y M U S Radicans Argento-Marginatus (Silveredge Wintercreeper).

1 to $1 \mathrm{r} / 2$ feet...................\$ 1.50

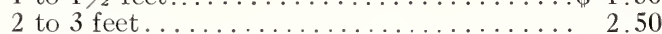

MAGNOLIA Grandifloria-Common evergreen Magnolia of the South, with large, handsome white blooms which, combined with its large, glossy green leaves, remaining on throughout the whole year, make this the greatest of all the southern ornamental trees. 30-40 feet. June 5th to July 10 th. Magnolia Grandifloria, 2 to 3 feet........\$2.00 Magnolia Grandifloria, 3 to 4 feet........ 3.50 Magnolia Grandifloria, 4 to 6 feet......... 5.00

\section{CAMELLIA (Camellia Japonica)}

The flowers are showy and wax-like, very much admired in the winter. This plant is somewhat rare, as it has been added to our lists within the last few years.

15 to 18 inches

$\$ 2.50$

HONEYSUCKLE (Lonicera) Nitida (Miniature Privet-leaved Honeysuckle). Dwarf. Almost evergreen. Can be sheared for formal specimens.

8 to 10 inches................... .75

10 to 12 inches................ 1.00

\section{DAPHNE-GARLAND FLOWER ROSE DAPHNE}

A low, spreading evergreen plant that is excellent for the foreground of evergreen beds and for rockeries. Small, tubular pink flowers of intense fragrance are borne in clusters and adorn the plant in May and intermittently all summer. A choice, comparatively uncommon plant of rare merit.

Daphne does best in a light, well-drained soil, in a sunny, protected location.

6 to 8 inches.................... .\$ 1.00

8 to 12 inches spread............... 1.50 
The winter aspect of home grounds may be greatly enhanced by a planting here and there of some of the luxuriant shrubs listed in this department. Properly grouped in beds and borders or as foundation plantings, their rich, lustrous green foliage adds color and charm to the whole planting scheme. The flowers and berries that appear in their respective seasons make these shrubs stand out strongly as year-round ornamentals. A cool, moist soil, with a porous substratum, and a northern exposure, is the preferred location with most members of the group. We ship all these Evergreen Shrubs with a ball of earth, wrapped in burlap. They will bloom the first season.

VIBURNUM RHYTIDOPHYLLUM. Leatherleaf Viburnum-Medium height; evergreen foliage, long, leathery, dark green; flowers, yellowish white; fruit, red to black.
18 to 24 inches
$\$ 2.50$

\section{LAUROCERASUS ENGLISH LAUREL}

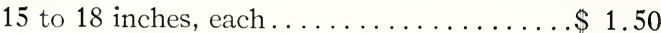

18 to 24 inches.................. 2.50

ELÆAGNUS Pungens-A spreading evergreen shrub reaching a height of 6 feet; leaves dark green above, silvery beneath. Delights in a bright, sunny location and is adapted to a wide range of conditions. 18 to 24 inches. . . . . . . . . . . . . . . . \$ 2.00

JASMINUM Floridum-A hardy shrub with glossy, dark green foliage and golden-yellow starshaped flowers a half inch in diameter, opening in spring and summer. A very desirable and valuable species.

18 to 24 inches, each . . . . . . . . . . . .\$ 1.50

\section{BOXWOODS}

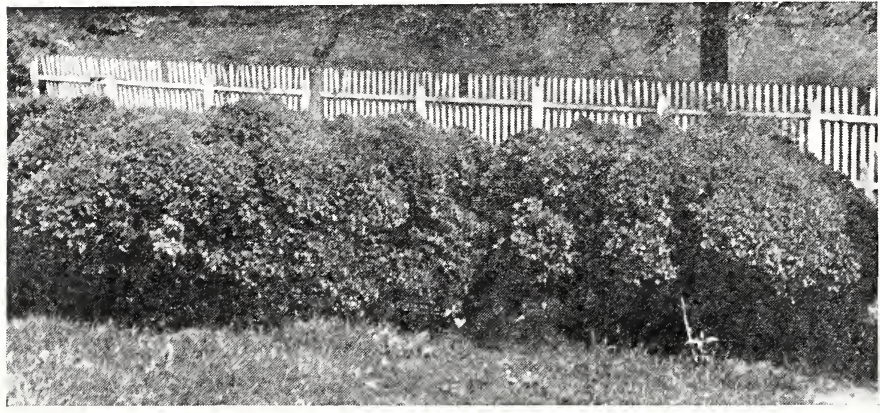

Whether your problem is to beautify a small plot in a congested city district, to produce a harmonious landscape setting for the suburban home or country estate, you will find our landscape department prepared to give you the exact information you need.

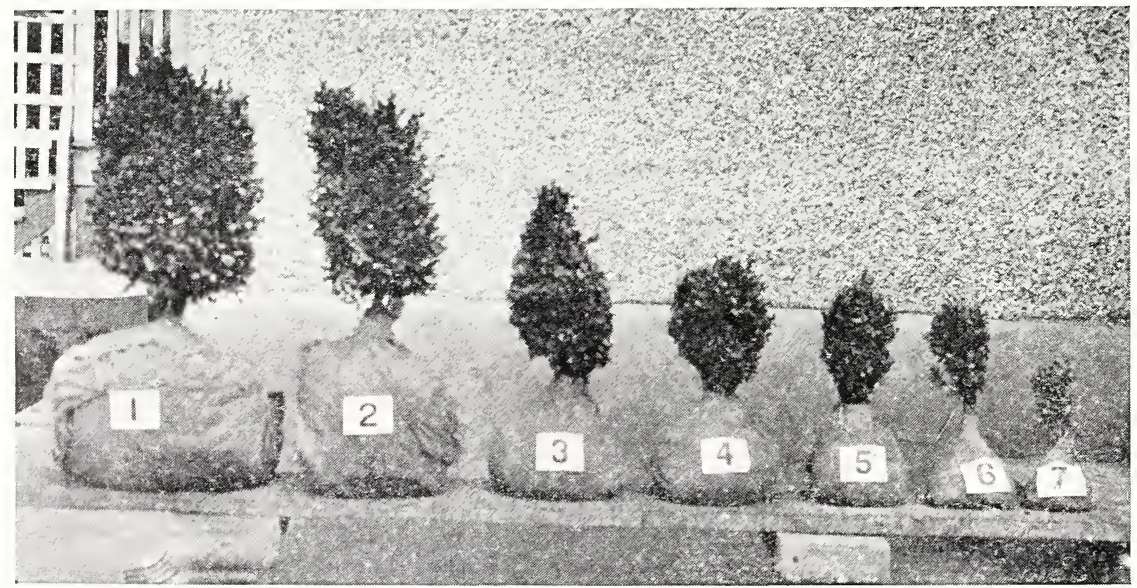

OUR BOXWOOD IS PROPAGATED FROM CUTTINGS MADE UP FROM SELECT SPECIMEN PLANTS GROWING ON GROUNDS OF OLD SOUTHERN VIRGINIA ESTATES. OUR STOCK IS LARGE AT ALL TIMES. WE SPECIALIZE ON BOXWOOD AND CAN FURNISH MOST ANY SIZE AND SHAPE DESIRED 

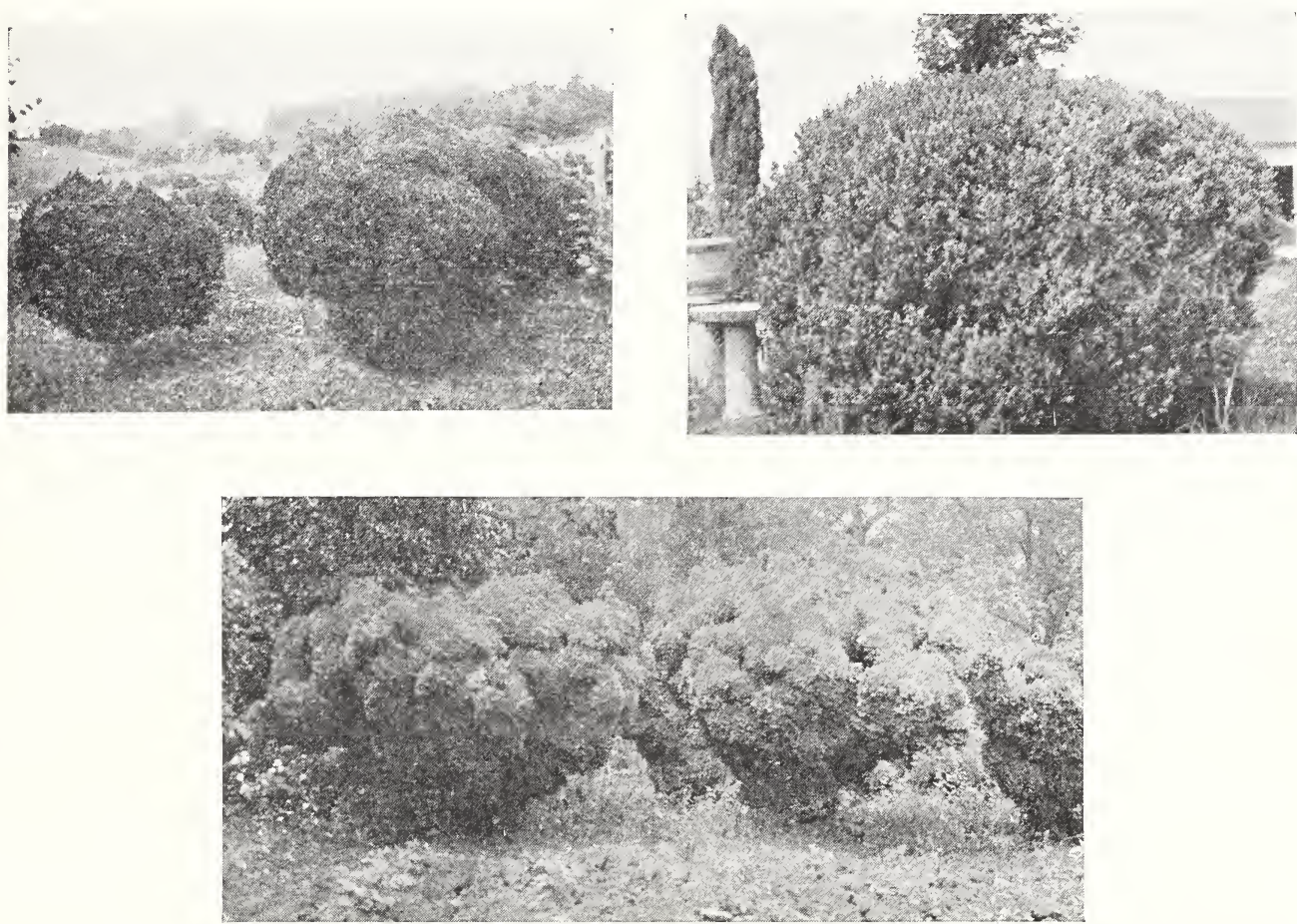

\section{OLD ENGLISH BOX}

(Suffruticosa)

We have many fine specimens, in sizes from three to ten feet. Some unusual shapcs. Some very old living antiques. Dark, rich green color, mountain grown, dug with heavy ball of clay, securely wircd to platforms for shipping.

Above will run about as follows: 6-foot plants will be six feet wide, four to five feet tall. Descriptive list on request.

\section{DWARF EDGING (Suffruticosa)}

18-inch Heavy, Extra Fancy, 91/2-inch Spread. . .

15-inch Heavy, Extra Fancy, 7 1/2-inch Spread.

Twenty-three hundred only of above to offer

$\begin{array}{rrrr} & \text { Each } & \text { Doz. } & \text { Hund } \\ 12 \text {-inch Heavy .......... } \$ 1.25 & \$ 12.00 & \$ 85.00 \\ \text { 10-inch Heavy........... } & 1.00 & 10.50 & 75.00 \\ \text { 6-7-inch Clipped......... } & .30 & 3.50 & 25.00 \\ \text { 5-inch Light Edging...... } & & 1.00 & 7.00\end{array}$

\section{SEMPERVIRENS}

(Bush Box)

42-inch Pyramid, Nursery Grown... . .

36-inch Pyramid, Nursery Grown.......

Each

$\$ 15.00$

8.00

30-inch Pyramid, Nursery Grown......... 6.00

24-inch Pyramid, Nursery Grown......... 4.50

18-inch Pyramid, Nursery Grown........ 3.00

Above sheared.

Each Doz. Hund. 24-inch Clipped. . . . . . . \$2.50\$27.50

18-inch Clipped .......... 2.00 $20.00 \$ 175.00$

15-inch Clipped . . . . . . . $1.50 \quad 15.00 \quad 100.00$

Standards-28-inch stem, 15-inch top, $\$ 8.00$ each; $\$ 15.00$ pair.

\section{TRUE TREE BOX}

Each Doz. Hund. 24 to 30-inch Heavy Clipped.\$2.00 \$20.00\$150.00

\section{YEAR-ROUND PLANTING}

Year-round planting distributes the load and relieves the stress of spring-time in the garden, when everything demands planting the same day. In spring all thoughts turn gardenward.

Many persons have the impression that all planting must be done in fall or in early spring. They think that plants become dormant by the calendar. Examination of a row of the same variety of evergreen would show some plants taking a rest even in what is generally termed the growing season. Plants that are dormant can be safely transplanted regardless of the time of year. We ship only dormant stock, summer or winter. Even deciduous plants, balled, can be safely set out in any month.

So, if the new house is not finished until late spring or summer, you can get most fun out of planting while you are of a mind to do it and have the most time. Play safe, use balled and burlapped plants and plenty of water.

Write us about your plans, enclosing a little sketch of your house and tell us approximately what you can afford to spend-we will gladly offer suggestions for a garden within the amount of money you have available. 


\section{DECIDUOUS ORNAMENTAL TREES}

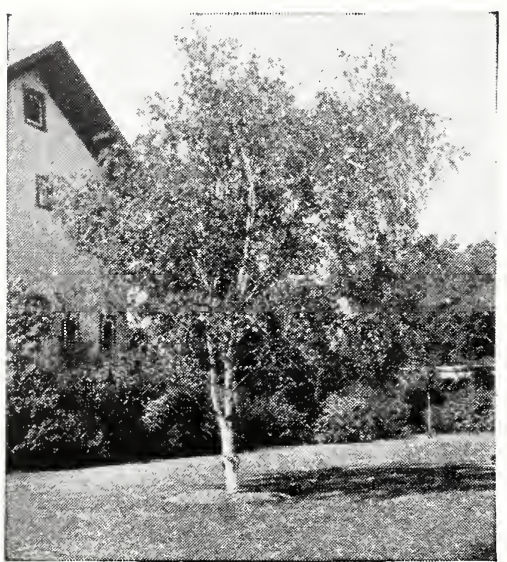

EUROPEAN WHITE WEEPING BIRCH

Volumes could be written of trees, of their value and of their beauty. They are the oldest living things. To us they have been a heritage from preceding generations and common to all mankind, we have an inborn love for them. They bring you natural beauty wherever used, whether it be on lawn, pasture, avenue or park. For shelter or shade, for fruit or blossom, for framing natural pictures, screening objectionable views, for backgrounds or seclusion they are indispensible.

Might we suggest a careful selection of what you plant? They all have some faults if not properly used. Some trees are rapid and some of slower growth. Plant for permanency the hardwood types. They grow a little slower but when you think of their longevity, beauty of form and foliage you will feel that you have made the better choice. If quick effect is wanted, interplant with the rapidgrowing varieties which can be removed when necessary. Plant them liberally and in groups for they love companionship.

\section{Planting Suggestions}

Plan to plant permanent trees thirty feet apart and those not so robust at twenty feet. Where quick-growing trees are interplanted, fifteen to twenty-five feet is suggested.

Be very sure to prune all shade trees at time of planting. This should consist of shortening the side branches, taking off, generally, the last season's growth or more. We prefer not to dehorn the tops but rather shorten the central leader in proportion to the pruning done on the side branches. Avoid making crotches, if possible, as trees later may break under ice or wind. We strongly recommend wrapping the bodies of all trees with some protective material, like burlap, paper, etc. Under our southern suns you are very likely to have badly scalded trees on the southwest side, near buildings or pavements, the reason being they are closely grown in the nursery row and there have the protective shading from the neighboring trees and the trunks are consequently tender. Usually after the second year you are safe in removing protection.
Mulching is very fine, too, to conserve the moisture. In exposed places it should be applied only in the spring on newly set large trees as it keeps the ground from freezing and the wind and weather sway the bodies, making air pockets about the roots. On small trees apply at any time.

In watering on the surface remember to give copiously as shade trees are planted much deeper than the other plants you are usually accustomed to watering. Tilling is especially fine because in this way you get the moisture down ten or twelve inches where the active root system can quickly take it up.

ASH, American. Fraxinus americana-A stately native tree with straight, clean growth, foliage light green. Dependable and very satisfactory as it grows rapidly, being a forest tree valuable for timber.

6 to 8 feet................. 1.50

8 to 10 feet...................... 2.50

BIRCH, European White. Betula alba-Tree of moderately quick growth, bark almost white, erect growing with terminal branches slightly drooping. Native of moist places but will do well when planted on dry ground. As a specimen tree and especially contrasted with evergreens it makes a valuable tree for the lawn.

European White Birch, 4 to 6 feet.......\$3.00

European White Birch, 8 to 10 feet...... 4.00

BIRCH, Weeping, White. B. Pendula gracilisThis tree is one of the most conspicuous trees grown. With its white bark, deeply cut leaves and long, pendant branches it presents a picturesque effect planted either as a specimen or otherwise. It should be pruned severely when planted and once established will prove of great merit.

European Weeping White Birch, 5 to 6 feet. .\$ 4.00

BIRCH, River. B. nigra-This is a native tree with darker bark but in foliage and general characteristics resembles the other birches.

6 to 8 feet

$\$ 2.50$

BUTTERNUT or White Walnut. Juglans cinera -This native tree is perhaps the most precocious of the nut-bearing trees. In growth it is rapid, making a round-headed tree. If you want nuts quickly, plant Butternuts.

6 to 8 feet.................... 2.00

8 to 10 feet................... 3.50

\section{PRICE REDUCTION NOTICE}

Substantial reductions from previous prices prevail.

You can now enjoy Hedge Lawn quality and service on even more profitable terms than ever.

And remember this-no extra charge for delivery, within fifty miles of Roanoke.

Visit us and see our stock. 


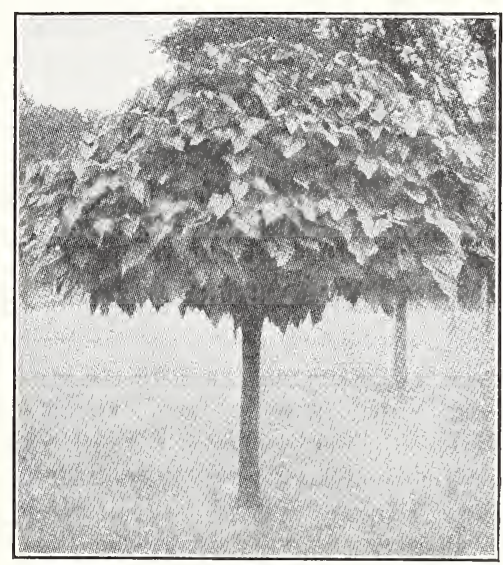

CATALPA BUNGEI

CATALPA, Umbrella. C. bungei-This tree has become popular because of its straight stems and symmetrical roundish heads which resemble an umbrella. The tops are dwarf and while they do not grow very rapidly their wide leaves give them the appearance of much larger trees. The foliage is very pleasing and the effect obtained when planted in pairs along walks, drives or entrances is greatly admired.

Catalpa Bungei, 5 to 8 feet.

$\$ 2.00$

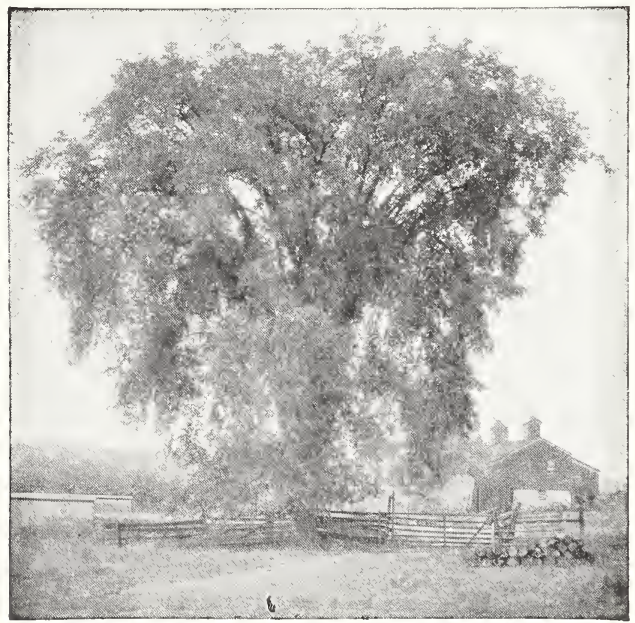

AMERICAN ELM

DOGWOOD. White. Cornus florida-A native tree well known to everyone. There is hardly a woody plant that grows that is quite as useful as our native Dogwood. Its blossoms are conspicuous, coming early in the spring, the foliage is attractive all summer and in the fall colors beautifully with red berries that hang on most of the winter. It is beautiful at all seasons of the year. It can be used as a specimen or in groups, as a background for shrub borders and when planted in contrast with bright flowering plants like Redbud it is especially showy.

White Dogwood, 3 to 4 feet..........\$ 1.00 White Dogwood, 5 to 6 feet................... 2.00

White Dogwood, 7 to 8 feet.......... 2.50
DOGWOOD. Pink. C. florida rubra-This is a colored form of the above native sort, resembling it very closely in habit of growth, period of bloom and general behavior. Conspicuous in the early spring with bright deep rose blossoms.

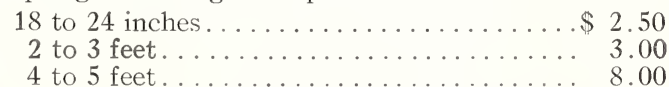

ELM. American. Ulumus americana-A tree of unusual vigor, a native too well known to describe. It is rapid of growth, with its long, spreading and pendant branches forming giant arches over roads and streets or as a lawn tree is quick to make a marked effect. The wood is tough, the leaves are moderate in size and makes a permanent tree for shade. The beetle that defoliates the European Elms usually avoids these.

American Elm, 6 to 8 feet..........\$ 1.50 American Elm, 8 to 10 feet................ 2.00 American Elm, 10 to 12 feet.......... 3.50

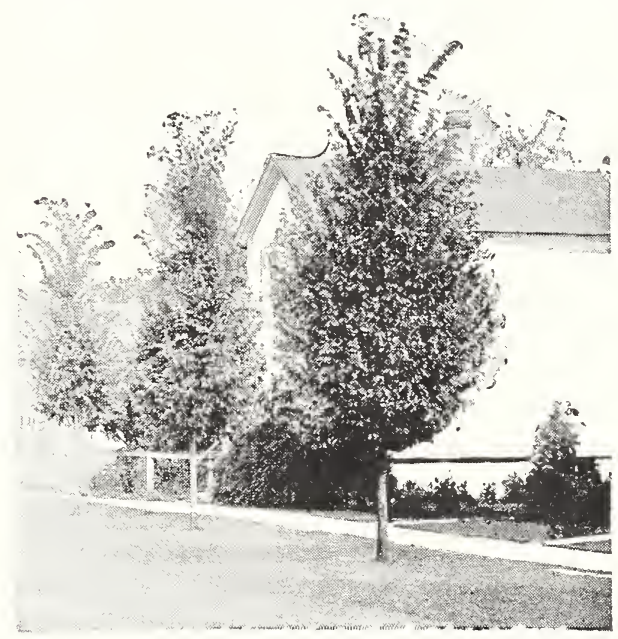

CHINESE ELM

Ulmus Pumila, Chinese Elm-New. Very fast growing variety.

4 to 5 feet.................... 1.50

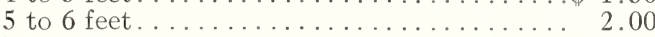

7 to 8 feet.................... 2.50

HORSE CHESTNUT, European. Aesculus hippocastanum-A tree of slow growth, yet very attractive in its roundish form with large leaves that are conspicuous in early summer. It is especially valued for the long panicles of flowers, white and tinged with red.

Horse Chestnut, 6 to 8 feet.

$\$ \$ 2.50$

Horse Chestnut, Red, 3 to 4 feet

10.00

\section{PUT HEDGE LAWN ON YOUR LIST FOR A} VISIT THIS SEASON

You are cordially invited to visit us.

Come and see for yourself the quality of our plants and our facilities for handling your order.

Few Nurseries are as well equipped to serve you to your complete satisfaction as we are.

Try us this season and let us prove it. 


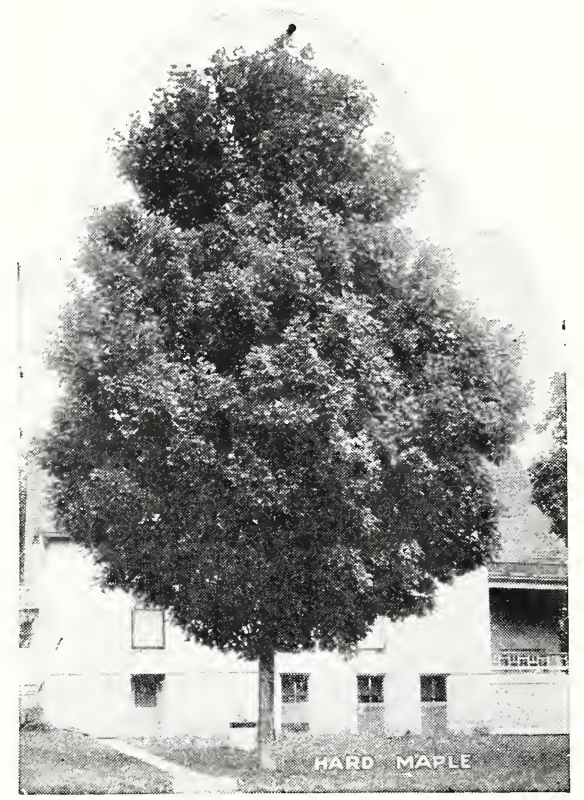

NORWAY MAPLE

GUM, Sweet. Liquidambar sytaciflua-Another native tree not appreciated. It is not of rapid growth nor especially easy to transplant, but the glossy foliage in summer, the brilliant color in the fall and the unusual appearance in the winter of the young branches with their corky bark are considerations that make it especially valuable.

Sweet Gum, 6 to 8 feet..............\$ 2.00

Sweet Gum, 8 to 10 feet.

KENTUCKY COFFEE. Gymnocladus dioicaNative to Kentucky. Very blunt, sturdy branches, inconspicuous buds developing into frond-shaped leaves, giving the tree a more tropical appearance than any other native. Flowers inconspicuous but superbly fragrant.

Kentucky Coffee, 6 to 8 feet..........\$2.00

Kentucky Coffee, 8 to 10 feet.......... 3.00

MAIDEN HAIR. Ginkgo biloba-A conifer, but deciduous. It is allied to the Pine family. On close examination of the leaves one will note the aborted pine needles bound together into a solid leaf. It is of Asiatic origin and carries with it the indescribable oriental appearance in the shape and position of its branches, leaves, character of growth and color of bark. Perfectly hardy; here and in the East largely used for avenue trees.

Maiden Hair Tree, 8 to 10 feet. . . . . . . .\$3.50

\section{MIMOSA TREE}

A low-growing tree with spreading branches, forming a flat-topped head. Foliage finely divided; pinkish flowers borne in terminal clusters.

4 to 6 feet.

$\$ 1.50$

6 to 8 feet.
LINDEN, American or Basswood. Tilia americana-This native tree is very attractive and will grow rapidly when planted in low ground. The leaves are distinctly larger than other varieties, branches pendulous in habit of growth and makes an excellent shade tree under favorable conditions. American Linden, 6 to 8 feet. . . . . . . .\$ 1.50 American Linden, 8 to 10 feet......... 2.50 American Linden, 10 to 12 feet........... 3.50

LINDEN, European. T. vulgaris-A very compact, pyramidal tree of dark green foliage, easy to transplant and very satisfactory for avenue or lawn planting. Leaves are large, heart-shaped; the branches are smooth and tough and when the tree blooms, which it does profusely, the fragrance is noticeable for a considerable distance.

European Linden, 6 to 8 feet..........\$2.50 European Linden, 8 to 10 feet............ 3.50

MAPLE, Norway. Acer platanoides-A tree resembling the Sugar Maple in character, but of darker and larger foliage, round and spreading in habit of growth. It is really the European Hard Maple and retains this character here. For lawn, as specimens or shade, to plant on streets beneath wires or for spreading over sidewalks, parks, cemeteries or for avenue or arching over roadways this tree is highly recommended. Sometimes the trunks are inclined to be slightly crooked when young, but it is well known that they grow out of this unsightliness in a few years when planted in the open.

Norway Maple, 5 to 6 feet.............\$2.00

Norway Maple, 8 to 10 feet.......... 2.50 Norway Maple, $21 / 2$ to 3 inches caliper.

$\$ 8.00$ to 15.00

M A P L E, Sugar. Acer saccharum-Known everywhere and is so popular that it is difficult to keep a well-grown supply on hand. Tree grows to be of great size, foliage of good color and in the fall turns indescribably to all tints imaginable. Being of erect, conical growth, perfectly hardy and wood of such texture that it will survive any abnormal condition of the weather and its adaptability to all types of soils makes it a variety justly popular. Native grown, it proves valuable for the timber for hard wood finishing and also "tapped" for maple sugar.

Sugar Maple, 5 to 6 feet. . . . . . . . . . .\$ 1.50

Sugar Maple, 8 to 10 feet............ 2.50 Sugar Maple, 2 1 $/ 2$ to 3 inches caliper.

$\$ 6.00$ to 10.00

MAPLE, Silver or Water. Acer dasycarpumBecause of its quick growth, good foliage and ease to transplant, this tree is in great demand. The tree blooms very early in the spring, leaves appear promptly, being light green in color but silvery beneath, and these remain until late fall. For planting as temporary trees-that is, alternating between the hardwooded and slower growers, as Oaks, Elms, Sugar Maples, Gum, etc., this variety is highly recommended.

Silver Maple, 6 to 8 feet.............\$1.00

Silver Maple, 8 to 10 feet............ 1.25

We have a limited quantity of large shade trees. We will be glad to quote on request. 
M A P L E, Schwedler's. Acer Platanoides schwedleri-A tree resembling the Norway Maple in every respect except in early spring the foliage is a bright purple, changing from bronze to dull green. In the fall it turns bronze before defoliating. 8 to 10 feet

$\$ 4.00$

PALMATUM ATROPURPUREUM. Bloodleaved Japanese Maple-In the spring the starshaped foliage is a dark red, turning to purplish red and retaining that color most of the season. Probably the best, and certainly the most popular, of all the Japanese Maples because of its effectiveness when placed where it has a background of green foliage. Makes a bushy specimen 10-15 feet high. Japanese Red Maple, 15-18. . . . . . . . . . . 6.00 Japanese Red Maple, 18-24............ 8.00 Japanese Red Maple, 24-30. . . . . . . . . . . 10.00

PALMATUM. Green Japanese Maple-This is the parent of all the Japanese varieties. The small green leaves are not so deeply cut as those of some varieties, but the foliage is a bright green in the spring and summer and makes a gorgeous showing in the autumn, when it assumes rich tones of yellow and scarlet. 15-20 feet.

3 feet.

$\$ 1.50$

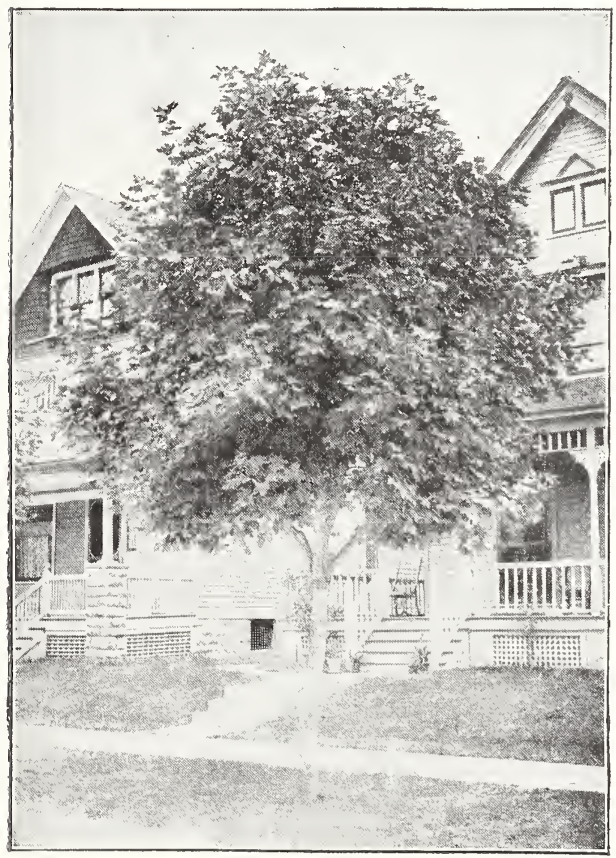

ORIENTAL PLANE

SYCAMORE, American or Plane Tree. Platanus occidentalis-A native, sometimes thought too common to plant. However, where a tree for quick effect is wanted, one clean in habit of growth, luxuriant of foliage and easy to transplant, this lesson of Nature in distributing it so liberally should be accepted. The bark is silvery or grayish in winter, the leaves hold on well and for avenue, street, lawn and paddock shade, the Sycamore can be satisfactorily used.

8 to 10 feet
PLATANUS ORIENTALIS. European Plane Tree-This rapid-growing, svmmetrical, widespreading tree is most suitable for city street planting. Attractive trunk and foliage, fine, symmetrical head. Not bothered by insect pests or smoky, dusty locations.

6 to 8 feet................... 2.00

8 to 10 feet................... 2.50

OAK, Pin. Quercus palustris-Of all the Oaks this is preferred. Perfectly symmetrical from the base branches up, foliage a shining green, leaves deeply cut and in fall of wonderous colors - a combination for beauty, symmetry and durability not found in any other tree. It is the easiest of the Oaks to transplant, more rapid of growth and in any capacity a tree may be used, whether shade, specimen, avenue, cemetery or park tree, if one is a little patient the reward is commensurate. We are very partial to it and when a hardwood tree is wanted for any location we unhesitatingly recommend Pin Oak. If you knew it as we do you would be equally enthused.

Pin Oak, 5 to 6 feet................\$ 3.00

Pin Oak, 8 to 10 feet.............. 6.00

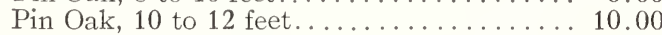

PECAN. Hickoria Pecan-There has been a great deal said about these of late but on our soil conditions they are very hard to establish and exceedingly slow of growth. They are hardly worth trying on limestone soil and unless you have more favorable conditions than in Central Virginia they will be disappointing. We have found the seedling trees to be more vigorous than the budded varieties where favorable locations are to be had. For fruit there is no comparison as the named varieties are much superior and we would advise the purchase of these if you wish to experiment with them.

5 to 6 feet.

POPLAR, Lombardy. Populus nigra italicaA tall, slender tree reaching great heights, very easy to transplant and of most rapid growth. Specimens often reach fifty feet with a spread of less than ten feet, and for this reason when tree plantings are needed for narrow places, between buildings, congested lawns, narrow avenues, this may be used with great satisfaction. Because of its great height and quick growth it is commendable for backgrounds of buildings, to add character to plantings or to offset straight or bare lines. Further, for screening unsightly views, fire protection from close buildings or wind breaks - and all for quick effect, we unhesitatingly recommend this variety. A false impression prevails that it sheds its leaves early, but this is a misapprehension, as the tree is healthy in growth and foliage.

Lombardy Poplar, 5 to 6 feet..... . . . . . . \$ . .50

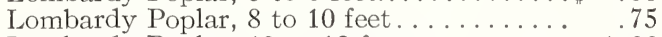

Lombardy Poplar, 10 to 12 feet.......... 1.00

Lombardy Poplar, 12 to 15 feet.......... 1.50

\section{CHINESE POPLAR}

A tall, rapid-growing, small-leaved variety. Poplar of upright, pyramidal habit and a good grower.

5 to 6 feet................... .50

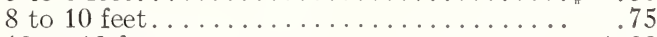

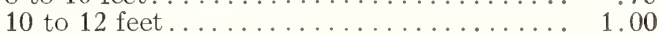


REDBUD or Judas Tree. Cercis canadensisA native of our woods, literally covered with its red or pink blossoms early in the spring before it opens its leaves. It is an early harbinger of spring, blooming in April. It is a small, shapely tree, wood very tough, and the leaves large and very green in color. It may be used in heavy mass planting of shrubs with White Flowering Dogwood or against evergreens or White Birch, making a pleasant contrast.

Redbud, 5 to 6 feet.

$\$ 1.25$

Redbud, 6 to 8 feet.

Redbud, 8 to 10 feet

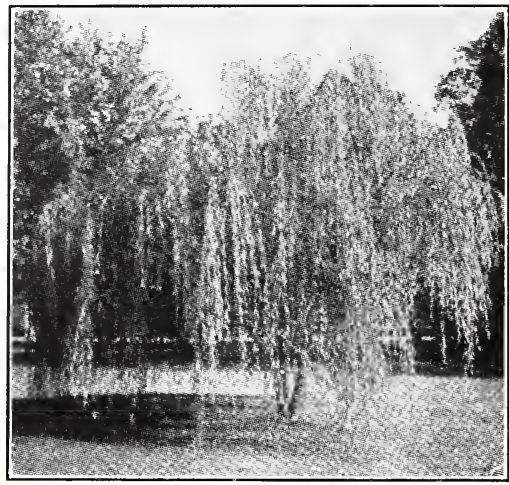

WEEPING WILLOW

WILLOW, Weeping. Salix babylonica-A tree of stately appearance with long pendant branches swaying their silvery foliage in every breeze, quick to take hold when transplanted, will give a finish to a lawn not obtained in any other tree. This, too, makes a good screen and whether planted on moist or dry ground thrives with unusual vigor.

Babylonica Weeping Willow, 5 to 6 feet. . .\$ 1.00 Babylonica Weeping Willow, 8 to 10 feet. . 1.50

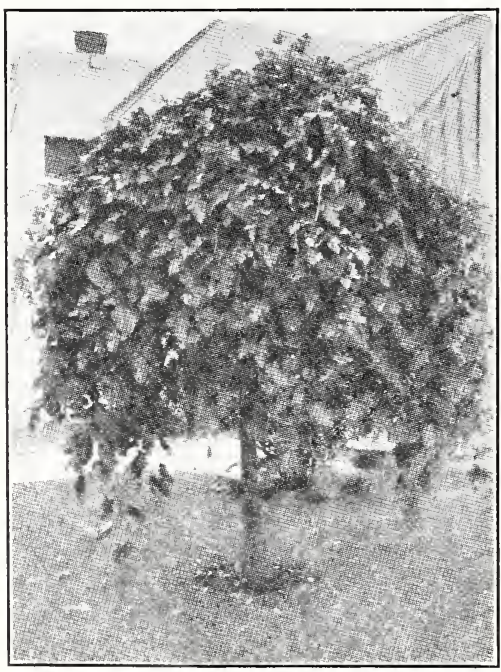

WEEPING MULBERRY

MULBERRY, Weeping. Morus alba pendulaA very old tree, immediately attractive with its long, sweeping branches that touch the ground.
It is grafted on its parent stock-Russian Mulberry-and is entirely free of all disease and bears some fruit.

Teas Weeping Mulberry, 2-year.......\$ 3.00

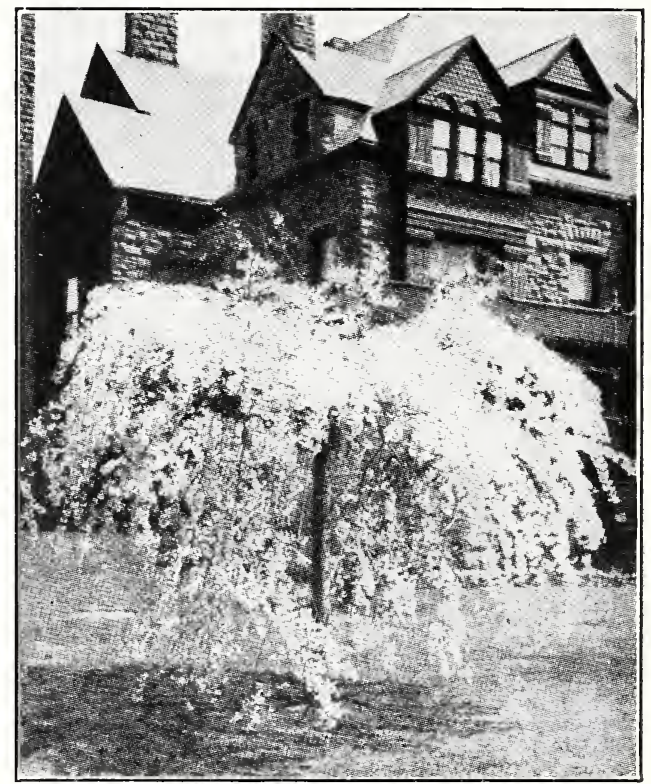

JAPAN WEEPING CHERRY-A FOUNTAIN OF ROSY BLOOM

\section{JAPANESE CHERRIES}

We offer the following list of the choicest imported varieties.

CHERRY (Prunus). Fruticosa pendula (japonica pendula)-Weeping Bush Cherry. Single pink flowers.

3 to 4 feet.

$\$ 6.00$

CHERRY, JAPANESE FLOWERING (Cerasus)

Beni-Higan-Large pink flowers.

4 to 5 feet

$\$ 2.50$

Kofugen-Double, deep pink.

4 to 5 feet.

$\$ 2.50$

Fugenzo (J. H. Veitch)-Double, pink. Late. 4 to 5 feet.

S 2.50

Kwanzan (Kanzan-Sekiuama)-Double, dark pink. Late.

4 to 5 feet.

$\$ 2.50$

MAGNOLIA, Southern. M. grandiflora-The broad, shiny leaf evergreen, giant of the forest. Immense white blossoms. Well known throughout South. Beautiful from small tree to maturity.
2 to 3 feet.
$\$ 2.00$
3 to 4 feet.
3.50
4 to 6 feet.
5.00

SAUCER MAGNOLIA. M. soulangeanaHardy, vigorous, large, glossy foliage; pink, cupshaped flowers in April. One of the best garden or specimen plants.

2 to 3 feet.

$\$ 5.00$ 


\section{DECIDUOUS FLOWERING SHRUBS}

$\mathrm{I}^{\mathrm{N}}$ diversity of form, variety of species, contrast of foliage and variation of blossom this group holds unusual interest and as a group they prove to be the finishing touches or tints of virtually all landscape plantings. With trees we have made our bolder outlines and shaded the grounds but to this group we come to soften the borders or edges of drives, walks and boundaries; to emphasize some lawn feature; to mellow rigid lines or sharp angles; to fill depressions; to screen objectionable views; to cover slopes or divide areas. From early spring, yes, even late winter, they unfold their wondrous bowers of yellow, pink, white and red flowers on backgrounds of purple, yellow, light and dark green foliage. The attractive fruits and berries often adhere after autumn has spread its brilliant colors on the foliage. Proper selection as to height and careful choosing of varieties will insure the accomplishments mentioned and provide a source of indescribable pleasure to the home owner.

\section{PLANTING SUGGESTIONS}

There is always a tendency to overplant in the attempt of immediate effect. Don't be impatient as it takes several years to grow mature plants. So, in planning your requirements, here is a general rule to apply - on real good soil the spread of a shrub usually approximates the height, in other words, a five to six-foot shrub will just about spread that much.

\section{ABOUT PLANTING}

Dig holes and plant as deeply as they stood in the nursery row. Shake the plants so the soil will sift into the roots. Some shrubs have great masses of fibrous roots that if the soil is merely thrown on top, they will surely die. Contact with every root insures growth, so work the earth carefully through these masses. In pruning take off about one-half the tops; at least a third.

The pruning after development causes confusion. "Prune when the knife is sharp," has long been a saying and no shrub was ever killed by pruning.

However, one time is no better than another and, unless otherwise necessary, you will find that the best results are obtained by light pruning immediately after the blossoms fall. Heavy pruning at any time will cause the plants to put aside their blossom-forming buds and make wood growth and you lose or lessen the next season's blossom. That is why light pruning is suggested annually or biennially. Pruning in the dormant stage is not injurious and some plants can be so much better shaped when the branches are defoliated. In all pruning do not bob off the tops and make hedges of your massed plants. This causes a new "breal"" or ugly offset giving them a two-story effect. Shorten the canes to a side branch so that it will develop all the natural pendancy or other characteristics of the plant. To remove canes, cut close to the crowns as this causes them to renew naturally from the bottoms. Now for the perpetual exceptions-all terminal blooming plants like hydrangeas, hypericum, bush roses, etc., that bloom on the "tips" of the new growth need severe pruning if large blossoms are wanted. Constantly renew this young wood by pruning in the dormant and semidormant period only.
ALTHEA. Rose of Sharon. Hibiscus SyriacusThese are tall, slender shrubs that do well under congested city conditions and other places where some of the woody plants fail to grow. The blossom period usually starts in July and extends to September. Altheas are greatly used for hedge and screen purposes. Please note they may be bought to color.

Single White-Blossoms white with pink center. 3 to 5 feet............... .50 and $\$ .75$

Double White-(Jeanne d'Arc). This is a pure white, double-flowering variety. Very attractive. 3 to 5 feet.............. .50 and $\$ .75$

Double Red-(Boule de Feu). Freest blossoming of all the doubles. Very attractive; bright in color.

Lady Stanley. White Shaded Rose-

Semi-Double, 3 to 5 feet..... $\$ .50$ and $\$ .75$

Ardens, Double Purplish Blue, 3 to 5 feet.

$\$ .50$ and $\$ .75$

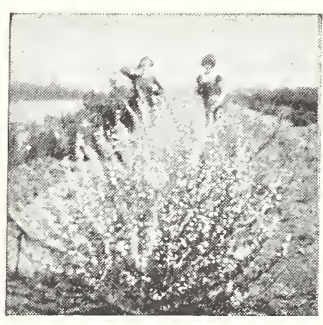

FLOWERING ALMOND
ALMOND. Pinkflowering Almond. Prunus glandulosa(F.) 3-4 feet. Rose pink. April. Very attractive shrub. The plants are usually thickly studded with double pink flowers of medium size from base to tip of branch. The plants are usually propagated on plum or peach stock as it belongs to this family and should be planted deeper than ordinarily advised for other shrubs.

Flowering Almond, Pink and White,

2 to 3 feet.

3 to 4 feet.

$\$ 1.50$

CALYCANTHUS Floridus. Sweet Shrub or Allspice-(F.) 4-5 feet. Chocolate brown. This is an old-fashioned shrub well known to everyone. It blossoms intermittently all summer and its flowers are usually very sweet scented.

Calycanthus, Sweet Shrub......\$.50 and \$.75

\section{NEW RED LEAFED JAPANESE BARBERRY}

Price, $1-$ Year Plants............... .75

Price, 2-Year Plants. . . . . . . . . . . 1.00

CORAL BERRY or Indian Currant. Symphorocarpus vulgaris - 4-5 feet. June. This is a native shrub that in many localities grows in great masses. It is very hardy and easy to establish where other things fail. Its beauty lies in the wonderful wealth of coral berries that come in late summer and usually adhere all winter.

Coral Berry, 2 to 3 feet........\$.50 and $\$ .75$

C R A N B ER R Y. Highbush Cranberry. Viburnum opulus - 8-10 feet. White. May. This plant belongs to the Snowball family and is unusually attractive because of its bright berries that attract birds in mid-summer and also for its color effect in the fall. The flowers are inconspicuous. 
This is one of the best things for natural planting but, owing to scarcity of stock, it has not been largely used...............\$.50 and $\$ .75$

CRABS, Bechtel, Flowering. Malus ioensis plena-10 feet. Pink. May. This is an unusually attractive tree in full blossom; flowers being fragrant, double, resembling a miniature rose. The foliage is very much like an ordinary apple tree but there is no plant in the catalogue that is quite as attractive as it is when in full blossom. Rather slow growing and more expensive than ordinary shrubs but well worth the space it occupies.

3 to 4 feet.

$\$ 1.50$

CRABS. Single Japanese. Malus florabunda10-15 feet. Deep rose. May. This is a single blossom borne in large clusters and inclined to be drooping. The flowers are considerably smaller than the Bechtel, but showy, because of its very deep color and mass of blossom. It has never been plentiful in the nursery trade.

3 to 4 feet.

$\$ 1.50$

Niedzwetzkyana, Redvein Crab-Early. A Russian Turkestan species, remarkable for the red color of flowers, branches, leaves and fruit. 3 feet.

Scheideckeri, Scheidecker Crab-Early. Small tree of pyramidal habit with small bright rosecolored flowers in great profusion. 3 feet.

MALUS, Crab. Arnoldiana, Arnold Crab-One of the most beautiful varieties, originating at the Arnold Arboretum. Very large rose-colored flowers, turning to white.

3 feet.

$\$ 2.00$

CRAPEMYRTLE. Lagerstroemia indicaFamiliar to everyone living in the South. It has small, very dark green shining leaves and blossoms in August and September in panicles of peculiar but attractive flowers. Can furnish pink, red and purple.

3 feet, B. \& B.

$\$ 1.00$

CALLICARPA Japonica. Japanese Beautyberry -August. Pink flowers, violet berries.

$\$ .50$ and $\$ .75$

CYDONIA Japonica. Japanese Quince-May. Scarlet..............\$.50 and $\$ .75$

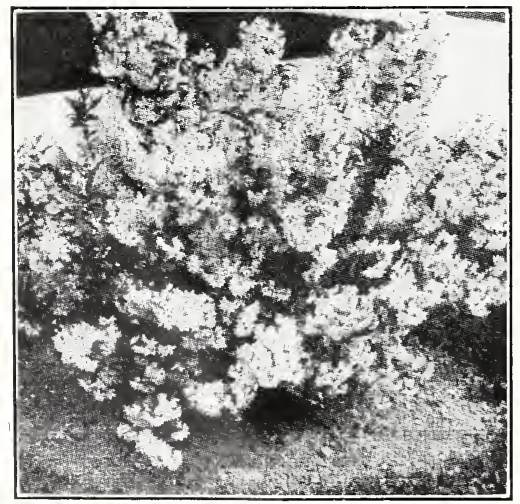

DEUTZIA GRACILIS
DEUTZIA. D. Scarba candissima or Snowflake Deutzia-6-10 feet. White. June. A Japanese shrub noted for its hardiness, fine habit of growth and profusion of attractive flowers which are borne racemes. The small flowerettes resemble double Lily of the Valley. Where quick effect and screen is wanted this is a very desirable plant.

3 to 4 feet..............\$.50 and $\$ .75$

D. Pride of Rochester. D. Scabra-(F.) 6-8 feet. Pinkish white. June. This variety is very much the same as Deutzia candissima, but is more popular on account of its color. It is very hardy, adapting itself to any type of soil and if better known would be one of the most popular shrubs planted to-day.

3 to 4 feet

$\$ .50$ and $\$ .75$

D. Gracilis. Slender Deutzia-(F.) $1 \frac{1}{2}-2 \frac{1}{2}$ feet. White. May. This is a dwarf shrub, very dense in growth, blooming profusely in small racemes on arching branches. Sometimes caught by late freezes but in protected places can be used as a low growing shrub for border planting. We have some trouble occasionally, it being troubled with leaf spot and mildew.

2 to 3 feet. . $\$ .50$ and $\$ .75$

D O G W O O D. Blood-Twig Dogwood. C. sanguinea-7-8 feet. Greenish white. June. This is a true Osier, being adapted to moist places. It is a strong grower. The stems of this variety are deep red and are very attractive in winter.

3 feet....................\$ 1.00

E L D E R. Golden American. Sambucus canadensis-8-10 feet. White. July. This is one of the best foliage plants grown under southern conditions. It holds its bright color the entire summer and is very conspicuous in a mass planting. It has the usual Elder blossom of large size and this is followed by a very attractive berry. All Elders are quick to establish themselves and do well on all types of soil.

3 to 4 feet..................\$ 1.50

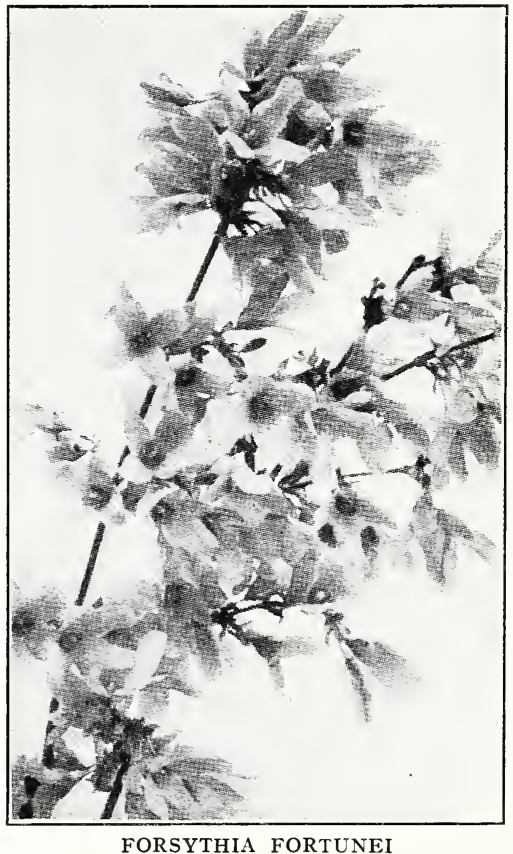

FORSYTHIA FORTUNEI 
Fortune's Golden Bell. F. Fortunei-6-8 feet. Yellow. April. A form of F. suspensa, but with more upright branches and darker.

$$
\$ .35, \$ .50 \text { and } \$ .7 .5
$$

Forsythia Suspensa or Drooping Golden Bell6-8 feet. Yellow. April. A drooping variety that makes a desirable bush when planted alone or can be made to arch trellises, etc. . $\$ .35, \$ .50$ and $\$ .75$

\section{FORSYTHIA SPECTABIL, NEW}

3 feet. . . . . . . . . . . . . . . . . . . \$ 1.00

French Hydrangea, different colors, $\$ .75$ and $\$ 1.00$

HYDRANGEA, Old-Fashioned. H. paniculata grandiflora-(Great Panicled Hydrangea.) (F.) 4-5 feet. White. August. Commonly known as Hardy Hydrangea............. $.35, \$ .50$ and $\$ .75$

HYPERICUM. St. John's Wort or Gold Flower. H., Moserianum-(F.) 1-2 feet. Yellow. July to September. This rather unique lowgrowing shrub always attracts attention. Flowers, a beautiful rich yellow, borne on slender stems, surrounded with rather roundish, leathery green leaves throughout the summer. During severe winters it often kills to the ground but next spring will come back more vigorous than before.

\section{$\$ .50$ and $\$ .75$}

HONEYSUCKLE. Fragrant Bush. L. fragrantissima-(F.) 7-10 feet. White. April. So called because of its very fragrant blossom. The foliage is very deep green and glossy. This grows well in partial shade, in adverse soil or in cities where tender plants fail. Because of its nearly evergreen habit it is being largely used for hedges. Without doubt one of the very best plants for landscape purposes grown to-day.....\$.50 and $\$ .75$

HONEYSUCKLE. Morrow's Honeysuckle. L. morrowi-8-12 feet. This is one of the best quick growing, compact and "filler" shrubs we have. The foliage is bright green, the blossoms cream colored, appearing in April. The red and coral fruits follow from June to August. In dry or moist soil, shade or sun, city or country, this variety will thrive................50 and $\$ .75$

L. Tatarica-7-9 feet. Pink. April. This is very attractive in blossom, being one of the few early pink flowering shrubs. Has bright red berries that stay on all summer..........\$.50 and $\$ .75$

\section{LILACS}

Claude Bernard-Semi-double; bright mauve lilac.

De Miribel-Single; large trusses of bluish violet flowers, very dark.

Edith Cavell-Double; bold, handsome clusters, pure white, buds suffused cream white.

Edouard Andre-Double; clear rose or nearly pink; one of the best of this color.

If shipment is wanted by parcel post, be sure to include in your remittance sufficient to cover postage charges.
Emile Gentil-Double; large imbricated flowers, bright cobalt-blue, a very rare shade.

Jean Mace-Double; very large clusters, bluish mauve, a most distinct variety, very free.

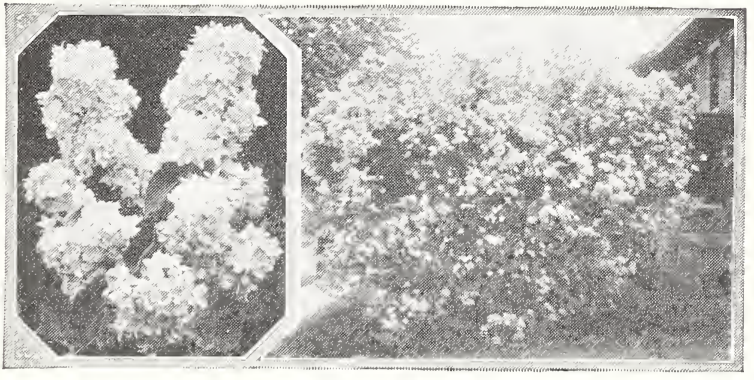

LILACS

Marechal Lannes-Semi-double; bluish violet, very large individual flowers.

Miss Ellen Willmott-Double; large clusters of imbricated, snow-white flowers of perfect form.

Montaigue-Double; pinkish mauve, very large.

President Faillieres-Double; pale lavender, very large clusters.

Vauban-Double; tender mauve.

Waldeck-Rousseau-Double; deep violet, long trusses.

The above Lilacs are the best varieties you can buy.

Price, 18 to 24 inches. . . . . . . . . . . \$ 2.50

LILAC. Common Purple. S. vulgaris-7-10 feet. This is the old-fashioned variety always so familiar in our grandmother's garden. Usually more vigorous in growth than the white variety.

Lilac, Purple, 3 feet.......\$.50, $\$ .75$ and $\$ 1.00$

Lilac, White, 3 feet...... .50, .75 and 1.00

\section{LILAC. French}

Charles X-Single; fine clusters of lilac flowers, slightly violet, very free.

24 inches....................\$ 1.50

Charles Joly-Double; dark violet purple, silvery reverse.

24 inches. . . . . . . . . . . . . . . . . \$ 1.50

President Grevy-Double; blue, one of the best in this color; fine, large trusses.

24 inches. . . . . . . . . . . . . . . . . \$ 1.50

Plan a private backyard garden.

A wild retreat for the summer

"Out-o'-Door Parties." 


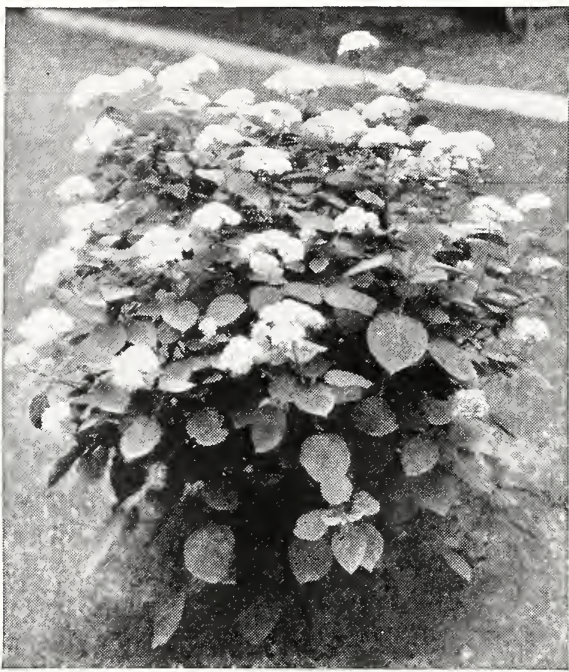

HYDRANGEA, HILLS OF SNOW

MOCK ORANGE or Syringa. Philadelphus coronarius. Sweet Mock Orange-(F.) 6-8 feet. White. June. The old-fashioned mock orange, well known to everyone because of its waxy white, fragrant flowers. It proves a specially good plant for every use, the foliage being large, oval in shape and deep green. For cut flowers it is valuable and pruning in this manner often keeps the bush confined where it is not desirable to have it grow too tall. Very valuable for background, screen or grouping.

3 to 4 feet.

$\$ .50$ and $\$ .75$

VIRGINAL, NEW, 2 to 3 feet. $\$ 1.00$

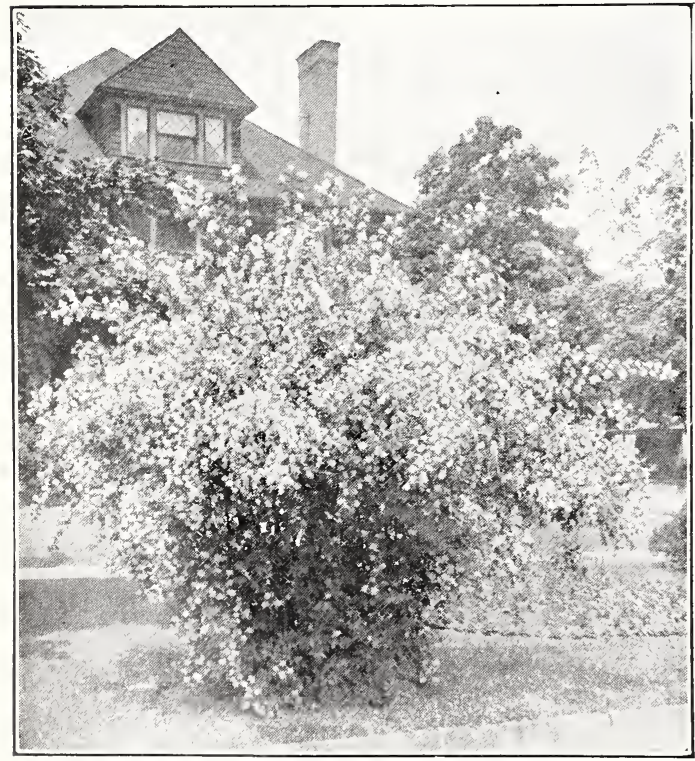

MOCK ORANGE

MOCK ORANGE. P. grandiflorus or large flowering Mock Orange-7-10 feet. White. June. This is a more vigorous grower than the preceding but lacks the fragrance. Blossoms are larger and very attractive. Where a tall plant is wan ted there is hardly anything better than this. Succeeds under all soil conditions.

3 to 4 feet.............. .50 and $\$ .75$

RHODOTYPOS or Jetbead. R. kerriodes-(F.) 4-5 feet. White. May and June. Very ornamental shrub with bright green, plaited leaves and large white flowers, one-half to one inch across. These are produced in the end of the branchlets and are followed by conspicuous shining black fruit that adheres practically all winter. A desirable shrub. 3 to 4 feet.............. .50 and $\$ .75$

SNOWBERRY. Symphoricarpos racemosus(F.) 4-5 feet. This shrub has small pinkish flowers in July, followed by white berries which remain on well into the winter. Very attractive, medium-growing shrubs.....\$.35, $\$ .50$ and $\$ .75$

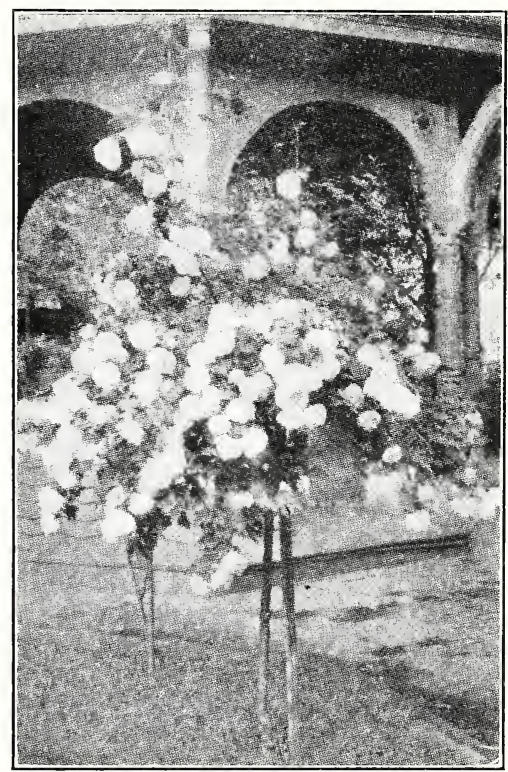

OLD-FASHIONED SNOWBALL

SNOWBALL. Japanese. Vib. tom. plicatum(F.) 6-8 feet. White. May. This species is one of the most satisfactory shrubs grown. Its pure white, double blossoms with a setting of dark plaited leaves and perfect form make it one of the best. Fine for an individual specimen or in groups.

2 to 3 feet. ...................... 1.00

3 to 4 feet. .

1.50

SNOWBALL. Common. Viburnum o. sterile10-12 feet. White. May. This old-fashioned variety is well known to every lover of plants. Its balls of pure white literally cover the bush when in bloom................. $\$ .75$ and $\$ 1.00$

SALIX CAPREA (Pussy Willow). A small shrub-like tree which is quick-growing and has furry catkins in spring which make it very attractive and desirable.

3 to 4 feet.................. .75

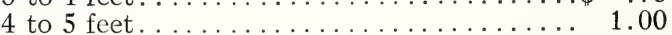



SPIREA. S. Anthony Waterer-(F.) 2 feet. Bright Pink. June and July. A compact, lowgrowing shrub with dense foliage usually deep green with occasional variegated leaves of pink and white on young growth. Flowers are borne in full, flat clusters on erect stems. If these are cut away when they fade the shrub will usually bloom intermittently during the summer. Very valuable for edging in front of shrubbery or sometimes used as a dwarf hedge.......... $\$ .35, \$ .50$ and $\$ .75$

S. Van Houtte (Bridal Bower or Bridal Wreath). -(F.) 4-6 feet. White. May. This is the most useful of the hardy shrubs. It has grown so popular that we sell more of it than any other variety we grow. The flowers are in flat clusters, usually an inch or more across, produced on spreading, pendulant branches often drooping to the ground. In full bloom they are a mass of white and never fail to attract attention. The foliage is an attractive green which it retains late in the year. This variety can be used in any location for hedging, grouping and mass effect. There is nothing superior in the catalogue. When in doubt what to use, plant Spirea Van Houtte... .\$.35, \$.50, \$.75 and $\$ 1.00$

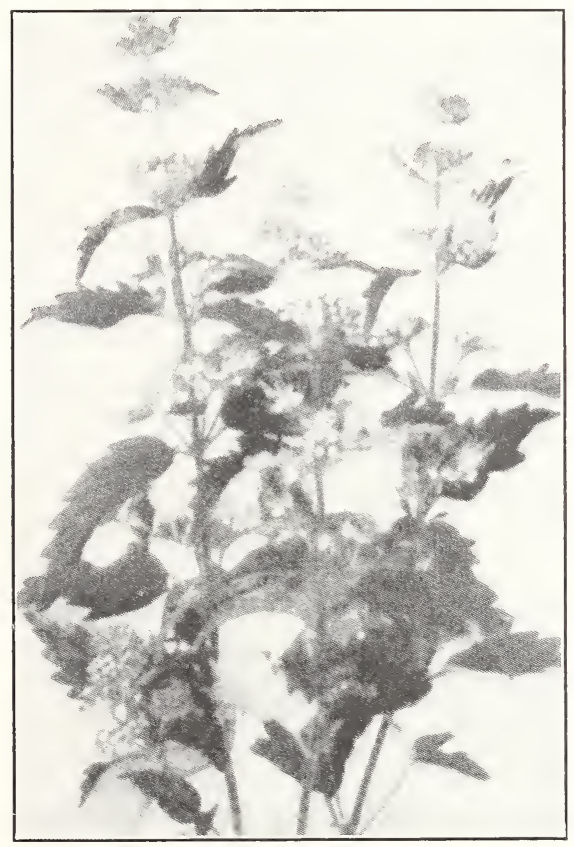

CARYOPTERIS MASTACANTHUS OR BLUE SPIREA

BLUE SPIREA, Blue-This is one of the rare blue-flowering shrubs. Grouped with white or delicate shades of pink spirea, it makes a colorful mass in early spring and summer.

$\$ .35, \$ .50$ and $\$ .75$

S. Callosa Rosea-(F.) 3 feet. Deep pink. June and July. Really a taller form of Spirea Anthony Waterer. A little more open in growth and if blossoms are cut away it will flower most of the summer..................\$.50 and $\$ .75$
S. Prunifolia-(Plum-leaved Spirea.) (F.) 5-6 feet. White. April and May. This is an oldfashioned variety, flowers borne close to the slender, erect branches in the spring before foliage appears. The individual flowers resemble miniature roses and are usually borne in great profusion. The foliage is shiny dark green and in the fall turns bright red..............\$.50 and $\$ .75$

S. Reevesii-(F.) 4-5 feet. White. May. This is one of the best of the Spirea group. White flowers, borne along the stem just as the foliage appears............. $\$ .35, \$ .50$ and $\$ .75$

S. Thumbergii (Snow Garland.)-(F.) 21/2-31/2 feet. White. April. The extra early flowering species is the pride of the Southland. It is spreading in growth with arching, slender branches that are a perfect mass of minute flowers followed with exceptionally delicate green foliage. For edging purposes it has few equals and we recommend it highly................35, $\$ .50$ and $\$ .75$

\section{THUMBERG'S BARBERRY}

Berberis Thumbergi-This Japanese shrub is being used more and more as a hedge. Not as quick in growth as Privet, but absolutely hardy. Its small, glossy leaves are out early in spring, succeeded by yellow flowers. The foliage turns a bright red in the fall and this is followed by red berries. It is a graceful, drooping shrub, making an elegant variety for hiding foundation walls or planting in the corners by steps, etc. Also does well in shady places. Especially remarkable for its brilliant red berries, remaining fresh until spring, and for its dazzling fall coloring. Our heavier bushy plants will make immediate effect when planted.

15-inch, per hundred.

.$\$ 12.00$

18-inch, per hundred.

25.00

24-inch, per hundred. . . . . . . . . . . 50.00

Single plants, sheared......\$.35, \$.50 and $\$ .75$

\section{SPECIAL OFFER OF FLOWERING SHRUBS}

12 plants assorted, our selection:

2 to 3 feet, for.

$\$ 2.75$

3 to 4 feet, for.

3.25

4 to 5 feet, for

4.25

WAYFARING TREE. Viburnum Lantana-(F.) 10-12 feet. White. June. A large, vigorous shrub with soft, heavy, lantana-like leaves and large clusters of white flowers in May, succeeded by red berries which turn black as they ripen ....... \$.75

\section{WEIGELA}

WEIGELA. Rosea-(F.) 4-5 feet. Pink. May. The most popular Weigela sold to-day. Its delicate pink, bell-shaped blossoms are borne in great profusion along great arching canes. There is also a scattering of blossom throughout the summer. The leaves are large and especially free of disease. This variety is the best of the group and is good for all uses where a shrub this height is needed. $\$ .35, \$ .50$ and $\$ .75$ 
WEIGELA. Red. W. Eva Rathke-(F.) 31/2-4 feet. Crimson. June. Of smaller growth than the other Weigelas. It is decidedly spreading in character of growth and also attracts attention in bloom with its brilliantly colored flowers with white throats. It is especially showy and if given preference of light soil and slight shelter will prove an excellent variety.

$\$ .75$

SUMAC. Staghorn. R. Typhina -10-12 feet. A large shrub or tree much used in landscape back-ground work. Brilliant red foliage in the fall.

4 feet. .

.$\$ 2.00$

SYRINGA. See Mock Orange.

TAMARIX. Five-stamen. T. pentandra. Often called T. aestavalis(F.) 6-7 feet. Pink. June. Shrubs with strong, but slender, delicate growth. Filmy, blue-gray foliage similar to asparagus with carmen-pink flowers in June and scattered blossoms the balance of the summer making it an unusually desirable shrub. Will grow in poor and dry soil. $\$ .50$ and $\$ .75$

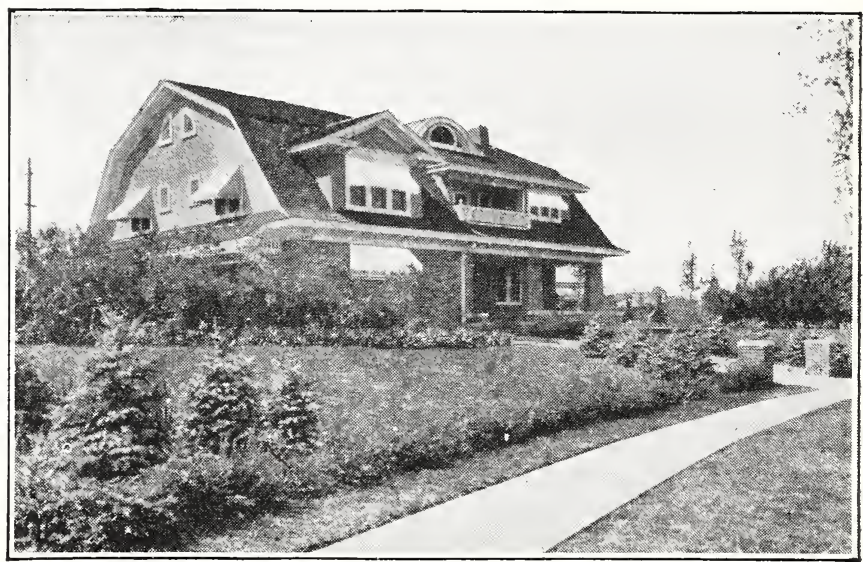

WELL PLANTED GROUNDS GIVE THE HOME AN INVITING APPEARANCE

\section{HEDGES-BEAUTIFY AS THEY SERVE}

For boundary, screen or barrier there is nothing more pleasing than a hedge fence. With their bright green leaves they constantly bring a feeling inspired by the fresh foliage of spring. When formally trained or left to develope naturally their arched branches, colored foliage and bright berries are surely more pleasing than the mechanical effect obtained by the similar use of wood or metal. Most hedges are permanent and with the exception of occasional shearing they need little attention after being established.

\section{PLANTING}

The distances vary according to the conditions. Where an impenetrable hedge is wanted plant the Privets 6-10 inches, Japan Barberry 8-12 inches and the flowering shrubs 12-18 inches apart. Where height is wanted rather than thickness then double the distance. The size of stock purchased will make but little difference in planting distance. In planting, place as deeply or slightly deeper in the trench than they stood in the nursery row and firm well. Most hedges should be severely pruned at planting time. It seems as though you are cutting away good wood but to encourage growth from the bottom it is necessary to do this.

The after pruning should consist of clipping the young growth at regular intervals. There is no special time except it might be well to avoid late pruning in the fall as this encourages young growth that is frequently killed by severe weather.

\section{CALIFORNIA PRIVET}

Ligustrum Ovalifolium-A semi-evergreen hedge with thick, shining, leathery leaves, that grows very rapidly, can be pruned into any formal effect and planted by every one needing a quick hedge without much expense and trouble. It blooms in spring, the fragrant white flowers being noticeable for some distance. In planting it is a good idea to cut away practically all the tops of the smaller plants in order to get a bushy hedge. We have quantities of this desireable variety.

2 feet, per hundred.............. 3.50

2 feet, per thousand ................. 30.0

\section{AMOOR RIVER PRIVET, SOUTH}

Ligustrum Amurense-Semi-evergreen hedge that grows quickly. Occasionally it freezes to the crown in a severe winter, but always comes back with renewed vigor.

18-inch, per hundred.............\$ 4.00

24-inch, cut back, per hundred......... 8.00

Specimens.................50 to 2.50

\section{REGEL'S PRIVET}

Ibota Regelianum-This is the hardiest of the Privets we sell. It is semi-drooping in growth, making thick hedges from the ground line, growing 6-8 feet, if left unsheared. Those wanting real permanency, or privacy, where a low hedge is wanted, plant this one.

3 feet, Specimen, each...........\$2 2.50 


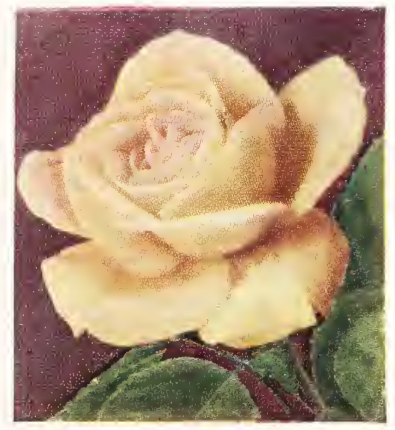

OPHELIA

\section{ROSES}

Field-Grown, Heavy Own-Root Roses, Two and Three-Year, 75c each; $\$ 8.00$ dozen

Ophelia-(Wm. Paul \& Son, 1912.) Outdoors as well as in the grcenhouse, this rose has taken a high rank. Its blooms are large in size, full and perfect in form and appearance and of attractive light salmon-flesh shading to yellow. The plant is vigorous, reliable and persistent.

Souvenir de Georges Pernet-Per. (Pernet-Ducher, 1921.) Seedling X Mme. Edouard Herriot. Very large blooms of Orient-red with carmine and yellow shadings. Vigorous in growth.

Doris Trayler-HT. (S. McGredy \& Son, 1924.) Bud orange cadmium, outside of petals being heavily flushcd crimson red and orange. Flower changes to deep amber yellow which does not fade. Flowers full.

Kaiserin Auguste Viktoria-HT. (P. Lambert, 1891.) Coquette de Lyon X Lady Mary Fitzwilliam. Creamy white flowers of immense substance, smooth, and nicely arranged.

Talisman-HT. (Montgomery Co., 1929.) Seedling of Ophelia X Claudius Pernet. The highest colored rose yet produced; scarlet and gold, with foliage vivid light green; straight, stiff stems, with cup-shaped buds. Very free. Awarded Gold Medal by American Rose Society.

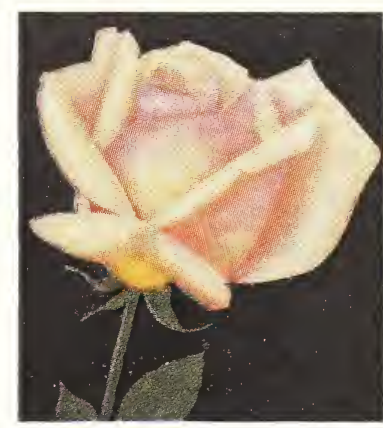

DORIS TRAYLER

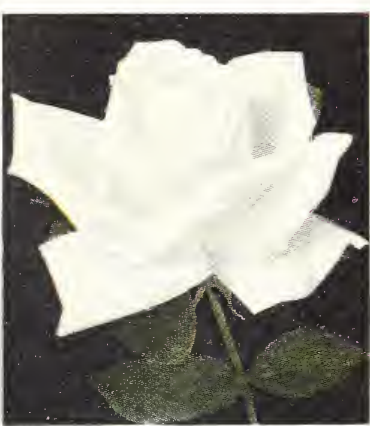

AUGUSTA VICTORIA

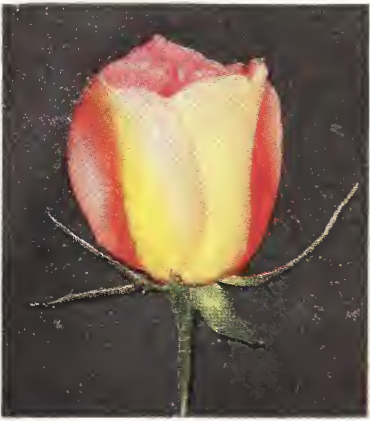

TALISMAN 


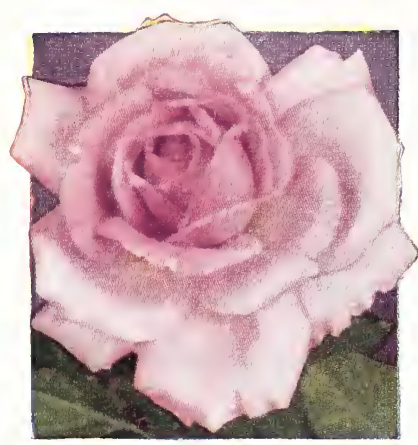

MME. CAROLINE TESTOUT

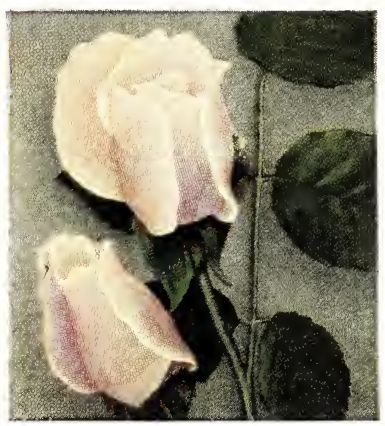

MRS. AARON WARD
Mme. Caroline Testout-HT. (Pernet-Ducher, 1890.) Lady Mary Fitzwilliam $\mathrm{X}$ Mme. de Tartas. Clear, bright satiny pink.
Mrs. Aaron Ward-HT. (Pernet-Ducher, 1907.) Sport from an unnamed seedling. Center Indian-yellow with edge primrose; medium-sized flowers, free and full.

Paul's Scarlet Climber-HW. (Wm. Paul \& Son, 1916.) The most brilliant rose known, because of its clear, vivid shining scarlet in large, semi-double flowers which remain unusually long and in good condition on the plants. The flowers never turn blue, but retain their intense coloring until the petals fall. May be used either as an ordinary climber or effective pillars which are a flame of scarlet when in bloom.

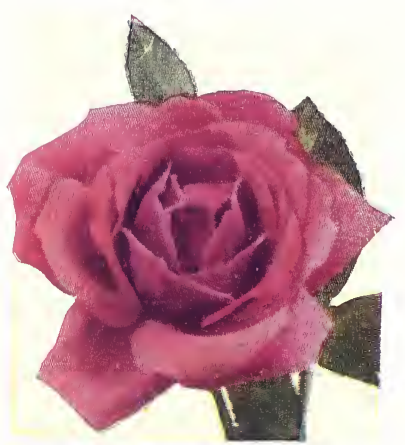

Climbing American B e a uty-HW. (Hoopes, Brother \& Thomas Co., 1909.) R. Wichuraiana Seeding $X$ American Beauty. Heavy, strong grower, hardy everywhere. Color rich red, passing to crimson. Very popular.

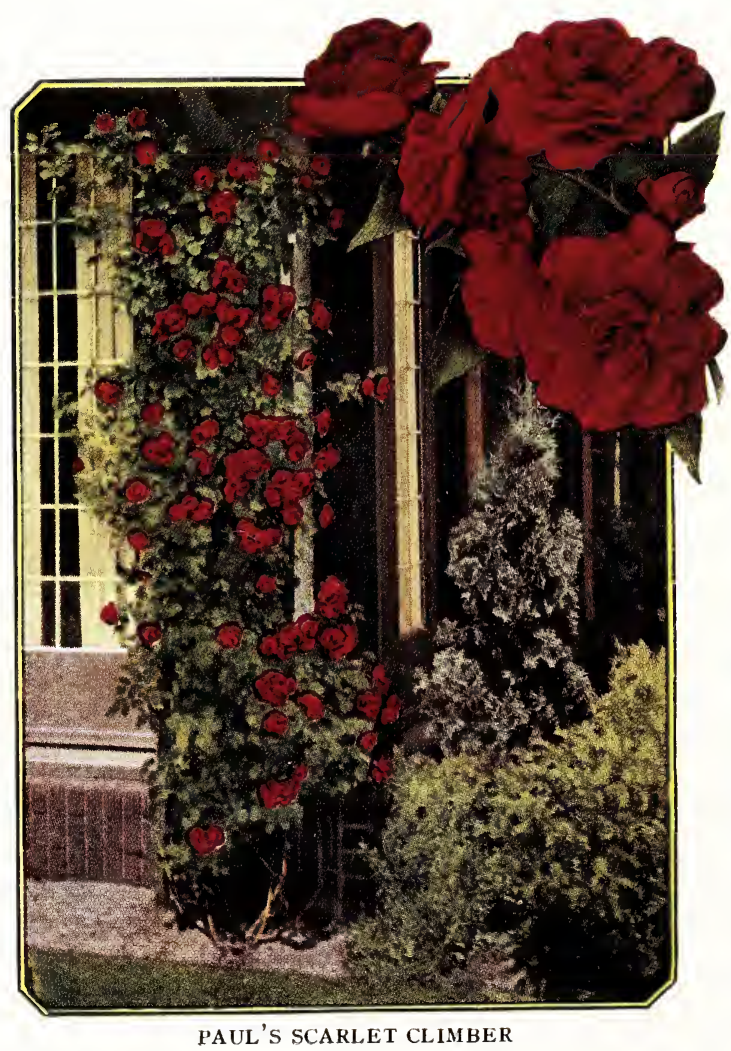

PAUL'S SCARLET CLIMBER 


\section{AMERICAN GROWN ROSES}

After years of breeding, experimentation and testing, rose varieties have advanced many steps beyond the garden of our grandmothers, so wonderful in June. Now we may have a succession of bloom all through the growing season, in colors and shades to suit every fancy. They can be used everywhere a foliage plant or blossom is wanted, or trained to ramble over fence, trellis or arch, embankment, walls or abutments, or entwined about posts, trees or pillars.

\section{SUGGESTIONS FOR ROSE CULTURE}

Plant only in a sunny position in soil free of all tree roots and protected, if possible, from severe weather.

\section{SOIL}

Roses like fertile, well-drained soil and if one will prepare a bed especially well, he will be rewarded in wealth of bloom and vigor of plant. An ideal top-soil would be sod from a pasture mixed with well-rotted cow manure on clay sub-soil.

\section{PRUNING}

In planting, prune them back to three or four good buds as they will grow off much better. The ever-blooming roses should be shortened back each year about one-half the previous season's growth. The ramblers may be pruned by taking out the older canes after they are through blooming, leaving only the younger canes, or by removing the flower spikes from the old canes. Our plants are own-root and field-grown and not the small pot roses usually offered.

Winter protection in the way of soil mounded up several inches about the plant, straw, manure, leaves or litter, especially about the tender varieties, repays in flowers the extra trouble.

\section{ENEMIES}

While healthy and vigorous plants are not especially susceptible to disease or pests, some pests will appear. For the leaf-eating insects, chafers, slugs and beetles, use arsenate of lead. For aphis or leaf hopper use kerosene emulsion or if diseases, leaf spot or mildew, use bordeaux mixture. Potassium sulphide, one ounce to three gallons of water, controls mildew better than anything else.

The list we offer contains the "cream" of the ones that do well here. The Hybrid Teas are the ever-blooming types, a little tenderer but bloom over the entire season. Hybrid Perpetuals bloom profusely in June, then follows a scattering of blossoms until frost.

\section{Roses Are One of Our Specialties}

\section{TEA AND HYBRID TEA}

Agnes-H. R. (Saunders, 1922). Copper-yellow buds and flowers which become pale gold upon opening. Well shaped for the Rugosa type, fragrant and freely produced in early summer. Foliage gray, much pitted and wrinkled. Growth moderate, but hardy.

Angele Pernet-HT. (Pernet-Ducher, 1924.) Brownish orange blooms of excellent shape, although only semi-double, and the color is well retained; some fragrance. Plant of moderate, bushy growth and seems to be a steady bloomer.

Arthur R. Goodwin-HT. Copper.

\section{Betty-HT. Coppery-rose.}

Betty Uprichard-HT. (A. Dickson \& Sons, 1922.) Copper-red buds, opening to flowers of above average size; brilliant orange carmine on outer surface of petals, showing light salmon reflexes; fragrant.

Cambria-Per. 1921. Sport from Mme. E. Herriot with all the characteristics of its parent; bright apricot with crimson markings on outside of the petals when in bud.

Captain F. Bald-HT. (A. Dickson \& Sons, 1919.) Velvety-black with scarlet-crimson sheen; very fragrant. Vigorous.

Charles K. Douglas-HT. (H. Dickson, 1919.) Flaming scarlet, flushed velvety-crimson, sweetly scented. Vigorous, upright grower.

Charles P. Kilham-HT. (G. Beckwith \& Son.) Brilliant orange, orient red, suffused with glowing scarlet. When open fades to brilliant Lincoln pink. Last a long time when cut. Tea scent. Awarded Gold Medal of the National Rose Society, April, 1927.

Columbia-HT. (Hill, 1917.) Ophelia X-Mrs. George Shawyer. Peach-blow pink, deepening as it opens, resembling a perfect Mrs. George Shawyer rather than the other parent, Ophelia. A large rose with long, stiff stems, nearly thornless, free from mildew; vigorous.

Columbia, Silver-Silver Columbia.

Commonwealth-HT. (Montgomery Co., 1922.) Bud large, long, pointed; flower large, double, very lasting, deep pink, on medium strong stem; moderate fragrance. Sufficient foliage and disease resistant. Continuous bloomer.

Crusader-HT. Velvety-crimson.

Dame Edith Helen-HT. (Alex Dickson \& Sons, 1926.) Glowing pink, holds color with age. Carried on rigid erect stems, large and full, of perfect spiral form, opens well in all weather. Old Rose scent. Foliage abundant, bright bronze to natural green, mildew and blackspot resistant. Vigorous, upright, free branching and flowering.

Doris Dickson-Per, (1926) orange.

E. G. Hill-HT. (E. G. Hill Co., 1929.) The flower is scarlet, shading to a deeper pure red as it develops. It produces long stems naturally and the foliage developes freely and is of fine color. A good producer and an unusually good keeper.

Etoile de France-HT. (Pernet-Ducher, 1904.) Mme. Abel Chatenay X Fisher Holmes. Rich velvety-crimson, center ruby-red; large and double. Likes hot weather.

Etoile de Holland-HT. Bright red, of medium size, fairly full; perfumed. Growth vigorous, upright.

Edel-HT. (S. McGredy \& Son, 1919.) White flowers that open ivory-white. Strong grower and free flowering.

Florex-HT. (Wm. Geiger, 1927.) Mme. Butterfly X Premier, coral salmon suffused carmine; free in bloom; needs no pinching. Strong, upright with long pointed bud of fine color. 
Geisha-Per. 1920. Flower pure deep orangeyellow; buds long pointed. Growth vigorous, quite hardy, green-bronzed foliage, perpetual flowering, sport of Mme. Edouard Herriot.

Golden Emblem-One of the most striking of the new roses, and a perpetual bloomer. It is a superb yellow in color, being richer and deeper than Rayon d'Or, and at its best rivals Marechal Niel in shape. The flowers are borne on long, upright stems, well above the glossy, holly-like green foliage, which is of wonderful substance and mildew-proof. Has been awarded several medals for its excellence.

Golden Pernet-Per. (Pernet-Ducher, 1928.) Brilliant, glowing, golden-yellow, becomes deeper and more intense with age. Long shapely buds. Free flowering, ample foliage, glossy, bronze-green, stems good.

Grillodale-HT. (N. Grillo, 1928.) Color delicate pink, profuse bloomer, is good outdoor rose. Long, pointed buds, full fragrant, on strong heavy stems.

Gruss an Teplitz-HT. (Geschwindt, 1897.) An extremely useful and dependable variety, succeeding well all over the United States. A profusion of beautiful, clear crimson-scarlet, fragrant flowers are borne from June until frost on a vigorous and shapely plant. An excellent bedder, and useful also as a hedge, if not cut back.

Georges Clemenceau-HT. (Leveque, 1919.) Per. Bright orange, shaded carmine-splendid color. Vigorous, free bloomer. Is a progeny of Mme. Edouard Herriot.

Irish Fireflame-HT. (A. Dickson \& Sons, 1913.) A very large, single flower of deep maddery orange, opening from spiral buds, passing to rich satiny old-gold veined with crimson.

Killarney-HT. (A. Dickson \& Sons, 1898.) Bright shell-pink; long pointed buds with large flowers. Very free and perpetual flowering.

Killarney Brilliant-HT. (A. Dickson \& Sons, 1914.) Sport from Killarney. Same growth and style as Killarney and, like it, varies considerably in color. In shady weather it is almost deep crimson.

Double White Killarney-HT. (J. A. Budlong \& Son Company, 1913.) A pure white sport from White Killarney but has a much larger bud and many more petals than its parent. A great forcing rose.

Los Angeles-HT. (Howard \& Smith, 1916.) Mme. Segond Weber X Lyon Rose. One of the finest roses ever introduced. The growth is vigorous, and produces a long-stemmed flower of a luminous flame-pink, toned with coral and shaded with translucent gold at the base of the petals. The buds are long and pointed. Bagatelle Grand Prize Rose.

Louise C. Breslau-Per. (Pernet-Ducher, 1912.) Soleil d'Or X unnamed seedling. Long, oval buds of coral-red, shaded with chrome-yellow, developing into fragrant, globular flowers which present other novel shades. The plant is a vigorous grower and has a robust constitution.

Lady Hillingdon-One of the best Tea Roses of its color-deep apricot-yellow throughout. It varies from medium to large size and is very beautiful in both bud and flower. The bush is hardy, a vigorous grower and bears flowers in abundance.
Lady Ursula-HT. (A. Dickson \& Sons, 1908.) Large, well-formed blooms with thick petals of light flesh-pink, without much shading; good fragrance.

Lulu-HT. 1919. Splendid buds of great length and delicacy of form, brilliantly shaded orange-pink and copper, borne on fine stems. Bush is very vigorous, free flowering and highly resistant to disease.

Maman Cochet-T. (Cochet, 1892.) Coralpink, shaded with salmon-yellow, and outer petals splashed rose; large and full, fine to cut.

White Maman Cochet-T. (J. Cook, 1896.) Cream-white with edges flushed rose. Otherwise same as the Maman Cochet, from which it is a sport.

Margaret McGredy-HT. (McGredy \& Sons, 1928.) Large brilliantly colored double flowers of rich Oriental red, passing to carmine-rose, lasting a long time. The plant is of vigorous habit, free flowering; light spicy fragrance.

Miss Lolita Armour-Per. (Howard \& Smith, 1919.) In 1921 this rose won the Bagatelle (Paris) prize. Its fragrant blooms develop from wellshaped buds, chrome-yellow at the base, shading to orange and copper hues on reverse of petals. Free blooming.

Mme. Pernet-Ducher-HT. Yellow.

Mrs. Henry Morse-HT. Pink-shaded salmon.

Mme. Butterfly-HT. Salmon.

Mme. Butterfly-HT. (E. G. Hill Co., 1918.) A sport of Ophelia, showing better growth, with more and larger flowers in a brighter pink, suffused apricot and gold. The plant is free and fine in growth and habit.

Mme. Edouard Herriot-Per. (Pernet-Ducher, 1913.) Coral-red, shaded with yellow and bright rosy-scarlet. Made famous when it won the London Daily Mail Gold Cup in 1912. Strong plants with bright green, glossy foliage; thorns long. Must be protected against black spot. Gold Medal, National Rose Society; Silver Cup, Royal Horticultural Society; Roseraie de 1'Hay Cup.

Mrs. Henry Bowles-HT. (Chaplin, 1921.) Rosy-pink, shaded with salmon of lasting quality.

Mrs. Charles Lamplough-HT. (S. McGredy \& Son, 1920.) Large, lemon-yellow flowers of fine quality.

\section{Mme. Pernet-Ducher-HT. Yellow.}

Old Gold-HT. (S. McGredy \& Son, 1913.) Vivid reddish-orange with coppery-reddish and apricot shadings. Medium size, semi-double. Strong grower; mildew proof foliage; free bloomer.

Rev. F. Page Roberts-HT. (B. R. Cant \& Sons, 1921.) Flower of Marechal Neil yellow color, veined with buff in the bud and young stages, full and well formed and sweet fruity scent. Awarded the Gold Medal of the National Rose Society.

Radiance-HT. (J. Cook, 1908.) Enchanter X Cardinal. Brilliant, rosy opaline-pink; large, free, and of beautiful form with sweet fragrance.

Radiance, Red-Red Radiance. 
Roselandia-HT. (W. Stevent, 1924.) A fine new yellow rose, a sport from Golden Ophelia. A vast improvement on the original.

Rose Dawn-HT. (Edward Towill, 1925.) Bud large, long-pointed; soft rose-flesh with yellow base. Foliage abundant, light green, diseaseresistant. Profuse bloomer.

Souv d Mme. Boullett-HT. (Jos. PernetDucher, 1921.) Flower dark cadmium yellow, large and full, long bud. Bronze-green foliage. The progeny of Sunburst X unnamed variety.

Sunburst - The introducer of this wonderful rose describes it in these words: "Sunburst is a vigorous grower of robust constitution with erect or slightly spreading habit and few thorns; fine reddish-green bronzed foliage. The buds are long and generally borne on long, stout stems; the flowers are large, full, and of fine elongated, cupped form. The color is a superb cadmium-yellow.'

Wilhelm Kordes-HT. (W. Kordes Sohne, 1922.) Long, pointed buds and double, high centered flowers of deep golden yellow, over-spread with a tint of copper, and striped with red. Vcry fragrant and free flowering. Vigorous, compact growth.

Willowmere-Per. (Pernet-Ducher, 1913.) Unnamed variety $\mathrm{X}$ Lyon Rose. Color rich shrimppink, shaded yellow in the center and toning to carmine-pink towards the edges of the pctals. Long carmine-coral bud on long, stout flower-stalks. Vigorous growth, and erect, branching habit.

Wm. F. Dreer-HT. Pink to yellow.

William R. Smith-HT. Cream.

\section{HYBRID PERPETUAL}

American Beauty-HP. (Bancroft, 1886.) Originally named Mme. Ferdinand Jamin, but was imported by the historian, Bancroft, in 1886, and at his suggestion later introduced as American Beauty by a Washington florist. It is deep pink to soft carmine with delicate veining of dark red on the broad petals. Under proper care it is a strong grower.

Frau Karl Druschki-HP. (P. Lambert, 1900.) Merville de Lyon X Mme. Caroline Testout. Pure snow-white; long-pointed buds; large, full flowers; free and constant. Not very fragrant.

General Jacqueminot-Crimson. A rich, velvetycrimson, changing to scarlet-crimson. A magnificent rose, equally beautiful in the bud state or open. The best known of all Hybrid Pcrpetuals, and is without a rival in fragrance and richness of color. It is perfectly hardy in most situations.

George Dickson-We might mention several hundred varieties of light-colored roses but there are few good sorts in the very dark shades. George Dickson is one of the few, even more, it is one of the best dark roses in existence. The blooms are as nearly perfect as those of any rose, large, full and fragrant. The color is decp velvety-crimson, almost black on the front of the petals, while the reverse side is heavily and deeply veined with rich crimson-maroon. Never blues, browns or seals.

J. B. Clark-HP. (H. Dickson, 1905.) Lord Bacon X Gruss an Teplitz. Intense, deep scarlet, heavily shaded blackish-crimson; large, full, with immense petals.

Paul Neyron-HP. (Levet, 1869.) Victor Verdier X Anna de Diesbach. Deep rose; immense size. Hardy and vigorous.
Prince Camille de Rohan-HP. (E. Verdier, 1861.) Thought to be from Maurice Bernardin $X$ Geant des Battailes. Rich, blackish marooncrimson; large and full. Vigorous.

\section{CLIMBERS}

American Pillar-Mult. The large, single flowers are a lovely shade of cherry-pink, with a clear white eye surrounding numerous golden-yellow stamens. The canes are of strong, vigorous growth, and bloom abundantly. The foliage is distinct and decorative, and the variety has no superior.

Alida Lovett-HW. (Dr. W. Van Fleet, 1905.) Wichuraiana Seedling $X$ Souvenir du President Carnot. Bright shell-pink with shadings of sulphur at the base of petals. It resembles Dr. W. Van Fleet, but is of a much darker color and the foliage is even more beautiful; mildew proof.

Christine Wright-HW. (Hoopes, Brother \& Thomas Co., 1909.) R. Wichuraiana Seedling X Mme. Caroline Testout. Heavy, dark green foliage which is immune to disease. Large, full flowers bornc singly and in clusters; perfect in form; beautiful in bud and in full expanded flowers; color bright, wild-rose pink. A popular rose in the East.

Caroline Testout-Cl. HT. Another strong grower, with foliage and flowers same as bush from which it is a sport.

C1. Duchess of Wellington-HT. (Howard Rose Co., 1924.) Same as bush in every way.

Etoile de France-Cl. HT. (Howard Rose Co., 1916.) Very vigorous. Always in flower throughout the heat of the summer and undoubtedly the best hot-climate climber on the list.

Gruss an Teplitz-Cl. HT. (Storrs \& Harrison, 1911.) A perfect sheet of crimson when in bloom. It's the same as the bush of Teplitz.

Lady Hillington-Cl. T. (Hicks, 1917.) We have seen this variety two years in the field and believe it is a vigorous grower and in every way as desirable as the bush.

Maman Cochet-Cl. T. (Howard Rose Co., 1918.) Another true sport of the bush variety so well known. Fortunately this sport is a strong grower.

Mme. E. Herriot-Cl. HT. (1921.) A vigorous climbing sport of the well known bush variety; flowers produced in great profusion.

Mrs. Aaron Ward-Cl. HT. (A. Dickson \& Sons, 1922.) A climbing sport of this well-known yellow variety. Vigorous and remarkably free blooming. Flowers identical with the bush variety.

Crimson Rambler-P. (Turner, 1893.) Too well known to need description.

Ophelia-HT. Salmon-pink.

Dorothy Perkins-HW. (Perkins, 1902.) R. Wichuraiana X Mme. Gabriel Luizet. Beautiful deep pink flowers. Too well known for further description.

Shower of Gold-HW. (Wm. Paul \& Son, 1910.) Jersey Beauty X Instituteur Sirdey. Deep golden-yellow, very double, free and lasting. Glossy, bronze foliage.

Silver Moon-HW. (Dr. W. Van Fleet, 1910. ) R. Wichuraiana Seedling X R. Laevigata. Pure white with clear yellow stamens; large; free. Glossy, bronze-green foliage. 
Sunburst-Cl. HT. (Stuart, Low \& Co., 1914.) Same as the well-known bush. It is strong, vigorous and quite hardy. Recommend it to our customers every time.

Dr. W. Van Fleet-HW. One of the most important climbing roses. It has a perfectly formed bud which is long and pointed, deep pink in color, and very solid. When fully expanded the outside petals are just faintly suffused pink, gradually deepening to a rich shell-pink center which is high and full. The full-blown flowers measure on an average 4 inches in diameter and are borne on long sturdy stems. The bloom has a pleasing scent, rendering it a valuable cutting rose. In addition to its wonderful profusion in blooming, the large glossy foliage has a great decorative value during the entire season.

Most Varieties of Climbers we list are Monthly Blooming. All Roses listed above are $75 \mathrm{c}$ each, or $\$ 8.00$ dozen.

\section{MISCELLANEOUS ROSES}

$$
\text { HW. HPol. TP. DP. }{ }_{\text {HR. }}^{\text {Per. WN. }}
$$

Price: $75 \mathrm{c}$ each; $\$ 8.00$ dozen.

Baby Catherine Zeimet-P. White.

Baby Doll-P. Yellow edged pink.

Baby Edith Cavell-P. Deep crimson.

Baby Ellen Paulson-P. Dark pink.

Baby Jessie-P. Cherry crimson.

Baby LaMarne-P. Salmon-rose.

Baby Orleans-P. Geranium-pink.

Conrad Ferdinand Meyer-HR. (Muller, 1900.) (Gloire de Dijon X Duc de Rohan) X R. Rugosa Germanica. This is about the best Hybrid-Rugosa you have ever known. It is an enormous grower and a free bloomer. The flowers are large, double, cup-shaped, intense pink, with the penetrating fragrance of the old June roses.
Pink Grootendorst-Very charming pink variety of the popular F. J. Grootendorst. NEW.

F. J. Grootendorst-H. Pol.-Rug. (De Goey, 1918.) This is a new type which might be called a Rugosa Baby Rambler, being a cross between Rugosa and the Crimson Baby Rambler. Imagine a shrub-like Rugosa covered with trusses of Crimson Baby Rambler Roses. It is absolutely hardy and continues in bloom until late in the fall.

George Elger-Long-sought-for yellow Cecile Brunner. This, with Cecile Brunner and Perle d'Or, are the best corsage varieties. They all have about the same foliage and should not be confused with the other hardy Polyantha "Baby" kinds.

Golden Salmon-P. (de Ruytea, 1926.) An intense golden salmon. Flowers medium in size, produced in large, full trusses. Strong, bushy growth of medium height. Healthy foliage.

Gruss an Aachen-DP. . (Geduldig, 1909.) Orange-red and yellow buds, and large, light flesh-pink and salmon-yellow flowers.

Harrisons Yellow-AB. (Harrison, 1830.) Bright yellow flower covering the bush early in he season. Very vigorous and with perfect healthly foliage.

Hugonis-(Rosa hugonis). Single, yellow and fragrant. A natural species.

Souvenir de Claudius Pernet-Per. (PernetDucher, 1920.) Constance X unnamed seedling. Awarded the Bagatelle prize. Its color is a definite and lovely sunflower-yellow, deepening in the center, and it retains this color indoors and outdoors, in bud and open bloom. The buds are produced on long, stiff stems.

Tip-Top-(Baby Doll). P. (Lambert, 1909.) Trier X R. fœtida bicolor. The color is golden yellow tipped with clear bright cerise, almost variegated. The buds and flowers are very perfect in form.

Willowmere-Per. Pink.

\section{HARDY PERENNIALS}

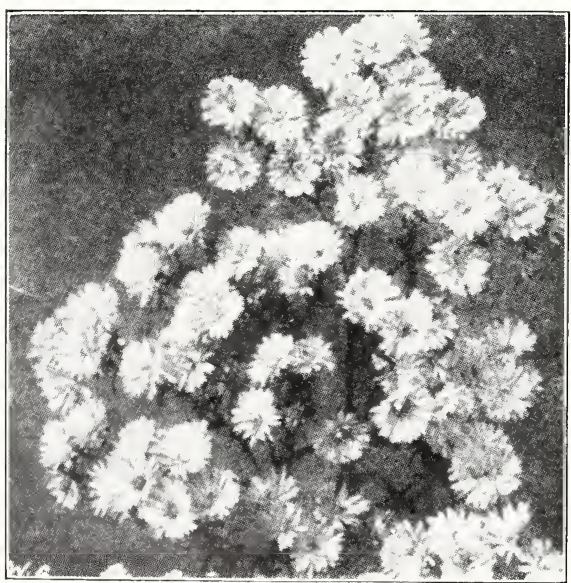

ASTER, NOVI-ANGLIAE

For permanent planting, for variance, for beauty of flower and pleasure, the perennial plants offer a field from which one may select in color or in period of bloom, plants to suit the tastes of the most fastidious. Our list includes only the most desirable ones. There are hundreds of varieties and kinds, many are meritorious, but for the average bed, group or border, one will find the selection that follows suitable to ordinary purposes.

\section{PLANTING SUGGESTIONS}

Ordinarily, perennials are set eighteen inches apart for the larger-growing and fifteen inches for the dwarf plants. In planting a border, if one will mark his rows going each way so as to make squares the number of plants is quickly ascertained, the arrangement as to height is easily arrived at and the grouping or planting made easy by alternating or varying a few inches from these rigid lines. Mulching, for winter protection, is necessary. Care must be taken not to smother the plants by covering the crowns.

May it be said that these plants thrive better in fertile ground and with plenty of moisture; should be well cultivated and kept free of weeds for best results. 


\section{PERENNIALS}

ACHILLEA Boule de Neige-(Ball of Snow). An improvement on the Pearl. Wonderful for cut flowers or garden......25c each, $\$ 2.00$ dozen

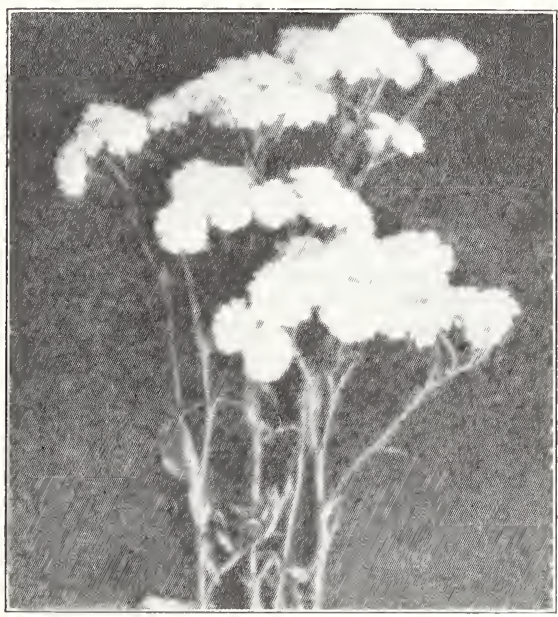

ACHILLEA PTARMICA, "THE PEARL"

ACHILLEA Millefolium Roseum-(Rosy Milefoil). Finely cut, deep green foliage; pink flowers in dense heads and found all summer.

$25 \mathrm{c}$ each, $\$ 2.00$ dozen

ACONITUM-(Monkshood). Summer and late autumn-flowering plants with bold spikes of hood-shaped flowers, thriving in either sun or shade. The roots are poisonous and should not be planted where the tubers might be mistaken for vegetables. Tubers cannot freeze.

Napellus (True Monkshood). 3 to 4 feet. July to August. Large dark blue flowers in a raceme.

$35 \mathrm{c}$ each, $\$ 3.00$ dozen

Anchusa-We offer the deep blue shade of this excellent perennial. It grows four to five feet, and sometimes needs staking. Blooms in May and the giant stalks are a mass of pretty blue flowers. For the background of a hardy border this is indispensable where blue color is wanted. 4 to 6 feet..............25c each, $\$ 2.00$ dozen

Aquilegia-COLUMBINE-Blooming in late spring and through the early summer months, preferring slightly shaded positions, though it does well in the sun. The flowers are borne on slender stems and mostly long spurred. Coming in the many shades they do, prove very valuable in any border. 2-3 feet.

Mrs. Scott Elliott Hybrids-There is not a better mixture grown in the world than by Mrs. Scott Elliott, who has taken the highest awards at all the European exhibitions. Wonderful colors with very long-spurred flowers. Our stock is from seed from this source, absolutely true strain.

Long Spurred Hybrids. Mixture.

$25 \mathrm{c}$ each, $\$ 2.00$ dozen

\section{ARTEMISIA (Sage Brush)}

Silver King-A striking white-leaved contrast plant. A beautiful "mist" for setting off bouquets and floral combinations. The entire color effect bright frosted silver. 3 feet high. Sprays may be cut to mix with Winter bouquets.

$25 \mathrm{c}$ each, $\$ 2.50$ dozen

\section{NOT LESS THAN SIX OF A KIND SOLD AT DOZEN RATES}

ASTERS, Hardy-(Michaelmas Daisies). These are among the showiest of our late flowering hardy plants giving a wealthy bloom during September and October...........25c each, $\$ 2.00$ dozen

Climax-One of the best and showiest, with large pyramidal spikes of large, light, lavenderblue flowers. Very free. 5 feet $.25 \mathrm{c}$ each, $\$ 2.00$ dozen

Feltham Blue-A pretty aniline blue, very free. $25 \mathrm{c}$ each, $\$ 2.00$ dozen

Novae-Angliae Rosea-Deep reddish violet. Height, 4 feet............25c each, $\$ 2.00$ dozen

St. Edgwin-One of the finest, covered with beautiful pink flowers......25c each, $\$ 2.00$ dozen

Beard Tongue or Penstemon-Has tall spikes of brilliant scarlet, tubular shaped and bearded flowers. 4 feet. Period of bloom, July and August. $25 \mathrm{c}$ each, $\$ 2.00$ dozen

\section{CALLIRHOE (Poppy Mallow)}

Involucrata-Trailing plant, with finely divided foliage and large, saucer-shaped flowers of bright rosy crimson, with white centers, which are produced all Summer and Fall.......25c each, $\$ 2.00$ dozen

Campanula-CANTERBURY BELL-Another garden favorite. Blossoms borne on long stems in many shades and colors. Partial shade and rich soil produce the better blossoms. This is a biennial but should be in every garden. May and June. $21 / 2$ to 3 feet. Blue........25c each, $\$ 2.00$ dozen

Carnations-These are the hardy border carnations. We offer these in mixed colors. The flowers are medium sized and have all the characteristics of the varieties grown under glass. 1-2 feet. June to September.........25c each, $\$ 2.00$ dozen

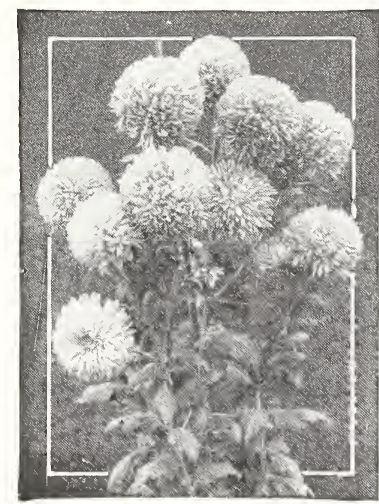

CHRYSANTHEMUMS 
Chrysanthemums-These are hardy and most attractive in September and October. In planting these try to group them as some seasons it may be necessary to save from early frost by covering. Height, 2-3 feet. The flowers are very attractive, borne in large quantities.

CHRYSANTHEMUM M A X I M U M-(Giant Moonpenny or Shasta Daisies).

$25 \mathrm{c}$ each, $\$ 2.00$ dozen

Alaska-Extra large....25c each, \$2.00 dozen

Arcticum-(Arctic Daisy). Among fall flowering perennials this is one of the best. It forms an attractive clump of dark green foliage, and in September multitudes of white flowers, slightly tinged rose or lilac, 2 inches wide, appear. 2-21/2-feet. September and November...25c each, \$2.00 dozen

King Edward VII-New, Vigorous grower; enormous white flowers.....25c each, $\$ 2.00$ dozen

HARDY CHRYSANTHEMUMS. Autumn Glow -Rose-Crimson, Large. Excelsior-Bright OrangeYellow. Golden Queen-Yellow, Large. VictoryWhite, Large.

Red, Large (New), each . $\$ \quad .75$

Coreopsis-A beautiful yellow flower, desirable for cutting or for border. After blooming, the seed may be cut away and a good secondary blossoming will follow all through the summer. Height, 2-3 feet. Graceful. June to August... . 25c each, \$2.00 dozen

Delphinium, Light Blue, Belladonna-The praises of this variety have been sung by every lover of the hardy border. Light turquoise blue flowers are borne in spikes, the first coming in June. These may be cut away and young growth will start from the crown, producing blossoms all summer. Height, 3-4 feet. Mulch lightly, as crown sometimes rots in winter..............25c each; \$2.00 dozen

Delphinium, Dark Blue, Bellosamum-This is an improved dark blue with all the other characteristics of the preceding. 3 feet. June to September. 25 c each, $\$ 2.00$ dozen

Delphinium, English Hybrids-These are taller growing, being 4-5 feet, and in all shades of light and dark blue. June to September.

$25 \mathrm{c}$ each, $\$ 2.00$ dozen

Wrexham Strain. 35c each, \$3.00 dozen

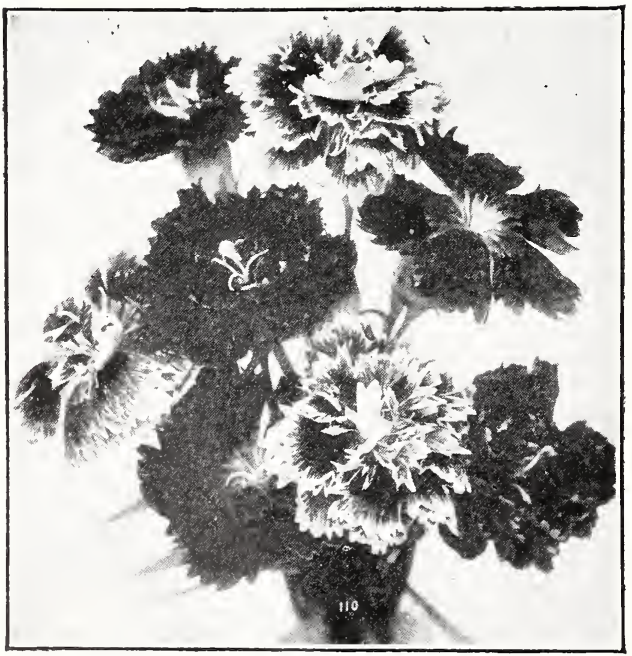

DIANTHUS OR HARDY PINKS
DIANTHUS Barbatus-(Sweet William). Old favorites, bearing their sweet, clove-scented flowers in the greatest profusion during May and June. They are indispensable for the edge of the hardy border and for cutting.

Atro-Sanguineus-Blood-red.

25 c each, $\$ 2.00$ dozen

Pink Beauty-Improved fine deep salmonpink color .............25c each, $\$ 2.00$ dozen

Scarlet Beauty-Rich deep scarlet, bright green foliage, very fine.........25c each, \$2.00 dozen

DIANTHUS Plumarius-(Hardy Pinks). Plumarius fl. pl...........25c each, $\$ 2.00$ dozen

EUPATORIUM Ageratoides-Fine cut-flower; fall bloomer............25c each, \$2.00 dozen

Coelestinum-Simply covered with blue Agera. tum-like flowers in August and September. 2 feet. Fine for cutting........25c each, $\$ 2.00$ dozen

FOXGLOVE-Digitalis-This biennial is an old garden favorite. The flowers are borne on long stems (3-4 feet), and during their period of blossom are the most attractive thing in a border. These plants are not offered as to color, but are mixed seed from best plants. They are, ordinarily, very easy to grow, thriving in loose, rich soil. May and June.

FOXGLOVE-The Shirley-New. Magnificent strain, enormous flowers, pure white to deepest rose...............25c each, $\$ 2.00$ dozen

BOLTONIA Asteroides-Among the showiest hardy plants with large single Asterlike flowers. The plant is in bloom during the summer and autumn months with its thousands of flowers open at one time producing a very striking effect.

Latisquama-Lavender-pink. 4-5 feet. $25 \mathrm{c}$ each, $\$ 2.00$ dozen

GYPSOPHILLA Paniculta-(Baby's Breath).A beautiful old-fashioned plant possessing a grace not found in any other perennial and attracting the eye of everyone. Dense, spreading bush, numerous tiny flowers in light, feathery panicles, delicate foliage, fine for cutting, excellent for border or large rock gardens. July and August. Strong, two-year-old roots. . . . . . . .25c each, $\$ 2.00$ dozen Bristol Fairy, New.............75c each

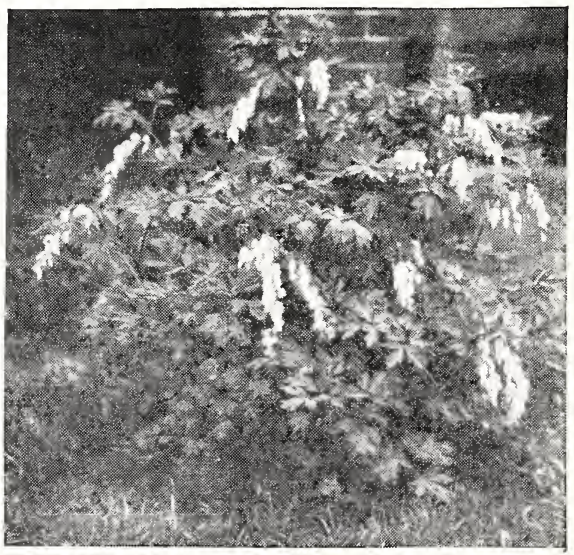

DICENTRA OR BLEEDING HEART

Bleeding Heart or Dicentra-An old-time favorite. Its arching stems bear dropping heartshaped flowers of white and old rose. Grows in shade. 1-2 feet. May and June. Each......\$.75 


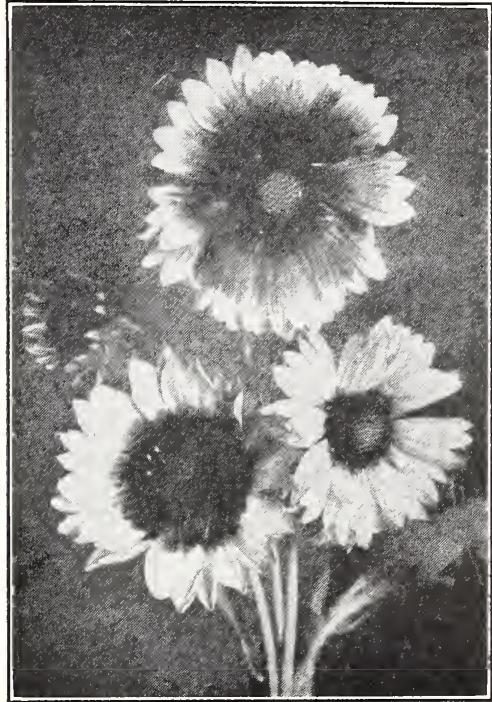

GAILLARDIA

Gaillardia-BLANKET FLOWER-Will grow anywhere, bearing large quantities of yellow flowers, flecked and marked with crimson and brown. Starting in June, there are blossoms all summer. One of the most desirable plants for the home garden and the flowers are valued for cutting. 2 to 3 feet............25c each, $\$ 2.00$ dozen

Geum or Avens-A new border plant producing large dazzling scarlet flowers. 1-2 feet. May to July................25c each, \$2.00 dozen

Helianthus-SUNFLOWER-Miss Mellish-A beautiful yellow, blooming in August and September, flowers being two inches across and on strong stems. The flowers are single and the foliage free from disease. Spreads quickly and produces tall stalks. $5-7$ feet............25c each, $\$ 2.00$ dozen

HEMEROCALLIS. Thumbergii-Much like Flava, but flowers in July, a month later, and 6 to 10 inches of the upper portion of the flower scapes are thickened and flattened.

\section{5 c each, $\$ 2.00$ dozen}

Minor-Dwarf, lemon yellow. First of June. $25 \mathrm{c}$ each, $\$ 2.00$ dozen

\section{HELENIUM Autumnale Superbum-Light} yellow . . . . . . . . . . 25c each, $\$ 2.00$ dozen

Hollyhocks-Everyone knows them-with their long spikes of multi-colored flowers, borne in profusion as they are, there is no wonder they are so largely used. Blooming in June and July, so absolutely hardy that they will take care of themselves..............25c each, $\$ 2.00$ dozen

\section{BULBS}

Cannas and Gladiolus; Hyacinths and Tulips in season. Ask for List.

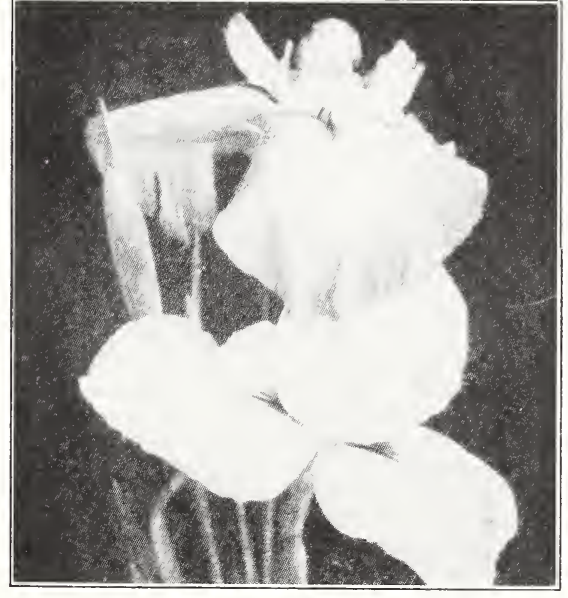

IRIS KAEMPFERI-JAPANESE IRIS

\section{JAPAN IRIS}

This is the latest blooming of the Iris. Anyone not familiar with these has missed one of the glories of the garden. They bloom in June, being the largest, showiest and contain varieties that for variance of color and beauty are unsurpassed by any perennial. Prefers moist soil, but blooms exceedingly well on any type. We are limited in several varieties and will have to substitute if sold out when order is received. We list six varieties to color and letter as the names are difficult to pronounce. They are all delicately and variously veined and shaded, all being favorite sorts.

White.

Dark Purple.

Rose.

Lavender. .

Mahogany

$35 \mathrm{c}$ each, $\$ 2.50$ dozen

\section{SIBERIAN IRIS}

Resembles the Japanese varieties in character of growth. Blooms earlier. Purple veined, gold and white in color. $25 \mathrm{c}$ each, $\$ 2.50$ dozen.

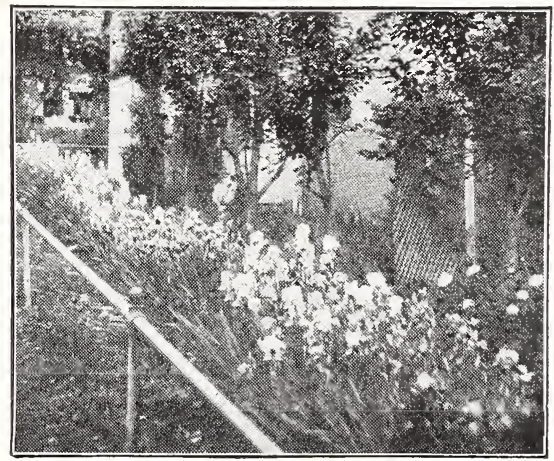

HEDGE OF IRIS

\section{IRIS}

There is a peculiar charm about the Iris that appeals irresistibly to those whose taste for the refined and delicately beautiful leads them to seek a closer acquaintance with it. Its irridescent coloring, fragile, orchid-like formation is often 
unnoticed by the careless observer. But those who only know the Iris as "flags" have never really examined "the rainbow flower," "messengers from the Queen of Heaven to mortals on earth." We want you to plant some of them and see that one investment means years of beauty. They will last indefinitely when once established.

\section{GERMAN IRIS}

These are the old-fashioned Iris, and the varieties we offer are exceptionally meritorious, being selected for variety and distinct coloring.

Black Prince-Standards light lavender; falls lavender.

King-Standards lemon-yellow; falls satinybrown, edged sulphur.

Loreley-Falls slightly yellow, heavily veined purple; standards yellow.

Pallida Dalmatica-A tall variety. Lavender, shading to blue.

Pauline-A striking lavender-violet variety.

Sherwin Wright-A golden-yellow with practically no marking.

Spectabilis-The old-fashioned royal purple variety.

Queen of May-A soft rose-lilac, almost pink.

Walneri-Standards lavender; falls a purplelilac.................25c each, \$2.00 dozen

LATHYRUS. Sweet Pea, Perennial-This is a hardy vine, robust growing and fine foliage. Flowers in shades of pink, continuous blooming from June to frost..............25c each, $\$ 2.00$ dozen

LILY, Hemerocallis, Day-These are the popular lilies that thrive in any border. Like moist and semi-shaded location, but will grow anywhere. Color, yellow. June and July. 2-3 feet..............25c each, $\$ 2.00$ dozen

LILY, Funkia, Plantain-Pure white flowers with large, showy leaves. Especially fine for shady spots. 1-2 feet. July and August. .. 25c each, \$2.00 dozen

LINUM (Flax) Perenne Blue-May to August. Pearly-blue flowers. A graceful, hardy perennial. $25 \mathrm{c}$ each, $\$ 2.00$ dozen

LUPINE-Very valuable in the hardy border, giving an abundance of long spikes of delicately scented flowers in June and July. Height 3 feet.

Polyphyllus Type-Blue..35c each, \$3.00 dozen

Roseus-Rose pink......35c each, \$3.00 dozen

MALLOW MARVELS-A giant race derives from the common native Hibiscus, which has elevated this type almost to the dignity of shrubs. Massed in great groups or generously interspersed with shrubs, these "Marvels" grow very rapidly, sometimes getting up to 8 or 10 feet in height; with plenty of broad foliage to furnish a rich setting for the mammoth flowers.

Crimson Eye-Strong, three-year old. Red or pink...............35c each, $\$ 3.00$ dozen

Marvel Mallows-In choicest mixture. Strong, three-year old...........35c each, $\$ 3.00$ dozen

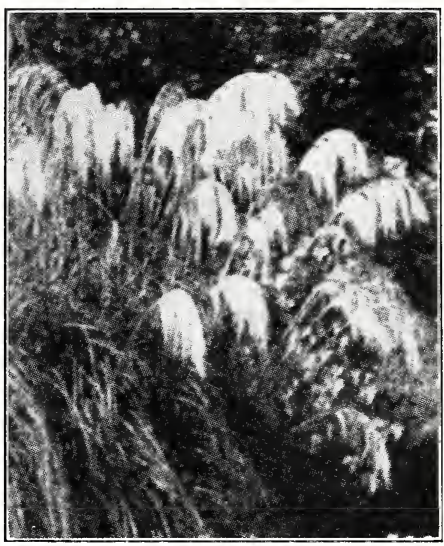

PAMPAS GRASS

\section{ORNAMENTAL GRASS}

Blue Lime Grass. . . . . . . . . . 25c each, \$2.50 dozen Plume Grass. . . . . . . . . . . .50c each, 4.50 dozen Japan Rush Grass......... 25c each, 2.00 dozen Blue Fesque Grass. . . . . . . . 25c each, 2.00 dozen Fountain Grass.......... 25c each, 2.50 dozen Var. Ribbon Grass........ . 25c each, 2.00 dozen Gracillis Grass...........25c each, 2.00 dozen Zebrina Grass..........25c each, 2.00 dozen Clumps of above Grasses . . . \$.50, \$.75 and $\$ 1.00$

\section{PHLOX SUBULATA}

(Moss or Mountain Pinks)

An early spring-flowering type with pretty moss-like, evergreen foliage, which, during the flowering season, in April and May, is hidden under the masses of bloom. An excellent plant for the rockery, the border, and invaluable for carpeting the ground or covering graves.

Lilacina. Light lilac. . . . 25c each, \$2.00 dozen

Rosea. Rose-pink. Fine for covering banks; thrives in hot, dry situations, and blooms profusely. $25 \mathrm{c}$ each, $\$ 2.00$ dozen

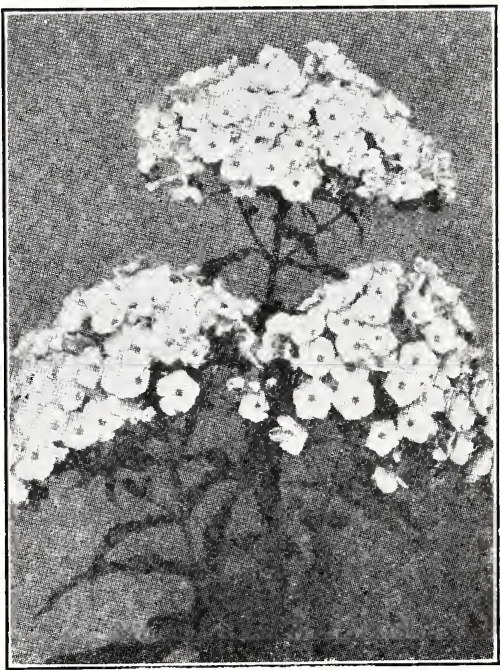

PERENNIAL PHLOX 


\section{PHLOX}

Nothing grows in the perennial class that is as satisfactory as the Hardy Phloxes. They are wonderful in their many shades, their profusion of bloom and general good character. Our list is not large but the very best varieties of their respective colors from a test row of many kinds. It is a good idea to break out the flowering spikes after they have finished blooming. Root-prune or transplant every few years.

Athis-Salmon-pink.

Eclaireur-Bright rose-carmine.

Fernand Cortez-Deep crimson.

Isabey-Salmon-pink.

Lothair-Bright crimson.

Michael Buchner-Lavender.

Miss Lingard-Earlicst whitc; pale pink eye; long graceful panicles.

Mme. Prosper Langier-Fine dark red.

Mrs. Ethel Prichard-Rose mauve.

Mrs. Scholton-Dark salmon-pink.

Siebold-Orange-scarlet; crimson center.

Sir Edwin Landseer-Bright crimson.

Von Hochberg - Brilliant red.

PENTSTEMON Barbatus Torreyi (Beard Tongue)-Slender spikes of bright scarlet flowers. 4 feet. June to August. . . .25 c each, \$2.00 dozen

Platycodon-JAPANESE BELLFLOWER - This comes in blue and white. Blossoming in July, the attractive flowers, often three inches across, come in succession for several weeks. Height, $21 / 2-3$ feet. $25 \mathrm{c}$ each, $\$ 2.00$ dozen

Pyrethrum-PAINTED DAISY-One of the most desirable perennials blooming in May and June. Attractive. We list mixed shades. 2-3 feet.

PYRETHRUM Hybridum (Painted Daisies)Red, white and pink mixed, blooms in June and July, a most beautiful hardy plant.

$25 \mathrm{c}$ each, $\$ 2.00$ dozen

Rudbeckia-GOLDEN GLOW-A yellow blooming perennial that has become popular in a very short time since being introduced. The flowers, in July and August, are like small Chrysanthemums borne on the terminals of 5-6 foot stalks. Very desirable..............25c each, \$2.00 dozen

Rudbeckia Purpurea......25c each, $\$ 2.00$ dozen

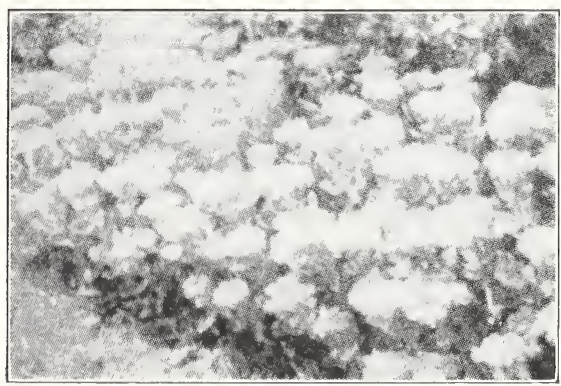

SEDUM SPECTABILE
SEDUM-Has thick glaucous foliage; drouth resisting and suitable for rockery or border.

Acre-Golden Moss; Stonecrop. Useful plant for rockeries and for edging borders. Flowers bright yellow. 2 to 3 inches. May to July. $25 \mathrm{c}$ each, $\$ 2.00$ dozen

Asiaticum-Flowers deep rose. 6 to 8 feet. July and August........25c each, \$2.00 dozen

Spectabile-Erect growing mass of rose colored flower heads 18 inches high. August and September. 2 year..............25c each, $\$ 2.00$ dozen

SALVIA Azurea (Meadow Sage)-A Rocky Mountain species. Grows 3 to 4 feet high, producing during August and September pretty skyblue flowers in the greatest profusion.

Pitcheri-Blue.......25c each, \$2.00 dozen

SCABIOSA Caucasia. (Pin Cushion Flower) (Blue Bonnet)-A soft and charming shade of lavender; commences to bloom in June.

25 c each, \$2.00 dozen

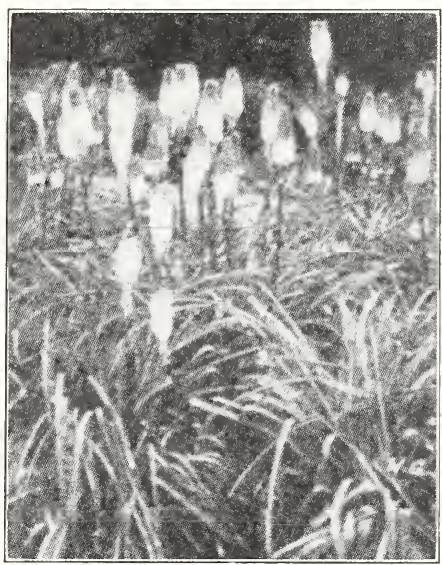

PFITZER'S TRITOMA

Tritoma-RED HOT POKER-This blooms from July until frost time. The flower spikes are bright red cone-like heads that protrude above the drooping green leaves several feet. It is rather unusual and attractive. 2-3 feet.

35c each, $\$ 3.00$ dozen

VERONICA Longifolia Subsessilis (Speedwell). A 2-foot border plant with attractive foliage of distinct character, a roughened bronze green. Flowers are borne abundantly during July and August in long compact spikes. Deep blue.

Incana. Deep blue flowers with silvery foliage. 1 foot. July-August........25c each, \$2.00 dozen

Spicata. 18 inches. June and July. Long spikes of violet-blue flowers..25c each, $\$ 2.00$ dozen

\section{PLANTS}

Vegetable and Annual Flower Plants. Our line complete. List of varieties and prices mailed on request. 


\section{HARDY PERENNIAL ALPINE AND ROCK GARDEN PLANTS}

Alyssum-Saxatile Compactum (Golden Tuft), $25 \mathrm{c}$ each, $\$ 2.00$ dozen

Achillea-Boule Deneige (Ball of Snow), $25 \mathrm{c}$ each, $\$ 2.00$ dozen

Achillea-Millifolium Roseum (Rosy Milfoil), $25 \mathrm{c}$ each, $\$ 2.00$ dozen

Anemone-Hupenhensis, Dwarf, Earliest and Hardiest, Rose Color,

$25 \mathrm{c}$ each, $\$ 2.00$ dozen

Arabis-Alpinus (Rock Cress), White, May and June. . . . . . . . . . .25c each, \$2.00 dozen

Dicentra-Examia, Dwarf, Pink Flowers, Fancy Foliage, Blooms all Summer. .25c each, $\$ 2.00$ dozen

Dianthus-Cæsius, Grandiflorus, Fragrant, Compact, Rose Color.......35c each, \$3.00 dozen

Elymus-Glaucus (Blue Lime Grass), Narrow Blue Foliage, 8 inches......35c each, $\$ 2.50$ dozen

Gypxophilia-Repens (Baby Breath), Trailing, White and Pink Flowers.... .25c each, \$2.00 dozen

Gypsophilia-Paniculata, White Mist Flower. $25 \mathrm{c}$ each, $\$ 2.00$ dozen

Gypsophilia-Bristol Fairy, New Double Baby Breath.............75c each, $\$ 8.00$ dozen

Pentstemon-Gordoni Splendens, Bright Blue, 25 c each. $\$ 2.00$ dozen

Silene-Schafta, Light Blue, $25 \mathrm{c}$ each, $\$ 2.00$ dozen

Sedum-Stonecrop, Sedum Acre (Golden Moss) $25 \mathrm{c}$ each, $\$ 2.00$ dozen

Sarmentosum-Good for Filling Seams between Rocks.............25c each, $\$ 2.00$ dozen

Spectabile-Erect Growing, Rose-Colored Flowers. ..............25c each, \$2.00 dozen

Tunica-Saxifraga (Coat Flower), Dwarf, Fine Foliage Tufts, Pinkish-White Mist Flowers. $25 \mathrm{c}$ each, $\$ 2.00$ dozen

Violas-Jersey Jem (New), Rich Violet, Slightly Perfumed............35c each, $\$ 3.00$ dozen

Veronica-Incana, White Woolly Plant, Blue Flowers............25c each, $\$ 2.00$ dozen

Veronica-Spicata, Long Violet Blue Spikes, $25 \mathrm{c}$ each, $\$ 2.00$ dozen

\section{HOLLAND PEAT MOSS-Large}

Bales............\$4.50 each 5 bales $\$ 20.00$

Majority of plants we list are recommended by F. F. Rockwell in his recent book, Rock Gardens.

\section{GOLD FISH}

4 -inch.............25c each, \$2.50 dozen 10 to 12 inch Breeders............\$3.00 pair

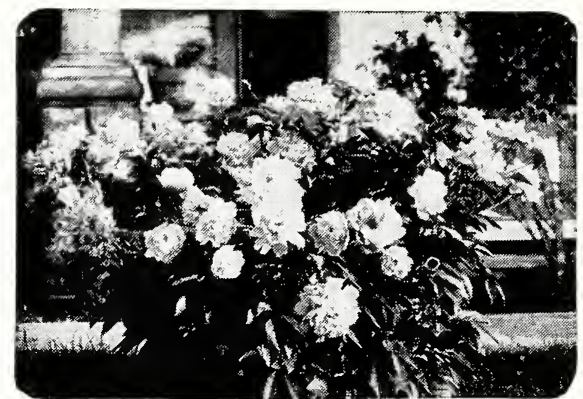

EDULAS SUPERBA-PINK PEONY

\section{PEONIES}

\section{THE GRAND OLD-FASHIONED FLOWERS}

There is no doubt but that the peony is the superior perennial. Those who now know the newer and better varieties or who have seen them in comparison with the older kinds readily admit that there is nothing quite surpassing them in beauty and charm. Of all the perennials they are the most permanent. They are long lived, as you no doubt recall those that were so long in your grandmother's garden. Their ease of culture, hardiness and freedom from disease and insect pests make them rightfully popular. Much has been written and said about the peony and of all that has been printed or heard I have yet to hear an exaggeration.

\section{PLANTING}

It thrives best in deep, rich soil and a sunny exposure. It will grow in partial shade but usually proves a complete failure when planted near the roots of trees. Never plant roots of peonies deep in the soil for they will grow but little and seldom bloom. We never cover the buds or eyes more than three inches as this is sufficient.

\section{WHITE PEONIES}

Baronesse Shroeder-A very delicate flesh pink, fading to white with suggestion of heliotrope and gold. Midseason.

Festiva Maxima-The grandest of the whites. Early. The flowers are extra large, color a pure white save carmine tipped petals........\$.75

Duke of Wellington-A midseason white of unusual vigor, often having several blossoms to each stem.

Mad. de Verneville-Another very desirable white variety, free bloomer and should be in every collection. Early.

\section{SPECIAL OFFER}

12 Peonies, our selection.

3 to 5 eye roots................\$ 3.60 


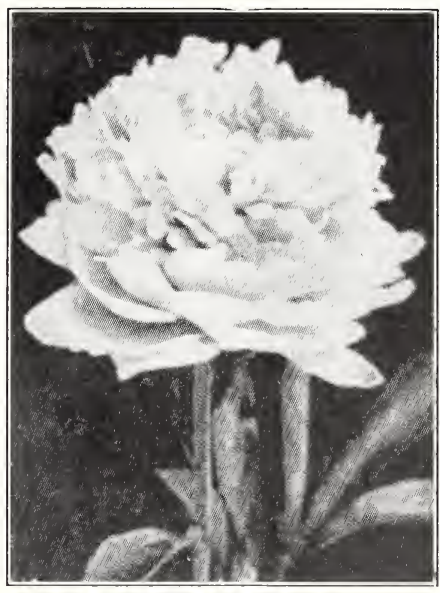

QUEEN VICTORIA (WHITLEY II)

\section{PINK PEONIES}

Asa Gray-A soft, shell pink, mottled and veined rose. Midseason, and plant vigorous. Supply limited.

Alexandre Dumas-A strong midseason, freegrowing pink of decp and pleasing color.
Edulis Superba-Another deep rose of different season, valued for its fragrance and freedom with which it flowers. Early.

La Tulipe-Of late season, compact blossom, white with streaks of red and pink on many petals. Resembles the tulip somewhat.

Livingstone-Late; clear pink. Very fine.

Venus-Pale hydrangea-pink, large, compact crown. Midseason.

PEONIES, SPECIAL

Red, White, Pink.............. 3 for $\$ 1.00$

\section{RED PEONIES}

Francois Ortegat-A midseason to late variety, being very dark rose color with yellow stamens; flowers large on strong stems. Extra good.

Delachei-A late, deep, rich red, of unusual color. An old favorite and esteemed by everyone who knows it.

Felix Crousse-A midseason variety of the most pleasing velvety-red color, fading to lighter shades as the blossom falls.

Officinalis Rubra-Rich, dark crimson. This is the old-fashioned extra early red and still very scarce.

\section{CLIMBING AND CLINGING VINES}

LEND CHARM TO ANY HOME

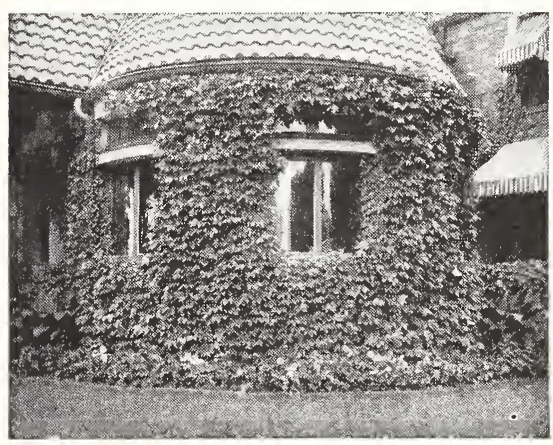

BOSTON IVY

With their variance in color, their bcauty of foliage and blossom, their grace wherever used, these vines frequently provide the finishing touches of any planting. Some adherc to the masonry, some must be trained through lattice or trellis and others, with their tendrils, will cling tenaciously.

\section{AMPELOPSIS}

A. Englemannii-I M P R O V E D VIRGINIA CREEPER - Valuable for covering old fences, etc. Leaves red in fall................ . . . . .
A. Veitchii-BOSTON IVY-The beautiful selfclinging vine that is used to cover walls of stone or brick. Leaves form a dense sheet of green as they overlap each other; a little difficult to start, but when once established requires no further care. Foliage changes to a crimson-scarlet in the fall.

$\$ .50$ and $\$ .75$

\section{CLEMATIS HYBRIDS}

These popular vines are known and planted everywhere for the profusion of beautiful, large flowers they produce. Not as hardy or healthy as C. Paniculata, but when once established are worthy of all the extra care in getting them started.

C. Jackmanii. Large purple......... .\$ .75

C. Andre. Large red............ .75

C. Henryi. Large white............ . .75

C. Paniculata. The small, white, sweet-scented varieties that are beautiful both in foliage and blossom..................... .50

Hedera Helix-ENGLISH IVY-An excellent evergreen vine with glossy green leaves, unexcelled for covering walls in shady or cool places. May be used for porch or window boxes for all year effect. When closely sheared makes a good edging for walks or borders, being hardy and evergreen.

In Pots............. $\$ .25, \$ .35$ and $\$ .50$ 


\section{EUONYMUS-BITTERSWEET}

E. Radicans-A slow-growing vine that adheres to the masonry and remains deep green all winter.

E. Radicans Vegetus-EVERGREEN BITTERSWEET-Another evergreen clinging vine of more robust habit, perfectly hardy and especially valued because of the profusion of red berries that hang on for several weeks............... .75

Bittersweet (Native) Celastrus Scandens-This is the familiar native vine that is so unusually attractive of berry in the fall and early winter. Very vigorous and healthy ..........\$ .50

\section{HONEYSUCKLE-LONICERA}

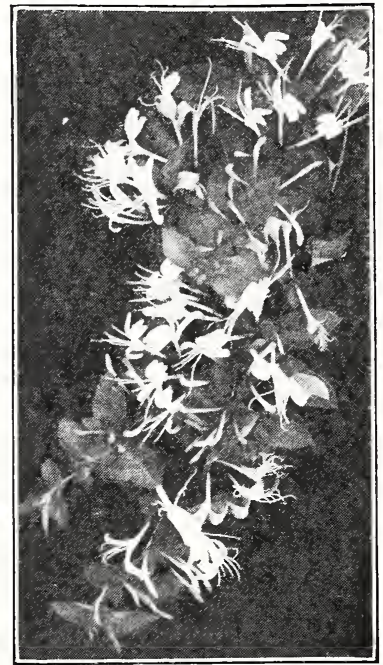

HONEYSUCKLE, HALL'S JAPAN

HONEYSUCKLE. Hall's-This is the popular evergrcen honeysuckle used by everyone for screen, beauty and fragrance. Blooms continuously and is easy to establish. It is also evergreen . . . .\$ .50

HONEYSUCKLE. Coral-Flowers bright scarlet, little fragrance. Strong grower and hardy.

$\$ .50$
KUDZU VINE. Pueraria Thunbergiana-We have so many calls for a very rapid growing, twining vine to cover unsightly objects, for quick effect where other vines are too slow, that we list this vine. It belongs to the pea family, has insignificant flowers, but the foliage is very large, of attractive green color, and specimens have frequently grown thirty feet in a season after established . . . . .\$ $\quad .50$

LYCIUM (Matrimony Vine). Chinense. Chinese Matrimony Vine. Ornamental, shrubby climber. Small purplish flowers in summer, followed by scarlet berries until late in winter.

2 years, No. $1 \ldots \ldots \ldots \ldots \ldots \ldots \ldots \ldots$......... each

POLYGONUM. Auberti-China Fleecevine. Lace Vine. One of the most desirable flowering climbers. The plant is of strong, vigorous growth, attaining a height of 25 feet or more, producing through the summer and fall great foamy sprays of creamy white flowers.

2 years, No. 1..............\$1.00 each

TRUMPET VINE. Radicans. Bignonia-A robust, woody vine, twining tightly with numerous tendrils along its stems. Leaves are dark green. Very desirable for covering summer houses, arbors, trees or rustic bridges. Scarlet flowers.... .\$ .75

WISTERIA. A rampant, clinging vine that has the robust vigor of a wild grape and matchless beauty of a rare exotic. Colors both white and purple. \$.75. Grafted, $\$ 1.00$.

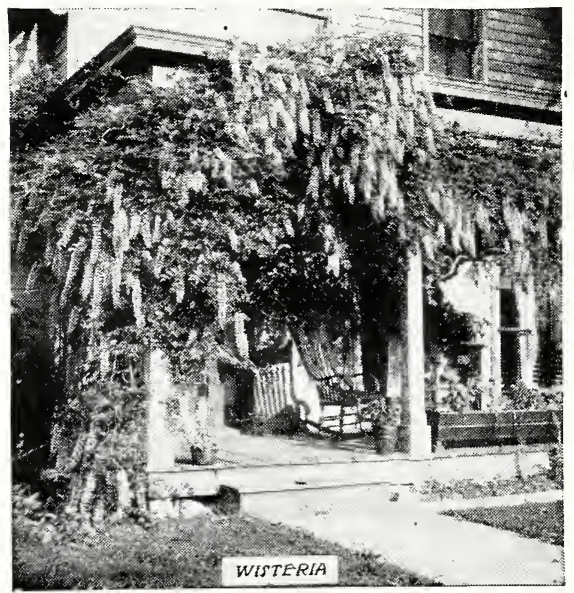

\section{HARDY FRUITS FOR THE ORCHARD AND HOME GARDEN}

\section{APPLES YIELD PROFITABLE RETURNS}

\section{EARLY APPLES}

Early Harvest-Pale yellow, sub-acid, regular bearer and is the most popular of the old general purpose varieties.

Early Transparent-Very early bearer, productive; valuable for either home or market. Blights on rich soil, however. Waxy yellow, tart, excellent.

\section{FALL APPLES}

Grimes Golden-No orchard complete without it. Yellow, best quality and productive. For home or market for this season there is nothing better.

Wealthy-Large, shaded to dark red, quality good, tender and productive. Early to bear and exceedingly satisfactory. 


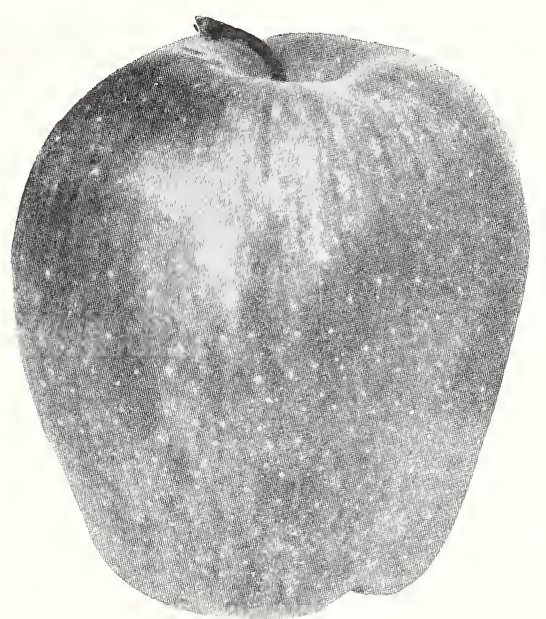

DELICIOUS APPLE

\section{WINTER APPLES}

Delicious-Red, large and uniform in size, distinct because of five lobes on blossom end. Variety new, very popular and no orchard should be without it. Quality unexcelled. A very early and heavy bearer, good for market and home.

Black Twig-A seedling of Winesap, larger, splashed with red, sub-acid and very productive. We can especially recommend this for Virginia. Valuable for home or market. Plant it.

Stayman Winesap-Dark, rich red, indistinctly striped; larger than old Winesap. Tree productive and a drought resister.

Winesap-Medium size, dark red, productive variety, excellent quality, crisp and juicy; sub-acid. The most extensively grown, the most abundant bearer, with more good qualities in its favor than anything we have to offer for Virginia.

York Imperial-A late keeping commercial variety, shaded red on yellowish skin, flesh firm and tree healthy. Regular and heavy bearer. Plant for profit or for home.

\section{CRAB APPLES}

Hyslop-Large, dark. Tree vigorous and productive, each.................... $\quad .75$

Whitney-This is a really edible crab; late, and good for jelly or use from hand, each...... .75

\section{APPLE TREES}

4 to 6 feet. ..................... .50

4 to 5 feet, per $100 \ldots \ldots \ldots \ldots \ldots \ldots \ldots$

Transparent

Early Harvest

Stayman Winesap

Delicious

Albemarle Pippin

Winesap

Grimes Golden

York

We do not guarantee our trees to be true to name. We do everything in our power to send our stock true to name but, should any prove otherwise, we will not be responsible for damage exceeding original cost of trees.
PEACHES

\section{ARE PROFITABLE AND POPULAR}

\section{EARLY RIPENING}

Greensboro-(Free) The very best extra early commercial sort. Hardy and productive, fruit large and tree healthy. Color, white with crimson cheek. July 1st.

\section{SECOND RIPENING}

Belle Georgia-(Free) White with decided blush; excellent quality; heavy and regular bearer. In this variety we have the best white-fleshed peach for home or market. August 5th.

Carmen-(Free) White with red blush. Carmen is extra hardy, bears every year and when it fails all else fails, too. Tree a robust grower and produces heavily. Next to Elberta, Carmen should be considered. We are partial to it. July 20th.

Champion-(Free) White fleshed with attractive red cheek, juicy, good quality and dependable. August ripening.

Elberta-(Free) Beautiful yellow, large and shaded with deep red. Elberta has been the peach for years and is just as good to-day. The fact that more than eighty per cent. of commercial plantings are of this variety speaks well enough for it. August 15 th.

J. H. Hale-(Free) Yellow, almost covered with red; more highly colored than Elberta; flesh firm, melting and of best quality. Ripens August 10th15 th.

\section{LATE RIPENING}

Heath-(Cling) White, tinged next to sun. A large, firm, juicy peach of most pleasing flavor. Well known. October 1st.

\section{We prefer not to fill orders for less amount} than $\$ 1.00$.

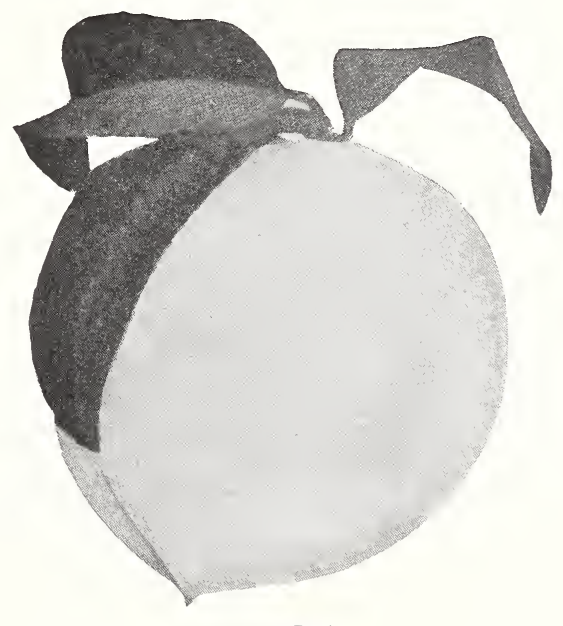

ELBERTA 


\section{PEACH TREES}

3 feet. .................... .30

$\begin{array}{ll}\text { Carmen } & \text { Hale } \\ \text { Belle Georgia } & \text { Champion } \\ \text { Elberta } & \text { Hiley } \\ & \text { Heath Cling }\end{array}$

\section{SPECIAL LEADING VARIETY PEACH TREES}

3 feet, per hundred.............\$12.50

\section{VIRGINIA DEPARTMENT OF AGRICULTURE AND IMMIGRATION}

Official Tag No. 1246

Richmond, Va., August 23, 1929

This is to certify that, acting under authority of law, C. R. Willey inspected the nursery premises of

Hedge Lawn Nursery, at Roanoke, Va., on the 19th day of July, 1929, and that the nursery stock on said premises was found to be apparently free from dangerously injurious insects and plant diseases.

This certificate can only be used on the aforesaid stock and such other stock as may be purchased under the official tag of the Department of Agriculture of the State of Virginia.

\section{G. T. FRENCH,}

State Entomologist and Plant Pathologist This tag expires August 31, 1930.

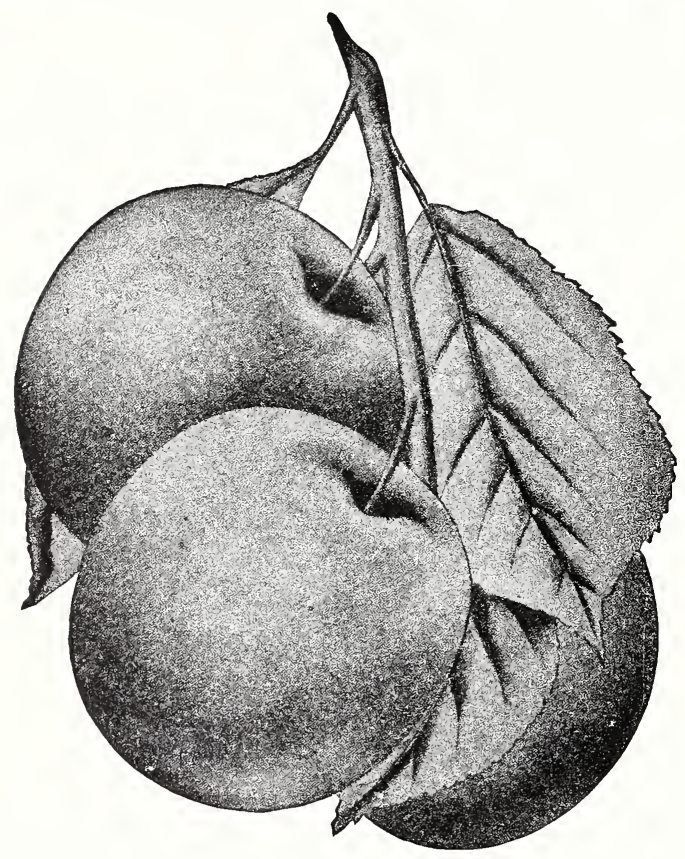

ABUNDANCE PLUM

THE PLUM

FOR MARKET AND HOME USE

PLUM TREES

4 to 5 feet. . . . . . . . . . . . $\$$

Burbank

Black Beauty

Wickson

Abundance

Shropshire Damson Red June

PEARS

THE DELIGHTFUL EATING FRUIT

\section{PEAR TREES}

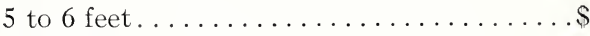
.75

Keiffer Clapp's Favorite Bartlett

Dutchess Seckel Pineapple

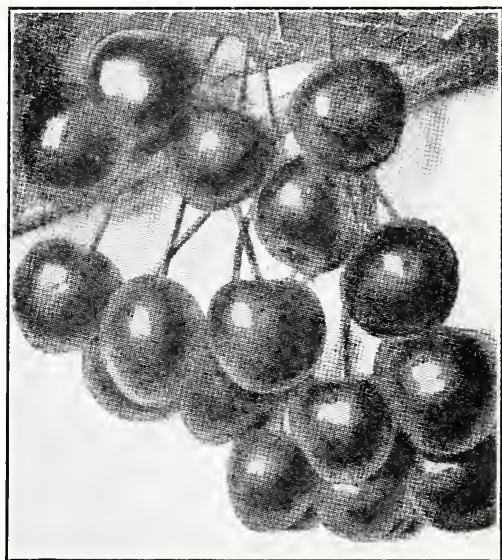

THE CHERRY

HEARTS AND BIGGAREAUS

CHERRY TREES

4 to 5 feet, each. $\$ \quad .75$

Tartarian

Napoleon

Windsor

Governor Wood

Yellow Spanish

SOUR

$\begin{array}{ll}\text { English Morello } & \text { Early Richmond } \\ \text { May Duke } & \text { Montmorency }\end{array}$

THE QUINCE

The Quince-Luxuriates in good, deep ground and on such will quickly yield an abundance of fruit just the best to preserve or for jelly. We have tried all the standard kinds, but the Orange has been by far the best for us.

4 feet. . . . . . . . . . . . . . . . . . 


\section{SMALL FRUITS}

\section{CURRANTS}

THE BOUNTIFUL PRODUCER

The white varieties have proven worthless in this climate.

Currants, dozen

\section{GRAPES}

The Universal Fruit

BLACK GRAPES

WHITE GRAPES

RED GRAPES

2 years old, each............... .35

3 for . . . . . . . . . . . . . . .

Per $100 \ldots \ldots \ldots \ldots \ldots \ldots \ldots \ldots \ldots \ldots$. . . . . . . . . . . . .

\section{GOOSEBERRIES}

Houghton.
GRAPE VINES

\section{STRAWBERRIES}

\section{ALWAYS PRODUCTIVE-ALWAYS} IN DEMAND

Aroma Strawberries

Per $100, \$ 1.00$; per $1,000, \$ 7.00$

Premier Strawberries

Per $100, \$ 1.00$; per $1,000, \$ 7.00$

Lupton Late Strawberries

Per $100, \$ 1.00$; per $1,000, \$ 7.00$

Progressive Ever-bearing

Per $100, \$ 2.00$; per $1,000, \$ 15.00$

Write for special quantity Fruit Tree prices for Orchard Planting. All trees and vines sold by us are well rooted.

\section{BLACKBERRIES}

PROLIFIC AND EASY TO GROW

Blackberries, per 100

$\$ 2.50$

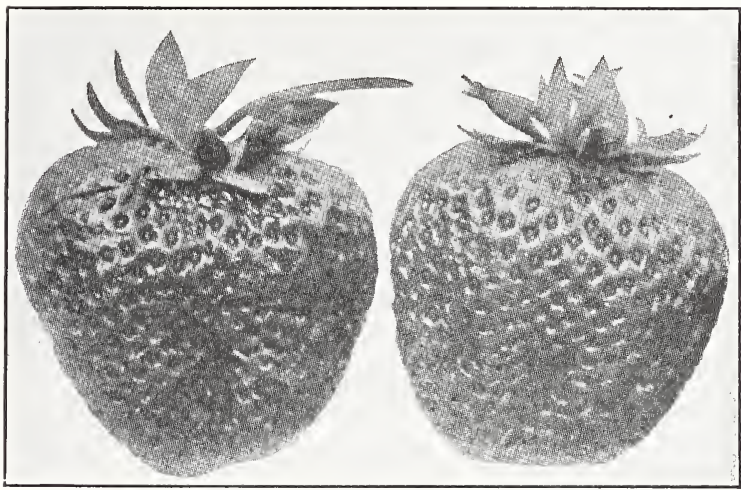

RASPBERRIES

RED RASPBERRIES

BLACKCAP RASPBERRIES

Raspberries, per 100.............\$ 3.00

\section{VEGETABLE AND FLOWER PLANTS}

Our list mailed on request. We can supply plants from pots or beds.

AROMA

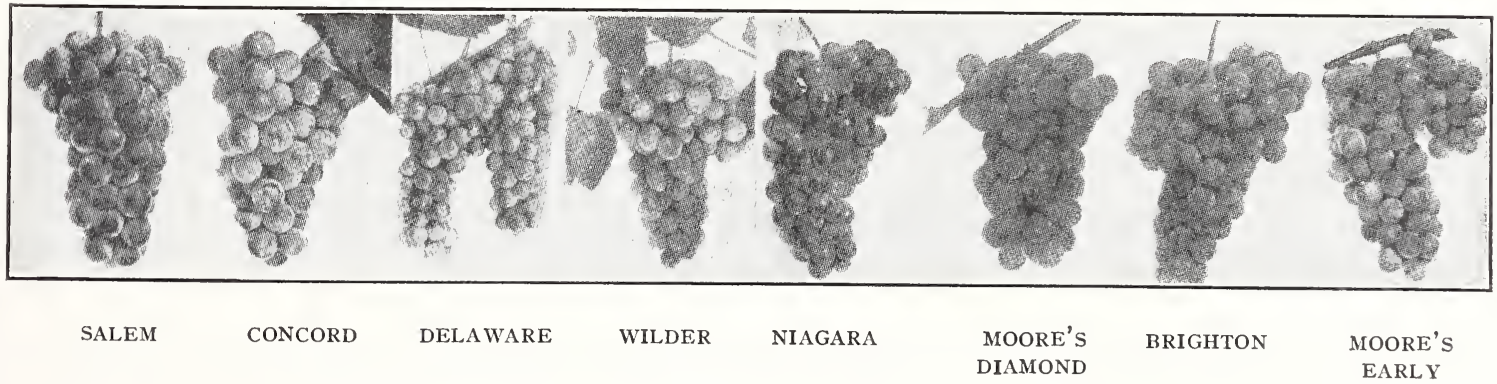




\section{Seventeen Unusual Values in Nursery Stock}

HERE IS A REAL OPPORTUNITY. These seventeen collections of nursery stock are made up of choice trees and plants backed by the reputation and reliability of Hedge Lawn Nurseries. We realize, from the unusual number of calls we have for assistance in choosing varieties, that a large per cent. of the purchasers of nursery stock do not know what selection to make. These collections are carefully chosen with the idea of filling exactly the needs of the average planter. You may purchase any one with the assurance of getting the best in variety and season. We, also, will send pruning and planting instructions with each order. TERMS: Remittance must be sent with order. We prefer that you use enclosed order blank only. All shipments, F. O. B. Roanoke. ORDER EARLY before assortments are broken.

\section{SPECIAL OFFER No. 1}

This collection of 10 Apple Trees is just the one for the small garden or suburban lot. It will contain three summer, two fall and five winter varieties. Will cover the fruiting season like a "blanket." $4 \frac{1}{2}$ to 6 feet size. Regular price, $\$ 5.00$. Special. . . . . . . . . . . . . . . . . \$ 4.50

\section{SPECIAL OFFER No. 2}

If you want Peaches from the last of June to October, we will give you in this assortment of $\mathbf{1 0}$ excellent peach trees; varieties that will keep you in fruit all summer. They will be selected in about this proportion-four white, five yellow free, and one clingstone variety. 3 to 4 feet size. Regular price, $\$ 5.00$

Special

SPECIAL OFFER No. 3

\section{Fruits in Variety}

2 Apple

4 Peach

1 Cherry

This will give you fruit from May to October and longer. If your space needs 10 trees this is our prize collection. Number one size. Regular price, $\$ 7.30$

Special.

$\$ 6.50$

\section{SPECIAL OFFER No. 4}

Some folks prefer the smaller trees. Same as above in assortment, but in the $3 \frac{1}{2}$ to 5 feet size. Regular price, $\$ 6.30$.

Special.

$\$ 5.75$

\section{SPECIAL OFFER No. 5}

Small Fruits-Here is a collection that surely is a fine one for any home owner's lot. Grapes to trail along the fence, the currants and gooseberries to grow along the garden walk, and postage paid, too! 6 Assorted Grapes $\quad 25$ Red Raspberries No. 1 4 Choice Gooseberries 25 Black Raspberries 6 Currants

Regular price, $\$ 4.95$.

Special.

\section{SPECIAL OFFER No. 6}

8 Grapes-Should be planted 6 to 8 feet apart. Here is a dandy collection, in all colors, early and late, and at a reasonable price, too, for heavy vines. Regular price, $\$ 2.80$.

Special.

\section{SPECIAL OFFER No. 7}

Or if your space permits, we will increase the number to 25 and make a selection that will cover the entire fruiting season and send them postage paid. Regular price, $\$ 6.25$.

Special. . . . . . . . . . . . . . . . . . . . . \$ 4.50

\section{SPECIAL OFFER No. 8}

Every Garden Needs These Plants-Just fill in the order number and the mail man will deliver:

100 Asparagus 10 Rhubarb

Regular price, $\$ 3.50$.

Special.......................\$\$ 3.00

\section{SPECIAL OFFER No. 9}

Shade Trees-Here are six assorted shade trees, three rapid-growing and three of the hardwood type. These are our best.

2 Soft Maple, 6 to 8 feet 1 American Ash,

2 Sugar Maple, 6 to 8 feet 6 to 8 feet

Regular price, $\$ 6.50$ 1 Elm, 6 to 8 feet

Special

\section{SPECIAL OFFER No. 10}

This collection of Blooming Shrubs is carefully assorted for use along the foundation of your home. Blossoms and berries from April to April, varying in height from 2 to 5 feet.

4 Spirea Van Houttei for taller growth.

2 Spirea Cullosa for intermediate growth.

2 Spirea Thumbergii for smaller growth.

4 Japan Barberry for border. Best sizes.

Regular price, $\$ 6.00$.

Special.........................

$\$ 5.00$

\section{SPECIAL OFFER No. 11}

Another Dozen Shrubs for medium height that mature at 3 to 6 feet. Note the flowering period, too. You will make no mistake in trying this one for a group planting on your lawn.

3 Cullosa Spirea. May.

4 Spirea Van Houttei. May.

2 Weigela. May.

1 Hydrangea. August.

1 Snowberry. Fall.

1 Coral Berry. June.

Regular price, $\$ 6.00$.

Special. . . . . . . . . . . . . . . . . . . . .\$ 5.00 


\section{SPECIAL OFFER No. 12}

Still another Collection of Blooming Shrubs, designed for a background or for screening low, unsightly objects. This embraces the very best plants of their respective blooming season. U1timate hcight, 6 to 12 feet.

3 Bush Honeysuckle. Tall and spreading.

3 Mock Orange. Tall.

2 Deutzia. Erect.

1 Double Althea. Tall.

3 Spirea Van Houttei. Intermediate.

Regular price, $\$ 6.00$

Special.

\section{SPECIAL OFFER No. 13}

10 Evergreens for $\$ 15.00$

2 Chinese Arbor Vitae, 2 feet.

4 American Arbor Vitae, 2 feet.

2 Green Spruce, 2 feet.

2 Globe Arbor Vitae.

A Twenty-Dollar Collection for.

$\$ 15.00$

This assortment will make you a nice foundation planting

\section{SPECIAL OFFER No. 14}

15 Choice Evergreens for $\$ 20.00$

2 Norway Spruce, 18 to 24 in.

3 American Arbor Vitae, 18 to 24 in.

4 Globe Arbor Vitae, 15 to 18 in.

4 Chinese Arbor Vitae, 18 to 24 in

2 Tom Thumb Arbor Vitae, 15 to 18 in.

The above special collection will make an attractive foundation planting and add many dollars to the value of your home.

\section{SPECIAL OFFER No. 15 \\ 12 Perennials}

The Old-Fashioned Perennial Garden or Border of your mother or grandmother can be started with this fine collection of perennials and biennials. All the summer months will be brightened with flowers of this collection.

Special

\section{SPECIAL OFFER No. 16}

24 plants, as above, regular price, $\$ 4.00$.

Special .....................\$ 3.50

\section{SPECIAL OFFER No. 17}

50 plants, as above, regular price, $\$ 10.00$.

Special

\section{SPECIAL}

Following Are a Few of Our Specialties:

California Privet Hedge, 18 to 24 in., branched, $\$ 3.50$ per Hundred

Lombardy Poplar, 8 feet, well branched, each ................... .50 Grapes, Large, 3-yr., bearing size . 3 for $\$ 1.00$ Apple Trees, 4 feet...... $\$ 18.00$ per Hundred Peach Trees, 3 feet. . . . \$12.50 per Hundred
NON-WARRANTY - We aim to keep our stock pure and true to name, but in the event any Nursery Stock, Seeds or Plants sold by us should prove untrue to name and the purchaser should be thereby damaged, we hereby agree, on proper proof, to replace such stock as may prove untrue to the name under which it is sold or to refund the purchase price. Refunding or replacing to be at our option. Except for such liability, and in respect to all stock sold by us, we give no warranty, either expressed or implied, as to description, quality, growth, productiveness, or any other matter, and all stock, plants and seeds are sold and received with the agreement between the purchaser and ourselves that we shall never be liable for any amount greater than set out herein.

A Table Showing the Number of Trees or Plants to the Acre by the Square System.

\begin{tabular}{|c|c|c|c|c|c|c|}
\hline \multicolumn{7}{|c|}{ Distance } \\
\hline & oot & & & way & & $\$ 3,560$ \\
\hline & feet & & & & & 10,890 \\
\hline & & “ & “ & “" & $\ldots \ldots \ldots \ldots$ & 4,840 \\
\hline 4 & “ & “" & “" & “، & $\ldots \ldots \ldots$ & 2,722 \\
\hline 5 & “" & “ & “" & “ & $\ldots \ldots \ldots \ldots \ldots \ldots \ldots$ & 1,745 \\
\hline 6 & “" & “" & “" & “" & $\ldots \ldots \ldots \ldots \ldots \ldots \ldots$ & 1,210 \\
\hline 7 & “" & “ & “" & “ & $\ldots \ldots \ldots \ldots \ldots \ldots \ldots$ & 888 \\
\hline 8 & “" & “" & “" & “" & $\ldots \ldots \ldots \ldots \ldots \ldots \ldots$ & \\
\hline 9 & “" & “" & “" & “" & $\ldots \ldots \ldots \ldots \ldots \ldots \ldots$ & \\
\hline 10 & “" & “ & “" & “ & $\ldots \ldots \ldots \ldots \ldots \ldots \ldots$ & \\
\hline 11 & “" & “" & “" & “" & $\ldots \ldots \ldots \ldots \ldots \ldots \ldots$ & 00 \\
\hline 12 & “ & “" & “" & “" & $\ldots \ldots \ldots \ldots \ldots \ldots \ldots$ & \\
\hline 13 & “" & “" & “" & “" & $\ldots \ldots \ldots \ldots \ldots \ldots \ldots$ & \\
\hline 14 & “ & “ & “" & “ & $\ldots \ldots \ldots \ldots \ldots \ldots \ldots$ & 22 \\
\hline 15 & " & “" & “" & “" & $\ldots \ldots \ldots \ldots \ldots \ldots \ldots$ & \\
\hline 16 & “ & “" & “" & “" & $\ldots \ldots \ldots \ldots \ldots \ldots \ldots$ & \\
\hline 17 & “ & “ & “" & “" & $\ldots \ldots \ldots \ldots \ldots \ldots \ldots$ & \\
\hline 18 & “" & “" & "“ & " & $\ldots \ldots \ldots \ldots \ldots \ldots \ldots$ & \\
\hline 19 & $"$ & " & " & “" & $\cdots \ldots \ldots \ldots \ldots \ldots \ldots$ & \\
\hline 20 & " & ". & " & $"$ & $\cdots \ldots \ldots \ldots \ldots$ & \\
\hline 15 & “" & ، & “" & “، & $\cdots \ldots \ldots \ldots \ldots$ & \\
\hline & ، & ، & ، & ، & . & \\
\hline 40 & “، & “" & ، & ، & $\cdots$ & \\
\hline
\end{tabular}

\section{DISTANCES FOR PLANTING}

Standard Apples........40 feet apart each way Standard Pears and Strong-

Growing Cherries......20 feet apart each way

Duke and Morello Cherries. 18 feet apart each way

Standard Plums, Peaches, Apricots and

Nectarines.......16 to 18 feet apart each way

Dwarf Pears, Dwarf Apples and

Quinces.........10 to 12 feet apart each way

Grapes............ Rows of 10 to 16 feet apart, 7 to 16 feet in rows

Currants and Gooseberries.........4 feet apart

Raspberries and Blackberries. . .........3 to 4 feet by 5 to 7 feet

Strawberries, for field culture.... 1 by 3 to $31 / 2$ feet Strawberries, for garden culture...1 to 2 feet apart Asparagus, in beds. ........... by $11 / 2$ feet Asparagus, in fields.............1 by 3 feet

Rule-Multiply the distance in feet between the rows by the distance the plants are apart in the rows and the product will be the number of square feet for each plant or hill; which divided into the number of feet in an acre $(43,560)$, will give the number of trees to an acre. 


\section{GARDEN WARE}

A superior furniture for garden and interior decoration. White flint sand, mixed with cement, moulded into artistic shapes and properly seasoned. The result is a garden furniture of fine appearance, equal in hardness and wearing quality to natural stone. It is both weather-proof and timeproof. It keeps for a lifetime the delicate tracery as well as the sharp detail of its design. It is finished in gray to resemble granite, or in white to resemble marble and the resemblance is strikingly good. This ware has the advantage of being much less expensive than either of these stones.

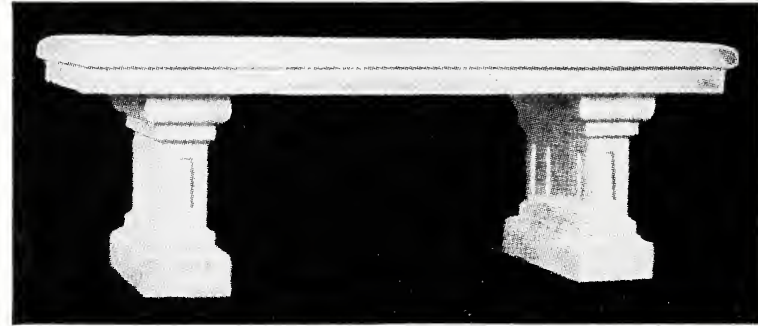

LAWN SEAT

50 inches long and 20 inches wide. Legs are 15 inches wide and 14 inches high.

No. 7-Natural Granite White. $\$ 10.00$

No. 8-Cement Gray......... 8.00

\section{LAWN SEAT}

Thickness, 3 inches; width, 20 inches; and length, 5 feet.

No. 1-Natural Granite White.........\$12.50

No. 2-CementGray............... 10.00
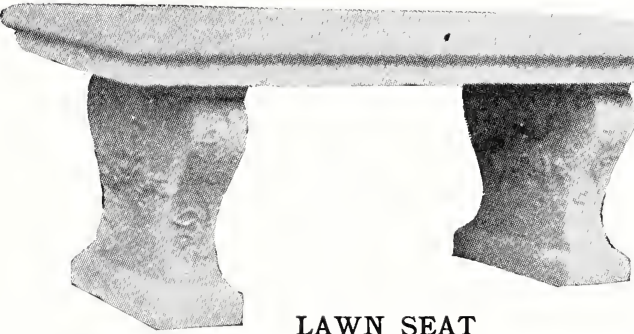

LAWN SEAT

50 inches long and 20 inches wide. Legs are 16 inches high and 14 inches wide.

No. 3-Natural Granite White. . . . . . . . \$10.00

No. 4-Cement Gray ... . . . . . . . . . . . 8.00

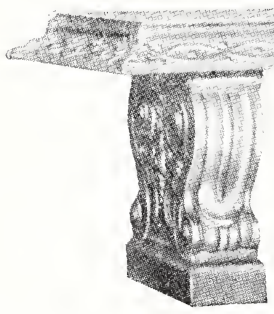

\section{CURVED LAWN SEAT}

Thickness, $3 \mathrm{I} / 4$ inches; width, 20 inches, and length, outside curve, 5 feet 4 inches. Length, inside curve. 4 feet 1 inch.

No. 5-Natural Granite

White..........\$18.50 No. 6-Cement Gray.... 15.00

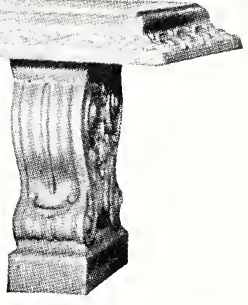

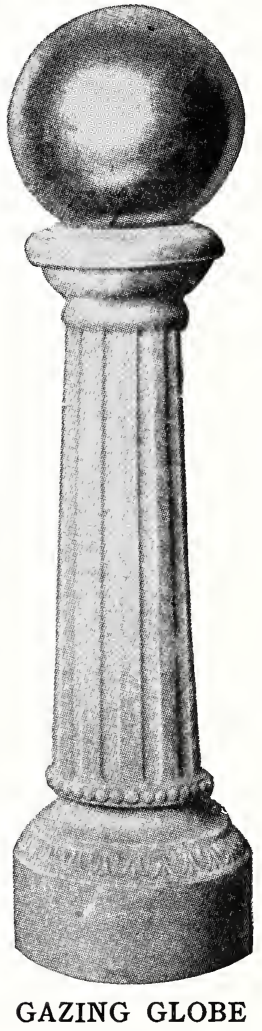

Pedestal-H e i g h t , 40 inches; diameter, at top, $10 \mathrm{r} / 2$ inches; diameter, at base, $12 \frac{1}{2}$ inches.

Globe-12 inches.

No. 9-Natural Granite

White.........\$25.00 No. 10-Cement Gray. 20.00 


\section{SUN DIAL}

Mounted on Pedestal shown on preceding page-Dial, copper; size, 12 inches.

No. 11-Natural Granite White. . \$20.00

No. 11 $1 / 2$-Cement Gray........ 15.00

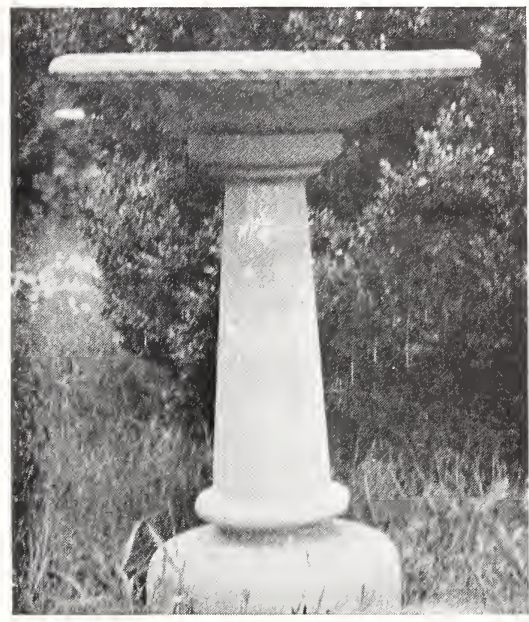

BIRD BATH

Bowl diameter, 23 inches. Pedestal $28 \mathrm{1} / 2$ inches. Diameter, at base, 14 inches.

No. 12 -Natural Granite White. . . . . . \$10.00 No. 13-Cement Gray.............. 8.00

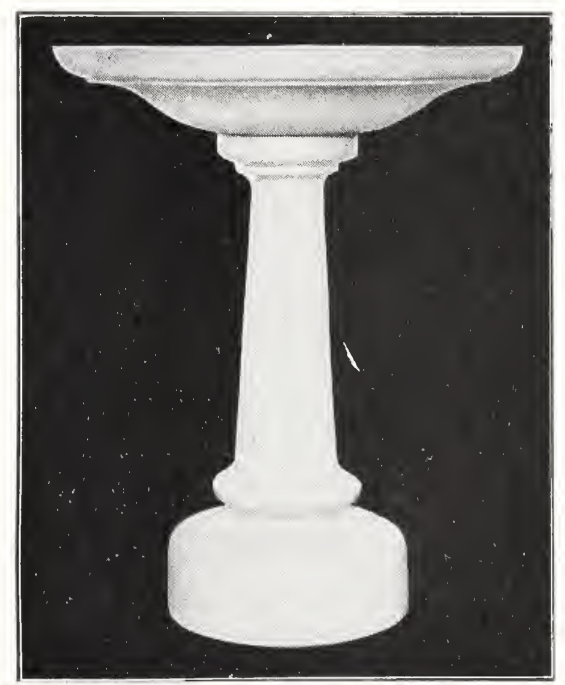

BIRD BATH

Bowl height, 6 inches. Diameter of bowl, at top, 27 inches. Diameter of bowl, at bottom, 8 inches. Pedestal, 281/2 inches. Diameter, at base, 14 inches.

No. 14-Natural Granite White........ \$15.00 No. 15-Cement Gray .............. 12.50

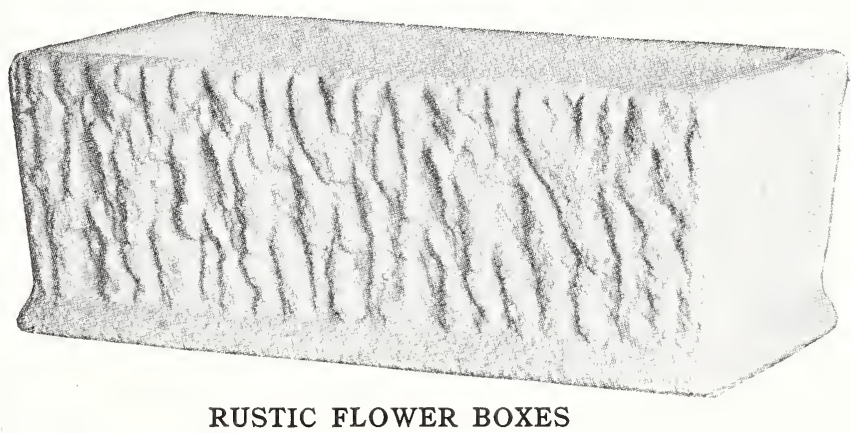

Height, 9 inches; width, 12 inches; and length, 36 inches. No. 16-Natural Granite White. . . . . . . . . . \$ 5.00 No. 17-Cement Gray .................. 3.50 No. 18-Natural Granite White.............. 3.00 Same as above in 24-inch length

2.50

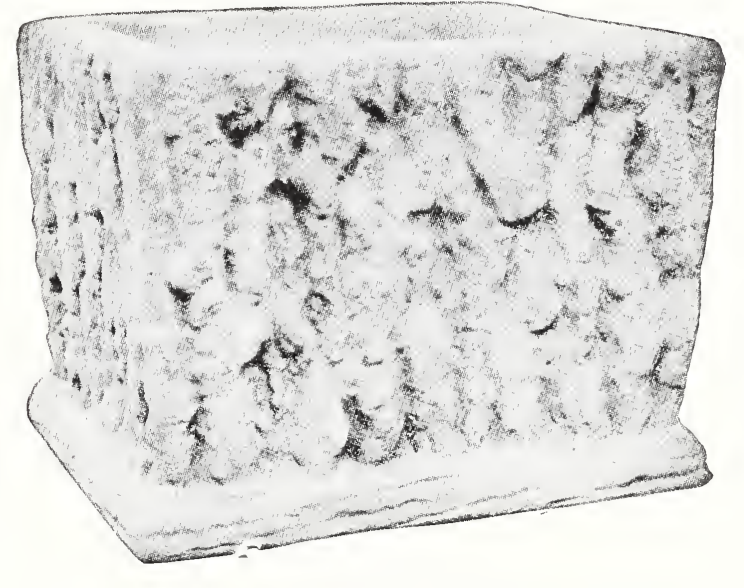

RUSTIC FLOWER BOXES

No. 20-Natural Granite White... . . . .\$2.00

No. 21-Cement Gray ............... 1.50 $12 \times 12$ inches

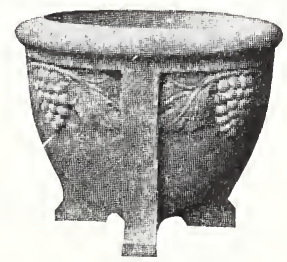

JARDINIERE

Large size, height, 16 inches; diameter, at top, 20 inches. Spread of feet, at bottom, 14 inches. Used for Evergreens, Flowers, etc.

No. 22-Natural Granite White........\$6.00 No. 23-Cement Gray.............. 5.00

Plants will require very little watering in these containers. 


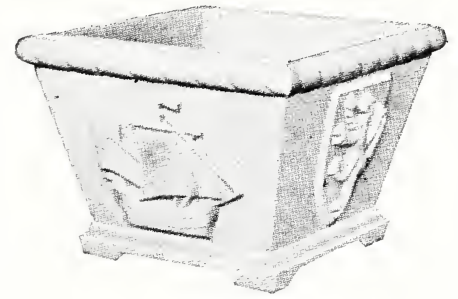

NORMAN BOX

Height, 10 inches. Diameter, at top, 14 inches; at bottom. 12 inches.

No.' 24 -Natural Granite White. . . . . . \$ 3.00

No.'25-Cement Gray.............. 2.50

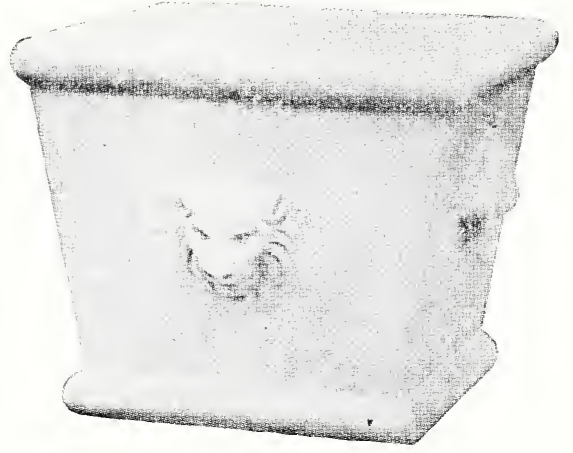

LION HEAD

Height, $13 \mathrm{r} / 2$ inches. Dimensions, at top, 16 inches. Dimensions, at bottom, 12 inches.

No. 26-Natural Granite White........\$5.00

No. 27-Cement Gray................. 4.00

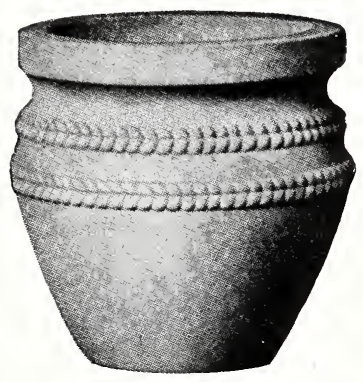

ARCADY WATER JAR

Height, 18 inches. Diameter, at top, 17 inches. Diameter, at bottom, $10 \mathrm{r} / 2$ inches.

No. 28-Natural Granite White........ \$ 8.00

No.!29-Cement Gray............. 6.00

We prefer not to fill orders for less amount than $\$ 1.00$.

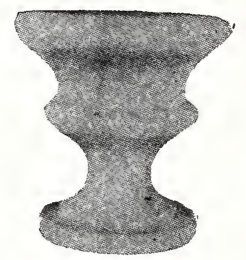

\section{VASE MOLD}

Height, 10 inches; top, $91 / 2$ inches; base, 10 inches. This vase is intended for individual house plants.

No. 30-Natural Granite White... . . . . . \$ 1.50

No. 31 -Cement Gray................. 1.00

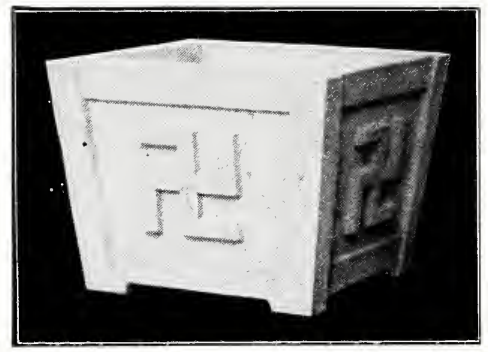

\section{MISSION BOX}

Mission Box-Height of box, $12 \frac{1}{2}$ inches, Dimensions, at top, 17 inches square; at bottom. 14 inches square.

Our most popular Jardiniere, for evergreens, etc.

Will add beauty to any home.

No. 32-Natural Granite White. . . . . . . \$ 4.50

No. 33-Cement Gray ............... 3.50

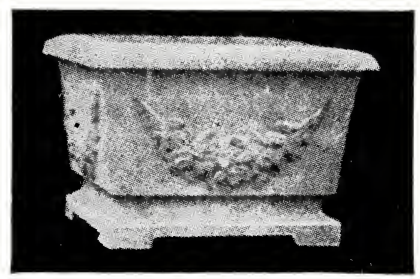

\section{SCULPTURE BOX}

Height, 11 inches; top $16 \times 16$ inches; base, $13 \times 13$ inches.

No. 34-Natural Granite White. . . . . . . . \$ 6.00

No. 35-Cement Gray................ 4.50

The material of which these containers is made retains moisture, thereby requiring little water.

If shipment is wanted by parcel post, be sure to include in your remittance sufficient to cover postage charges. 


\section{TERRA COTTA WARE}

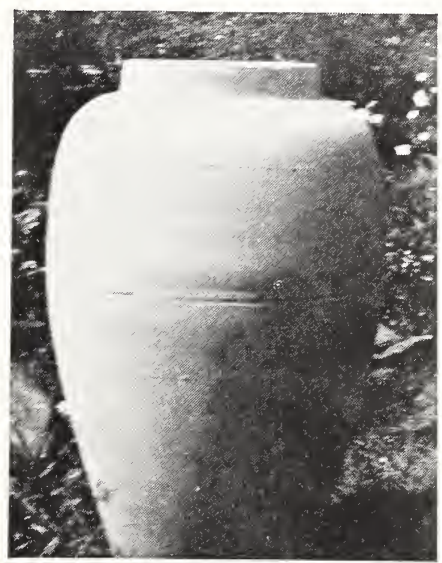

OIL JAR

Height, 30 inches.

No. 36-Red Terra Cotta...

No. 361/2-Red Clay, 17 -inch .

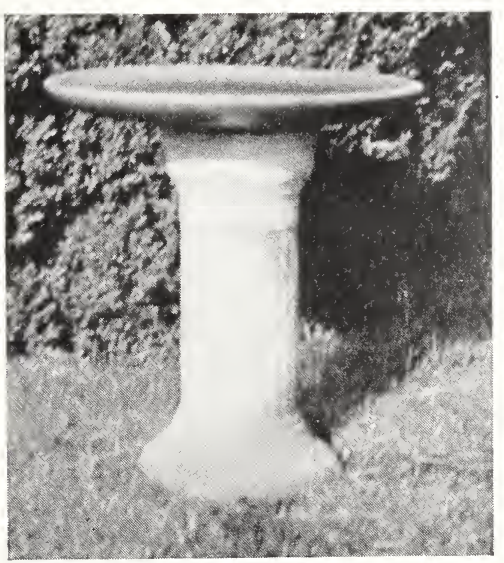

BIRD BATH

Diameter of bowl, 25 inches. Height of pedestal, 24 inches.

No. 37-Gray Terra Cotta............. \$10.00

Bowls Separate............. 5.00

WE CRATE AND SHIP THIS GARDEN WARE

To all parts of the United States. We make no charge for crating.

All Sold F. O. B. Roanoke, Virginia

$\$ 12.50$

5.00

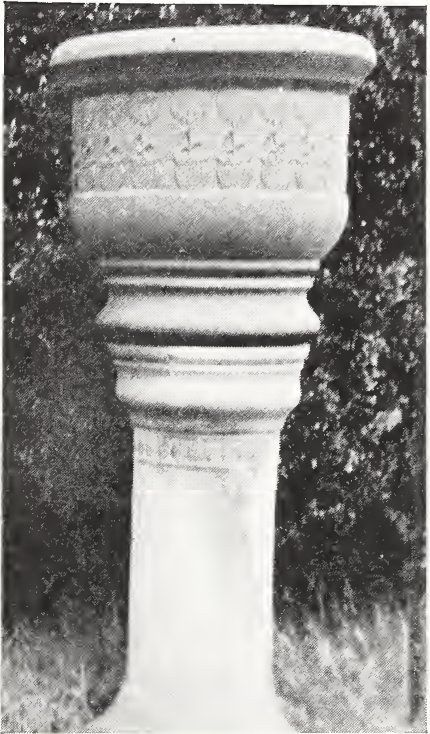

No. 38-Complete

$\$ 15.00$

Jar $17 \times 17$ inches. Height of pedestal, 24 inches.

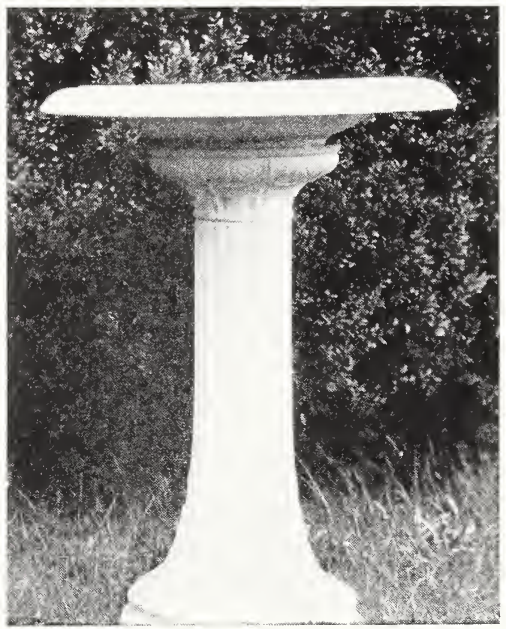

BIRD BATH

Height of pedestal, 31 inches. Diameter of bowl, 21 inches.

No. 39-White Terra Cotta. . . . . . . . . \$ \$10.00

OIL JAR

No. $40-17$-inch.................\$ 6.00 Handle each side.

No. $41-20$-inch ................. 7.50

\section{STRAWBERRY JAR}

No. 42-Six Pockets............... \$10.00 


\section{Beautify Your Home}

\section{USE VIGORO}

\section{Luxuriant Shrubbery-Stately Trees}

Trees and shrubbery, like all other plants, must be fed the right nourishment, the same as human beings, or they become "stunted" and lose the beauty that we so admire. Then, too, undernourished trees and shrubbery are more susceptible to disease and insect -pests.

Scientifically balanced and complete, VIGORO is a specially prepared plant food. It contains all of the elements necessary to grow richly colored flowers, velvety lawns, succulent vegetables, luxuriant shrubbery and healthy trees. Complete directions in every bag.

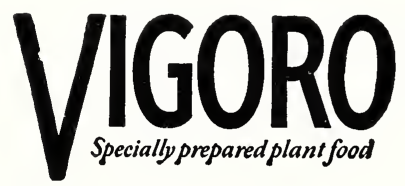

\section{Clean, Odorless, Easy to Apply.}

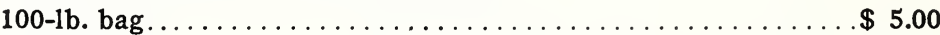

$50-1 b$. bag. ... . . . . . . . . . . . . . . . . . . . . 3.00

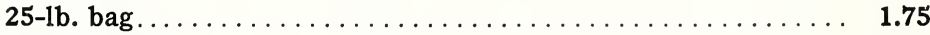

5 -lb. package..........................50

A Swift \& Company Product

\section{Hedge Lawn LAWN GRASS MIXTURE}

This is by far the best mixture offered for the purpose of producing a permanent lawn.

This mixture is prepared from our own formula, and is a careful blending of varieties adapted to producing the thick growth and velvety appearance much desired.

Whether you want to seed a small plot in your yard, or a lawn of more pretentious size, you should use this grass mixture.

For the convenience of our customers, we put this seed up in various sized packages, from a single pound which is sufficient to cover 100 square feet of ground to such quantities as required for seeding large lawns where six bushels of seed are required to the acre.

Per pound.

\section{Turn Garden Refuse into Rich Manure}

Do not destroy garden refuse. It represents more than half the yield of the soil. By the simple ADCO process it can be converted into manure and turned back to nourish that same soil.

Anybody can use ADCO, and every good gardener should use ADCO. Nothing takes the place of manure, and with ADCO you can make quantities of it, rich, odorless and clean.

\section{PRICE}

ADCO, in 150-lb. bags, each . . . . . . \$10.50

(Enough for a heap $10 \mathrm{ft}$. $\times 10 \mathrm{ft}$. $6 \mathrm{ft}$., making about three tons of manure)

ADCO, in 25-lb. bags, each........\$ 2.00

(Enough for 12 wheelbarrow loads of garden waste, making one-half ton of manure)

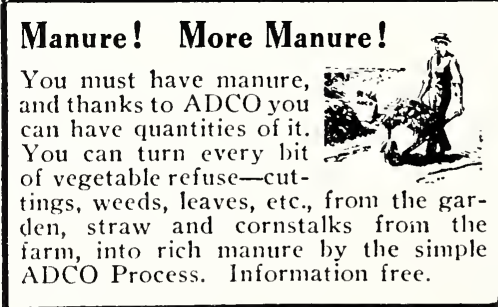

Manure! More Manure!

Yund thanks to ADCO you

can have quantities of it.

You can turn every bit of vegetable refuse-cut-

farm, into rich manure by the simple

ADCO Process. Information free. 


\section{INDEX}

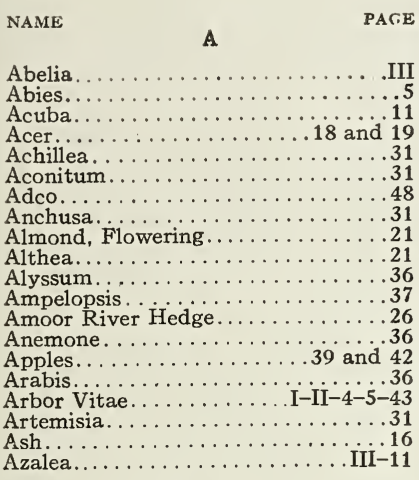

B

Baby Breath................... 32 Baby Evergreens...........

Barberry ..........................

Berries................... 41

Betula.................. 16

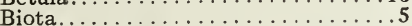

Birch.....................

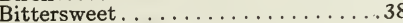

Black Hill Spruce.............. . 9

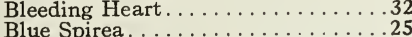

Blue Spirea . . . . . . . . . . . . . . . . .

Boston Ivy . . . . . . . . . . . . 37

Broxwood.

Evergeens. III-11-12-13-14-15

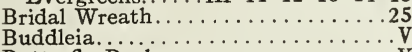

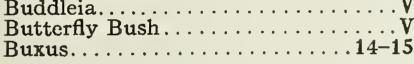

C

California Privet.

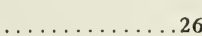

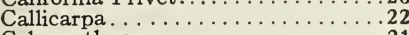

Calycanthus. . . . . . . . . . 21

Campanula .................. 31

Canadian Hemlock...........

Canedensis...................

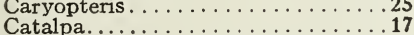

Catalpa.....................

Cedar....................

Cedrus.....................

Cercis Canedensis. . . . . . . . . 20

Cherries, Flowering . . . . . . . . 20

Cherries, Fruiting........... 40

Chinese Elm ................17

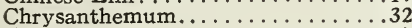

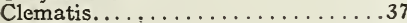

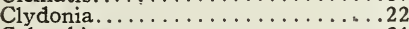

Columbine. . . . . . . .

Coral Berry . . . . . . . . . . . . 21

Cornus. ................. 17

Cotoneaster .................. 12

Crab Apple, Flowering ...........

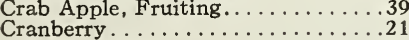

Crepe Myrtie .................

Cupressus.........................

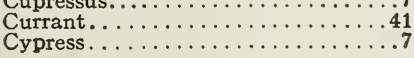

D

Daphne...................13

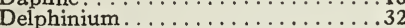

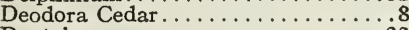

Deutzia...................22

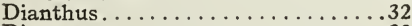

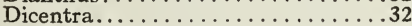

Dogwood ...........................

Douglass Fir . . . . . . . . . . .

$\mathbf{E}$

Eleagnus. . . . . . . . . . . 14

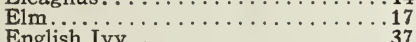

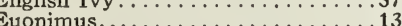

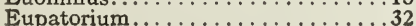

NAME

E

Evergreens. ...... I-II-4-5-6-7-8-9-10

Evergreens, Broad

III-11-12-13-14-15

\section{F}

Fir......

Flowering Almond.

Flowering Cherries.

Forsythia.

Fox Glove.

Fruits. .

$38-39-40-41$

G

Gaillardia.

Garden Ware

German Iris.

Grapes

Grass, Lawn

Grass, Ornamental

Gum.

Gypsophilla.

H

Hedge.

Hemlock

Honeysuckle, Bush

Honeysuckle, Vine

Horse Chestnut.

Hydrangea...

Hypericum.

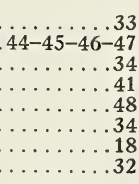

I

Ilex.

Irish Juniper.

Irish Juniper
Ivy . . . . . .

J

Japan Iris

Japanese Azalea.

Japanese Beauty Berry

Japanese Cherry

Japanese Holly

Japanese Magnolia.

Japanese Quince......

Japanese Snow Ball.

Japanese Spurge.

Japanese Yew.

Japonica.....

Jet Bead.

Judas Tree.

Juniper...

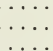

\section{$\mathbf{K}$}

Kalmia.

Kentucky Coffee Tree

Kerria - Write for prices

........

Kudzu Vine.......................

\section{L}

Laurel ....................12

Lawn Benches.................

Lawn Grass...................

Lawson Cypress ................

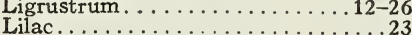

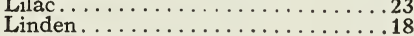

Lombardy Poplar...............

Lonicera................ 23 -38

M

Magnolia $\ldots \ldots \ldots \ldots \ldots \ldots \ldots \ldots 20$

Mahonia Holly ..................

Malus...................22

Maple..................... 19

Mimosa Tree............... 18

Mock Orange. . . . . . . . . . . 24

Mulberry, Weeping. ..............20
NAME

N

PAGE

Nandina Domestica.

New Red Barberry.

Nigra...............

\section{o}

Oak.

Offers, Special

Oriental Plane. .

19

Ornamental Grass.

Pears. .

.40

Perennials. . VI-31-32-33-34-35-36-37 Pfitzer Juniper

Philadelphus.

Phillyrea Decora.

Phlox.

Picea.

Prite for prices.

Platanus.

Plums, Fruiting ........ 19

Plums, Fruiting . . . . . . . . . . . . . .

Pyracantha.

Pyrethrum.

\section{Q}

Quercus

Quince, Flowering

Quince, Fruiting.

\section{$\mathbf{R}$}

Raspberries

Red Bud .

Retinispora.

Rhododendron

$\ldots \ldots \ldots \ldots 41$

H.

S

Salix. . . . . . . . . . . . . . 20

Saucer Magnolia $\ldots \ldots \ldots \ldots \ldots \ldots \ldots \ldots \ldots \ldots \ldots \ldots \ldots$

Sedum. . . . . . . . . . . .

Shrubs . . I-II-III-21-22-23-24-25-26

Small Fruits . . . . . . . . . . . . .

Special Offers.......... I-IV-V $-42-43$

Spirea................IV-V-25-26

Spruce..................II-9

Strawberries. . . . . . . . . . . 41

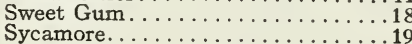

\section{$\mathbf{T}$}

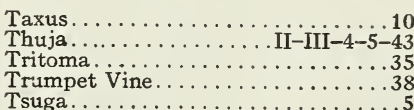

U

Ulmus.................

\section{V}

Veronica................35

Viburnum . F . . . . . . . . . . 21

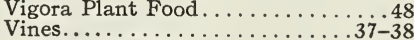

Virginia Creeper.................. 37

\section{W}

Walnut.................

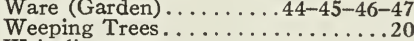
Weigelia................

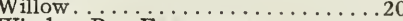

Window Box Evergreens............

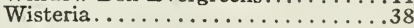

\section{Y}

Yews 


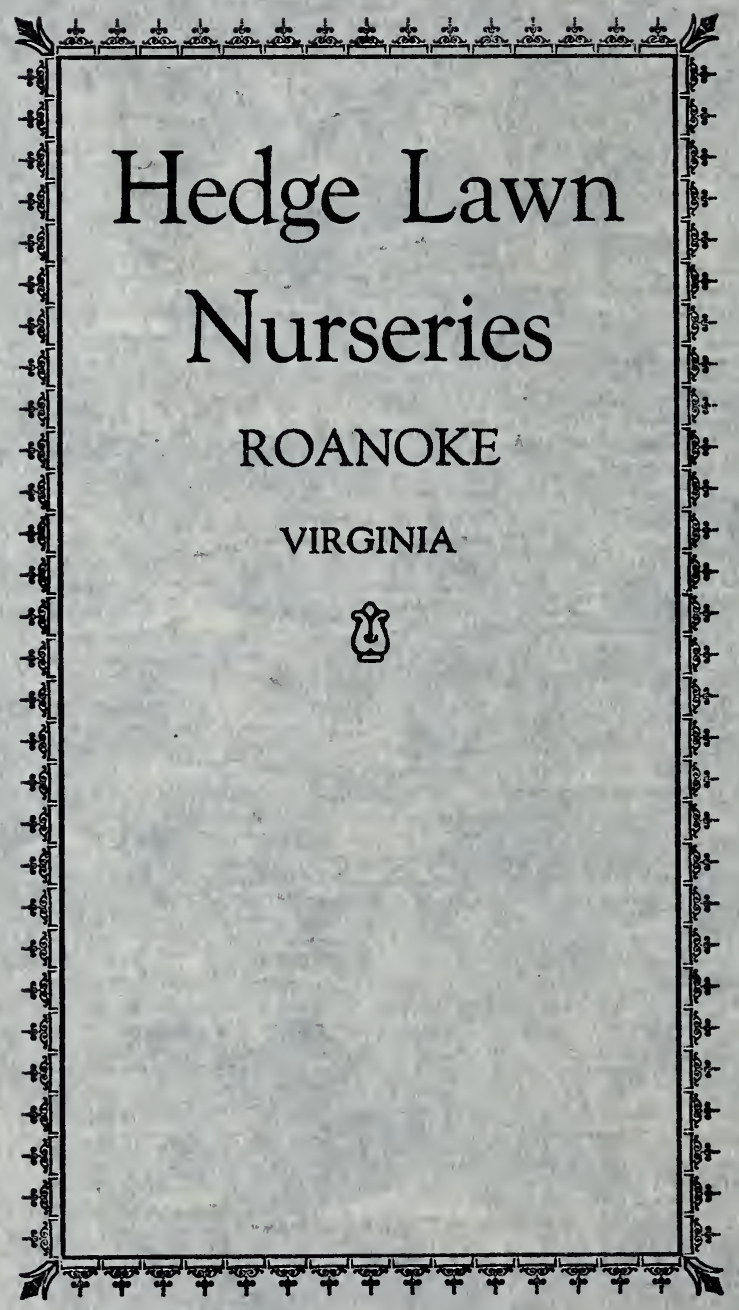

